Papers

of the

East-West

Population Institute

No. 60-E

CURRENT

STUDIES

ON

THE VALUE

OF CHILDREN

\title{
The changing value
of children
in Turkey value
of children
in Turkey value
of children
in Turkey
}

Cigdem Kagitcibasi

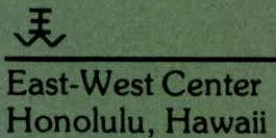

Honolulu, Hawaii 
PAPERS OF THE EAST-WEST POPULATION INSTITUTE, published about eight times a year, facilitate early dissemination of research findings and state-of-the-art essays on the demography of Asia, the Pacific, and the United States. Annual subscription rate, $\$ 12$.

NOTE TO CONTRIBUTORS: The Population Institute considers unsolicited as well as commissioned manuscripts for the Paper Series. Appropriate topics are population estimation and analysis, causes and consequences of demographic behavior, urbanization and population distribution, and population policies and programs. All manuscripts are reviewed. In selecting manuscripts for publication, the Institute considers quality of scholarship and usefulness to public officials and other professionals in the field of population; it also seeks contributions reflecting diverse cultural and disciplinary perspectives on population. The series can accommodate articles not necessarily suited for journals because of unusual length or treatment of subject. All copy must be typed double-spaced. For additional information on manuscript preparation, write to the Publications Officer, East-West Population Institute.

\section{OTHER SERIAL PUBLICATIONS OF THE EAST-WEST POPULATION INSTITUTE:}

Working Papers are circulated for comment and to inform interested colleagues about work in progress at the East-West Population Institute. They are intended to complement evidence of completed work as reflected in Papers of the EastWest Population Institute and the Reprint Series. \$1 per copy.

Reprint Series brings selected articles originating from Institute research but published elsewhere to the attention of population specialists who might not otherwise see them. Single copies available upon request.

Asian and Pacific Census Forum is a quarterly periodical reporting on census, vital registration, and population survey activities in Asia and the Pacific. The Forum contains technical articles on a range of topics related to demographic measurement, and reviews of new publications in the field. Issued in August, November, February, and May. Annual subscription rate, $\$ 5$.

Serial publications except Working Papers are available without charge to libraries serving population specialists and to professionals and scholars in the field of population. Requests describing the nature of the research or program and the intended use of the publications should be addressed to the Publications Office of the Institute.

East-West Population Institute

East-West Center

1777 East-West Road

Honolulu, Hawaii 96848
Director Lee-Jay Cho Publications Officer Sandra E. Ward Editor Robert L. Hearn Production Specialist Lois M. Bender Cartography M. Lynne Ford 


\section{CURRENT \\ STUDIES \\ ON \\ THE VALUE OF CHILDREN}

\section{The \\ changing value of children in Turkey}

Cigdem Kagitcibasi

Number 60-E • June 1982

PAPERS OF THE EAST-WEST POPULATION INSTITUTE 
CIGDEM KAGITCIBASI is Professor, Social Sciences Department, at Bogazici University in Istanbul.

\section{Library of Congress Cataloging in Publication Data}

\section{Kağitçibaşi, Çiğdem.}

The changing value of children in Turkey.

(Papers of the East-West Population Institute, ISSN 0732-0531; no. 60-E (June, 1982). Current studies on the value of children)

Bibliography: p.

1. Children-Turkey. 2. Family size-Economic aspects-Turkey. I. Title. II. Series: Papers of the East-West Population Institute ; no. 60-E. III. Series: Papers of the East-West Population Institute. Current studies on the value of children. HQ792.T95K33 $1982 \quad 304.6^{\prime} 34^{\prime} 09561 \quad 82-11343$ 


\section{CONTENTS}

Preface vii

Abstract 1

Methodology 5

Characteristics of respondents 18

Major findings $\quad 31$

Summary and conclusions $\quad 89$

Policy implications $\quad 92$

References 96 


\section{TABLES, FIGURES, AND EXHIBIT}

Tables

1 Planned and attained sample household distributions, by development stratum 11

2 Final sample distributions, by development stratum and sex $\quad 1.2$

3 Sample and population weights, by development stratum and sex 13

4 Occupations of respondents, by sex 21

5 Actual, desired, and ideal numbers of children 23

6 First and second most important life values 24

7 Perceived in dividual efficacy 26

8 Family decision-making, communication, and role sharing 28

9 Women's status within the family, by occupation 30

10 Advantages of having children 34

11 Most important reasons for wanting another child 36

12 Reasons for not wanting fewer than the desired number of children 37

13 Disadvantages of having children 39

14 Most important reasons for not wanting another child 41

15 Advantages of having children, by development stratum 43

16 Advantages of having children, by educational level 45

17 Advantages of having children, by women's work status and occupation 46

18 Advantages of children, by men's occupation 49

19 Reasons for wanting sons, by development stratum 50

20 Reasons for wanting sons, by educational level 51

21 Value factors, by development stratum and rural/urban residence 54

22 Correlation matrix of background, intervening, and dependent variables, including indices: women 56

23 Advantages of children, by parity 59

24 Contributions of daughters and sons to life values considered most important 62 
25 Qualities desired in daughters and sons 63

26 Expectations of help from sons and daughters 66

27 Most and second most important qualities of a child 67

28 Reasons for wanting a son or a daughter 69

29 Value factors, by parity and whether wanting another child 72

30 Partial correlations of values of children and other predictor variables with family-size desires, parity, birth control practice, and son preference: women 76

31 Canonical correlations of values of children and other independent variables with family-size desires, parity, and birth control: women 78

32 Canonical correlation of values of children and other independent variables with family-size desires, parity, and birth control: men 79

33 Multiple regression analysis of VOC indices and other independent variables on parity, birth control, and desired and ideal number of children: women 80

34 Parity and birth control knowledge and practice, by development stratum and rural-urban residence 86

Figures

1 Theoretical model of the Turkish Value of Children Study 6

2 Three metropolitan centers and provincial centers where interviews were conducted: Turkey 16

Exhibit

Metropolitan cities and provinces where interviews were conducted, by stratum 15 


\section{PREFACE}

This report presents the basic findings from the Value of Children (VOC) Study in Turkey. It is a summary version, in English, of the more comprehensive volume in Turkish entitled, in translation, Value of the Child: Values and Fertility in Tur$k e y$. The study is part of the nine-country comparative VOC project, designed to study motivations underlying childbearing and how these motivations are related, on one hand, to background social-structural-demographic factors and, on the other, to fertility attitudes and behavior. The project is described in the Editor's Foreword to the first report in this series (Paper 60-A), which also identifies other investigators involved in the project and the funding sources. A more detailed description of the Turkish portion of the project is provided in the present report.

Many people both in Turkey and abroad contributed in significant ways to the Turkish VOC Study. My biggest debt is to James T. Fawcett, colleague and friend, who initiated and coordinated the project through its two phases. As this has been a truly collaborative study in respect to design, methodology, and analysis, a great deal of credit goes to other country investigators, especially to Lois Hoffman and to Rodolfo Bulatao, who was the project coordinator in the final phase.

It is impossible to mention individually about 100 personsfield interviewers, team leaders, and supervisors, mostly students at Bogazici University - whose dedicated work made this study possible. A special debt of gratitude is due to all of them. The respondents, numbering more than 2,300 , graciously provided their time, interest, and hospitality. It is to be hoped that benefits from this study may accrue to them and to their children in the years to come. 
A number of colleagues worked on the project as research associates at various times, in particular Ayse Oncu, Deniz Kandiyoti, and Mehmet Odekon. Yilmaz Esmer, who joined the project at its final phase, helped greatly in analyzing the data and bringing the study to its completion. I am indebted to all of them. My students who worked as research assistants at various times, especially Ercan Alp, Hale Bolak, and Iris Segikyan, who worked the longest, and also Ali Munif Seden, Zeynep Catto, and Meral Baruh, contributed greatly to the project. Without the support of all these people-friends, colleagues, studentsthe study could not have been done.

Bogazici University, the Turkish State Planning Organization, the State Institute of Statistics, and the Turkish Ministry of Health and Welfare all endorsed the study and provided institutional support to it. I appreciate their help.

Financial support for the Turkish VOC Study was provided by the International Development Research Centre. Special thanks are due to the Centre and to Alan Simmons for his personal interest and support. The East-West Center, in addition to serving as the initiating institution for the project, provided financial support for various activities of the cross-cultural study, including the publication of this report in the Current Studies on the Value of Children series, with the expert editing of Sandra Ward; for all this I am grateful.

Cigdem Kagitcibasi

Istanbul, September 1981 
ABSTRACT The Turkish Value of Children (VOC) Study was part of a nine-country cross-cultural research project designed to answer the question "Why do people want children?" The study investigated social and psychological as well as socioeconomic and demographic determinants of fertility. The main objective of the study was to increase understanding of the place and role of children in the Turkish family and society.

Values associated with children were conceptualized as intervening between the antecedent socioeconomic and demographic variables and consequent fertility variables. The value of children was conceptualized as the sum of psychological, social, and economic benefits and costs that parents derive from having children.

Guided by this conceptual framework, the Turkish study employed a nationally representative sample of 2,305 married respondents 1,762 females and 543 males), who were interviewed at length. The results shed light not only on the value of children to Turkish parents, but also on the psychodynamics of the Turkish family, in particular sex roles and role sharing, decision making, and communication between spouses.

The study revealed significant and consistent interrelations among the socioeconomic background variables, values of children, and fertility, pointing to the key role of the value of children in explaining fertility. Analysis of the cross-sectional data suggested that, with socioeconomic development and especially with increased education, children's economic value decreases whereas their psychological value increases. As a child's economic value, however, is the same regardless of the number of children in a family, whereas the psychological value of children is negatively associated with parity, the decline in children's economic value and increase in their psychological value with development imply lowered fertility (even though their total value, in quantitative terms, may not change). In other words, the findings imply that fertility decreases with development because economic and psychological values of children are differentially affected by development and are differentially related to family-size preferences. Correlational and regression analysis also revealed that where children's economic value assumed importance, son preference was prevalent, women's status in the family was low, the old-age security value of children was great, and fertility was high. 
The paper discusses the theoretical and policy implications of the findings.

Children have always been such an integral part of the family that it does not usually occur to people to ask what their "value" is. Couples just have children in the natural course of events, and in the opinion of many people a family without children is not complete.

With the recent concern about population growth, however, this question about the value of children is assuming great significance to social scientists and policy-makers. Understanding the motivational dynamics underlying childbearing may assist at tempts to modify those motivations and consequent fertility behavior, with the eventual goal of reducing population growth. Indeed, many population policies aim at changing these childbearing motivations.

In an attempt to understand motivations for childbearing, a group of social scientists undertook a cross-cultural comparative survey exploring the value of children (VOC). The study aimed to answer the basic question"Why do people want children?"

The VOC project developed out of a conference on Assessment of the Satisfactions and Costs of Children, held at the East-West Center in Honolulu, Hawaii, in April 1972 (Fawcett, 1972). In the first phase of the project an exploratory comparative study was carried out in Japan, the Republic of Korea, the Philippines, Taiwan, Thailand, and the State of Hawaii (Arnold et al., 1975; Bulatao, 1975; Arnold and Fawcett, 1975; Buripakdi, 1977; Wu, 1977; Lee, 1979; Iritani, 1979). Turkey joined the project in 1974 with an exploratory pilot study (Kagitcibasi, 1975b).

Based on the experience and findings of the first phase and the pilot study done in Turkey, the second and the main phase of the VOC project started in 1975. Participating countries were Indonesia, the Republic of Korea, the Philippines, Singapore, Taiwan, Turkey, the United States, and subsequently the Federal Republic of Germany. ${ }^{1}$

1 Principal investigators were Russell K. Darroch and Masri Singarimbun (Indonesia); Sung Jin Lee (Korea); Rodolfo A. Bulatao (Philippines); Bet ty Jamie Chung, Eddie Kuo, and Peter S.J. Chen (Singapore); Tom T.H. Sun ahd TsongShien Wu (Taiwan); Chalio Buripakdi, Nibhon Debavalya, and the late Visid Prachuabmoh (Thailand); Cigdem Kagitcibasi (Turkey); Lois W. Hoffman, James T. Fawcett, and Fred Arnold (United States); and Esther R. Mechler, Brian R. Flay, and Andrejs Urdze (Germany). Research in the various countries 
In each country (except West Germany) a sample of about 1,500 to 3,000 married respondents was surveyed. At present all of the national data have been analyzed, and cross-national analyses are underway (e.g., Bulatao, 1979a, 1979b; Kagitcibasi, 1979, 1982a; Bulatao and Arnold, 1977).

The main theoretical objectives of the Turkish VOC Study were to further our understanding of the value and role of the child in the Turkish family and Turkish society by delineating the effects of social, economic, and demographic characteristics of couples on the value of children, and in turn the influence of children's value on couples' fertility attitudes and behavior. The study was expected to have policy relevance for family planning communication programs and population policy-makers.

The value of children for parents, the family, and the society is of great theoretical and practical significance. An understanding of the satisfactions that parents find in children is a key to developing insights into family dynamics, sex roles, social norms, beliefs, attitudes, and fertility behavior. Because the value of children or of a next child may be a motivation for childbearing, it should assume an important role in any model of fertility.

The concept of the value of children has entered into various conceptualizations of fertility motivation in the past several decades. A focus on the value of children has been noticeable especially in economic and social-psychological approaches to fertility research. The concept has been used implicitly or explicitly in other approaches as well, and its development has been influenced by research results.

Various theoretical orientations have helped shape the concept of the value of children. They have included the historical-demographic orientation finding expression in the theory of demographic transition; the social-structural orientation as used in sociological and anthropological studies; the economic orientation, and especially microeconomic theory; and the social-psychological orientation. These orientations have been presented, for example, in Fawcett (1977:94-97) and Kagitcibasi and Esmer (1980).

was supported by International Development Research Centre (IDRC), the Ford Foundation, the Rockefeller Foundation, the Research Institute for the Study of Man, the U.S. National Institute for Child Health and Human Development, the East-West Center, and the Smithsonian Institution. The Turkish VOC Study was supported by the IDRC. 
Within the social-psychological orientation, the value of children to parents assumes importance because of the motivational dynamics underlying fertility behavior. As the needs of individuals are emphasized, needs satisfied by children come to the fore. A theoretical framework for the social-psychological approach has been provided by Fawcett (1972), Hoffman and Hoffman (1973), and Berelson (1973). The VOC Study is based mainly on the Hoffman and Hoffman scheme, and through it further theoretical development has taken place (Arnold et al., 1975; Fawcett, 1976; Kagitcibasi, 1979, 1981b; Bulatao, 1979a, 1979b).

In the VOC Study, with its social-psychological orientation, the value of children is a perceived value; it is subjectively defined. Thus the value of a child (economic or otherwise), social expectations and pressures, etc., are all assessed as perceived and self-reported by the subjects. The assumption is that these variables exert an influence on individual behavior only if they are perceived by the individual and thus have a meaning for her or him. It is also assumed that a value attributed to a child by the parent corresponds to an objective contribution of the child to the parent and the family, though the correspondence is not of central importance in the social-psychological approach. Accordingly, a different assessment of the value of children is used here from that derived by calculating wealth flows from children to parents or using other objective measurements of children's contributions to the family. Whether attributed or perceived value of children can replace more objective measures of their value and whether the perceived value has more explanatory power are empirical questions that need to be answered. Whether perceived or attributed value can be validly assessed is a related, methodological question (Fawcett, 1977:97). In the VOC Study much attention was given to the operationalization and measurement of the value of children in order to achieve valid and reliable results.

The concept of the value of children is treated in the VOC Study as a key causal variable that is postulated to change with social change and to affect fertility accordingly. It is conceptualized in functional terms as the sum of perceived benefits minus costs that parents obtain from having children. These benefits and costs are viewed as complex variables having at least three dimensions-psychological, social, and economic. They are further conceptualized as intervening between antecedent background and social-psychological variables and 
consequent fertility-related behavior. Figure 1 presents the theoretical model of the Turkish VOC Study. It is based on the model developed in the course of the first phase of the VOC Study (Amold et al., 1975:8) and is similar to it.

The model is an implicit decision-making model, for there is an underlying assumption that advantages and disadvantages are weighed against each other. Uncontrolled variation may enter the model, however, derived from unconscious needs, ambivalent feelings, situational demands, habits, and spontaneous emotional behavior. Such variation (indicated by the element of uncertainty in Figure 1) may interfere with prediction based on a completely rational decision-making model. But alternatives do not have to be rational in order to enter into a decision-making process, and not to have a child requires an active choice. Thus, even though rational, explicit decision-making such as seen, for example, in problem-solving behavior may be lacking, implicit decision-making is assumed in the model. The VOC Study has attempted to find out the extent to which this decision-making model and its underlying cost-benefit approach are explanatory and predictive for different populations and subpopulations.

As shown in Figure 1, the number of children a couple actually has is conceptualized as both an independent background variable (parity) and a dependent variable. (It would never appear as both, however, in the same multivariate analysis.) This aspect of fertility is explained in the section on major findings.

\section{METHODOLOGY}

\section{The pilot study}

The Turkish VOC project started with a pilot study in 1974. As Turkey had not participated in the first, exploratory phase of the VOC Study, a sizable pilot study involving pretesting of the questionnaire was conducted in preparation for the nationwide study.

The pilot study sample consisted of approximately equal numbers of urban middle socioeconomic status (SES), urban lower SES, and rural respondents, two-thirds of whom were female and one-third male, totaling 189. The pilot study field interviews were carried out during August 1974.

The questionnaire used in the pilot study was developed from the core questionnaire used in the first phase of the VOC Study. It elicited 
FIGURE 1 Theoretical model of the Turkish Value of Children Study

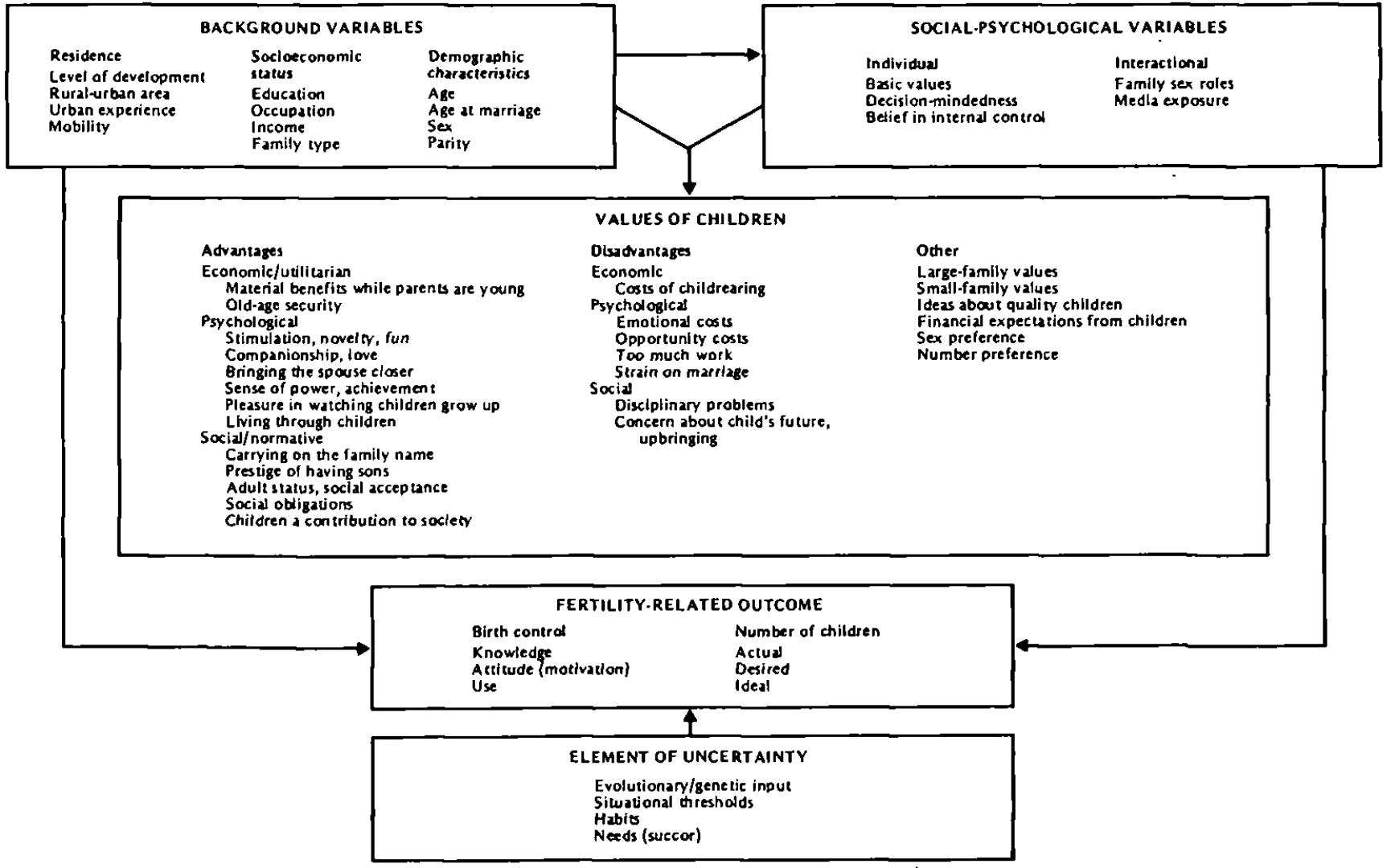


information on respondents' parity, additional children wanted, and ideal number of children; values attributed to children (happiness and companionship, incentive and accomplishment, sibling companionship, family cohesion and continuity, play and fun, economic help); birth control knowledge and experience; costs of rearing children; education; employment; decision contexts; and background of respondents.

The main aim of the pilot study was to test the validity of the questionnaire for use in Turkey. Findings from the pilot study provided insights into the relationships among the various factors assessed by the questionnaire, leading to the conceptual development of the second phase of the Turkish study. A rich variety of values (both positive and negative) was attributed to children by respondents, and significant differences emerged among respondents according to their rural-urban residence, social class, and sex. Findings from the pilot study are described else where (Kagitcibasi, 1975b, 1976). On the basis of the field experience and analysis of the questionnaire items and scales, the pilot questionnaire was revised for the nationwide survey.

\section{The national survey}

The national survey was carried out in August and September 1975. A nationally representative sample of 2,305 Turkish adults, of whom three-quarters were women, was interviewed at length by trained interviewers. Questions were both open-ended, to permit respondents to express their opinions in their own words, and structured, to tap values and attitudes that might be difficult for respondents to articulate. Many of the structured questions formed scales. Responses were content-analyzed, coded, and subjected to correlational, factor, and regression analysis. ${ }^{2}$

\section{Questionnaire}

The Turkish VOC questionnaire, which was developed from the collaboratively designed core questionnaire used in all of the participating countries, was translated into Turkish with special care so that the Turkish respondents would interpret the questions correctly. Back translations were performed by the principal investigator and two

2 Various aspects of the VOC research methodology are described in Technical Notes issued by the East-West Population Institute. Of special relevance to the present discussion are Technical Notes 4, "Sampling Procedures"; 5, "The Questionnaire"; and 6, "Survey Procedures." 
assistants fluent in English. The functional equivalence of the English and the Turkish questionnaires was thereby established.

Two separate forms of the questionnaire were developed for couples with and without children. Both contained 103 questions. Topics covered were parity, desired number of children, ideal number of children, values and costs of children, number and sex preferences, ideas about "quality" children, general values, financial expectations from children, birth control (attitudes, knowledge, and use), decision context (belief in internal versus external control of reinforcement), sex roles, education and occupation, mobility, mass media exposure, family type, and income. ${ }^{3}$ There were also a few country-specific questions dealing with childcare.

\section{Interviewer Selection and Training}

Interviewers were university students selected from among a large number of candidates by a screening committee. The committee relied on individual interviews and background information about the candidates for this purpose. Criteria for selection were age, sex, field of study, grade-point average, previous interviewing experience, previous village and small town living experience, appearance, voice, and manner of talking. About three-fourths of the interviewers were chosen from among women candidates to interview women respondents, who formed three-fourths of the sample. Older interviewers were preferred in order not to have too great an age difference between interviewers and respondents. In general, upper-level undergraduate students and graduate students in the social sciences and humanities who had some experience in interviewing people or rural experience and who had a pleasant appearance and manner were selected. Eighty-five interviewers were recruited.

Interviewers received training during ten days in early August 1975. Fifteen trainees who were most competent were selected to be team leaders. The interviewers and team leaders were assigned to 15 groups of six persons each.

The training was highly concentrated. Although some of the trainees had had interviewing experience prior to the training session,

3 The core questionnaire is described in the editor's Foreword to the first report in this series (Bulatao, 1979:xii-xiii) and in Technical Note No. 5 issued by the East-West Population Institute. 
the content of the VOC questionnaire and the duration of the interview posed problems rare in a less complicated survey.

In the training sessions, trainees were given detailed information about the project, including the nature of the research, the aims of the VOC Study, and its expected usefulness to policy-makers. A great deal of interest was thus generated in the project, which increased the interviewers' commitment to their work.

The trainees learned about interview techniques from three interviewer training manuals. One of these contained general information about interview techniques; the second dealt with more specific issues related to the VOC questionnaire, based on the pretest experience; and the third contained question-by-question interview instructions. Training was done through mock interviews, actual interviews, small group discussions, and observation, all closely supervised by experienced trainers. Emphasis was placed on probing techniques and creating a situation most conducive for a successful interview.

During the training, a sampling expert from the Turkish State Institute of Statistics gave instruction on the sampling scheme, directions for locating the subjects to be interviewed, and advice on handling such problems as nonresponse, change of address, and sampling in remote rural areas. The maps prepared by the State Institute of Statistics were based on a cluster-block technique which gave the interviewers a beginning point and showed how to proceed from there.

\section{Sampling Procedure}

The Turkish sample consisted of 2,305 respondents of whom 1,762 were women and 543 were men. To draw the sample, the VOC survey used multistage stratified random sampling, in which stratification was done by level of socioeconomic development.

The method of sample selection was based on that used in the Turkish Demographic Survey (TDS), which had been developed by the Turkish State Institute of Statistics in collaboration with the POPLAB program of the University of North Carolina and is described in Cavdar (1975). Cavdar served as sampling consultant in the present survey.

The 67 provinces of Turkey were first divided into three strata according to their level of socioeconomic development: (1) most developed, (2) intermediate, and (3) least developed. The three largest cities-Istanbul, Ankara, and Izmir-were treated as a fourth, metropolitan stratum, considered to have the highest level of development. 
The grouping of provinces was based on the geometric mean of ranks on various social and economic variables. Provinces with a mean rank of between 1 and 20 were considered most developed, those with a mean between 21 and 40 were considered intermediate, and those with a mean above 40 were considered least developed.

Within each stratum except the fourth, all urban and rural places were classified into five substrata according to the following population ranges: (1) 100,001 or more inhabitants, (2) 50,001 to 100,000 , (3) 10,001 to 50,000, (4) 2,001 to 10,000 , and (5) 2,000 or fewer (the last being rural areas or villages). Within these substrata, urban and rural places were listed in order of population size. Within the fourth stratum, the three largest cities served as separate substrata. There were therefore 18 substrata in all. From each substratum except the three metropolitan areas, urban and rural places were selected systematically from the cumulated population distribution.

Places with populations of more than 10,000 (including the three largest cities) were next divided into wards (mahalles). The wards were stratified in a manner similar to the provinces and a sample of wards for each sampled place was chosen. The selected wards were mapped and a list of their households prepared. Each ward was subdivided into blocks of about 50 households or about 250 people. One block was selected randomly from each ward. Places with populations of between 2,001 and 10,000 were subdivided into blocks of similar size, after also being mapped. A variable number of blocks was then chosen. Rural places were subdivided into villages rather than blocks, and a variable number of villages was chosen. Within each of the selected blocks or villages, 20 households were systematically selected.

The sample selection had, thus, up to four levels: (1) urban and rural places, (2) wards (in large urban places only), (3) blocks or vil- . lages, and (4) households.

For the TDS, the sampling fractions were $1 / 100,000$ for urban areas and $1 / 250,000$ for rural areas. For the VOC survey, the sampling fractions were meant to be:

$$
f_{m}=\frac{480}{2.400} \times \frac{n_{m}}{N_{m}} \text { for metropolitan areas, }
$$

where $n_{m}$ is the 1973 population in the sample blocks and $N_{m}$ is the total metropolitan population:

$$
f_{u}=\frac{1.016}{6.350} \times \frac{n_{u}}{N_{u}} \text { for urban areas, }
$$


where $n_{u}$ and $N_{u}$ are similarly defined for urban areas; and

$$
f_{r}=\frac{1}{\lambda} \times \frac{n_{r}}{N_{r}} \text { for rural areas, }
$$

where $n_{r}$ and $N_{r}$ again are similarly defined and $\lambda$ is the average selection interval for rural substrata.

The planned and attained distributions of the sample households are given in Table 1. The final distributions by stratum and sex are presented in Table 2.

We compared the distribution of completed interviews with 1975 census figures and devised weights to make the sample and census correspond. The sample weights in Table 3 are applied if it is desired to keep the total sample size unchanged; the population weights in Table 3 bring the figures up to the population totals.

The Exhibit lists the 35 provinces and three metropolitan cities where interviewing was done. The locations of the provincial centers are indicated in Figure 2.

TABLE 1 Planned and attained sample household distributions, by development stratum

\begin{tabular}{lrrrrr}
\hline & $\begin{array}{l}\text { Three } \\
\text { largest } \\
\text { cities }\end{array}$ & $\begin{array}{l}\text { Most } \\
\text { developed } \\
\text { provinces }\end{array}$ & $\begin{array}{l}\text { Inter- } \\
\text { mediate } \\
\text { provinces }\end{array}$ & $\begin{array}{l}\text { Least } \\
\text { popeloped } \\
\text { provinces }\end{array}$ & Total \\
\hline Planned distribution & & & & & \\
$\quad$ Metropolitan & 480 & 0 & 0 & 0 & 480 \\
100,001 or more & 0 & 136 & 64 & 40 & 240 \\
$50,001-100,000$ & 0 & 56 & 40 & 16 & 112 \\
$10,001-50,000$ & 0 & 104 & 112 & 112 & 328 \\
$2,001-10,000$ & 0 & 88 & 144 & 104 & 336 \\
Rural (2,000 or fewer) & 0 & 110 & 140 & 135 & 385 \\
Total & 480 & 494 & 500 & 407 & 1,881 \\
& & & & & \\
Attained distribution & & & & & \\
Metropolitan & 447 & 0 & 0 & 0 & 447 \\
100,001 or more & 0 & 99 & 77 & 35 & 211 \\
$50,001-100,000$ & 0 & 106 & 41 & 20 & 167 \\
$10,001-50,000$ & 0 & 94 & 120 & 91 & 305 \\
$2,001-10,000$ & 0 & 95 & 143 & 101 & 339 \\
Rural (2,000 or fewer) & 0 & 127 & 139 & 73 & 339 \\
Total & 447 & 521 & 520 & 320 & 1,808 \\
\hline
\end{tabular}


TABLE 2 Final sample distributions, by development stratum and sex

\begin{tabular}{|c|c|c|c|c|c|c|c|}
\hline \multirow[b]{2}{*}{ Stratum and sex } & \multicolumn{7}{|l|}{ Population } \\
\hline & Metropolitan & $\begin{array}{l}100,001 \\
\text { or more }\end{array}$ & $\begin{array}{l}50,001- \\
100,000\end{array}$ & $\begin{array}{l}10,001- \\
50,000\end{array}$ & $\begin{array}{l}2,001- \\
10,000\end{array}$ & $\begin{array}{l}\text { Rural }(2,000 \\
\text { or fewer) }\end{array}$ & Total \\
\hline \multicolumn{8}{|c|}{ Three largest cities } \\
\hline Women & 444 & 0 & 0 & 0 & 0 & 0 & 444 \\
\hline Men & 121 & 0 & 0 & 0 & 0 & 0 & 121 \\
\hline \multicolumn{8}{|c|}{ Most developed provinces } \\
\hline Women & 0 & 98 & 100 & 91 & 95 & 118 & 502 \\
\hline Men & 0 & 31 & 31 & 31 & 28 & 33 & 154 \\
\hline \multicolumn{8}{|c|}{ Intermediate provinces } \\
\hline Women & 0 & 75 & 40 & 119 & 136 & 132 & 502 \\
\hline Men & 0 & 24 & 12 & 38 & 46 & 45 & 165 \\
\hline \multicolumn{8}{|c|}{ Least developed provinces } \\
\hline Women & 0 & 35 & 20 & 89 & 99 & 71 & 314 \\
\hline Men & 0 & 10 & 7 & 27 & 35 & 24 & 103 \\
\hline \multicolumn{8}{|l|}{ All strata } \\
\hline Women & 444 & 208 & 160 & 299 & 330 & 321 & 1,762 \\
\hline Men & 121 & 65 & 50 & 96 & 109 & 102 & 543 \\
\hline Both sexes & 565 & 273 & 210 & 395 & 439 & 423 & 2,305 \\
\hline
\end{tabular}


TABLE 3 Sample and population weights, by development stratum and sex

\begin{tabular}{|c|c|c|c|c|c|c|}
\hline \multirow[b]{2}{*}{$\underline{\text { Sample or population weight }}$} & \multicolumn{6}{|l|}{ Population } \\
\hline & Metropolitan & $\begin{array}{l}100,001 \\
\text { or more }\end{array}$ & $\begin{array}{l}50,001- \\
100,000 \\
\end{array}$ & $\begin{array}{l}10,001- \\
50,000\end{array}$ & $\begin{array}{l}2,001- \\
10,000 \\
\end{array}$ & $\begin{array}{l}2,000 \\
\text { or fewer }\end{array}$ \\
\hline \multicolumn{7}{|l|}{ SAMPLE WEIGHT } \\
\hline $\begin{array}{l}\text { Most developed provinces } \\
\text { Female } \\
\text { Male }\end{array}$ & & $\begin{array}{l}.8303 \\
.8038\end{array}$ & $\begin{array}{l}.3776 \\
.3507\end{array}$ & $\begin{array}{l}.6792 \\
.6552\end{array}$ & $\begin{array}{l}.6594 \\
.6550\end{array}$ & $\begin{array}{l}1.9473 \\
2.1346\end{array}$ \\
\hline $\begin{array}{l}\text { Intermediate provinces } \\
\text { Female } \\
\text { Male }\end{array}$ & & $\begin{array}{l}.4959 \\
.4620\end{array}$ & $\begin{array}{l}.5788 \\
.5390\end{array}$ & $\begin{array}{l}.5385 \\
.5034\end{array}$ & $\begin{array}{l}.6394 \\
.6144\end{array}$ & $\begin{array}{l}2.1726 \\
2.0270\end{array}$ \\
\hline $\begin{array}{l}\text { Least developed provinces } \\
\text { Female } \\
\text { Male }\end{array}$ & & $\begin{array}{l}.8339 \\
.8931\end{array}$ & $\begin{array}{l}.4160 \\
.3639\end{array}$ & $\begin{array}{l}.8856 \\
.8845\end{array}$ & $\begin{array}{l}.7546 \\
.5427\end{array}$ & $\begin{array}{l}5.3368 \\
5.0431\end{array}$ \\
\hline $\begin{array}{l}\text { Cities } \\
\text { Istanbul } \\
\begin{array}{l}\text { Female } \\
\text { Male }\end{array}\end{array}$ & $\begin{array}{l}.4682 \\
.6033\end{array}$ & & & & & \\
\hline $\begin{array}{l}\text { Ankara } \\
\text { Female } \\
\text { Male }\end{array}$ & $\begin{array}{l}.5386 \\
.5104\end{array}$ & & & & & \\
\hline $\begin{array}{l}\text { Izmir } \\
\text { Female } \\
\text { Male }\end{array}$ & $\begin{array}{l}.5408 \\
.4807\end{array}$ & & & & & \\
\hline
\end{tabular}




\begin{tabular}{|c|c|c|c|c|c|c|}
\hline \multirow[b]{2}{*}{ Sample or population weight } & \multicolumn{6}{|l|}{ Population } \\
\hline & Metropolitan & $\begin{array}{l}100,001 \\
\text { or more } \\
\end{array}$ & $\begin{array}{l}50,001- \\
100,000 \\
\end{array}$ & $\begin{array}{l}10,001- \\
50,000 \\
\end{array}$ & $\begin{array}{l}2,001- \\
10,000 \\
\end{array}$ & $\begin{array}{l}2,000 \\
\text { or fewer }\end{array}$ \\
\hline \multicolumn{7}{|l|}{ POPULATION WEIGHT } \\
\hline $\begin{array}{l}\text { Most developed provinces } \\
\text { Female } \\
\text { Male }\end{array}$ & & $\begin{array}{r}8,053.7 \\
25,455.8\end{array}$ & $\begin{array}{r}3,662.5 \\
11,104.7\end{array}$ & $\begin{array}{r}6,588.4 \\
20,748.0\end{array}$ & $\begin{array}{r}6,400.5 \\
20,741.4\end{array}$ & $\begin{array}{l}18,888.9 \\
67,598.7\end{array}$ \\
\hline $\begin{array}{l}\text { Intermediate provinces } \\
\text { Female } \\
\text { Male }\end{array}$ & & $\begin{array}{r}4,810.3 \\
14,632.0\end{array}$ & $\begin{array}{r}5,614.8 \\
17,068.8\end{array}$ & $\begin{array}{r}5,223.9 \\
15,942.1\end{array}$ & $\begin{array}{r}6,202.5 \\
19,457.8\end{array}$ & $\begin{array}{l}21,073.9 \\
64,190.7\end{array}$ \\
\hline $\begin{array}{l}\text { Least developed provinces } \\
\text { Female } \\
\text { Male }\end{array}$ & & $\begin{array}{r}8,088.9 \\
28,283.0\end{array}$ & $\begin{array}{r}4,035.3 \\
11,524.7\end{array}$ & $\begin{array}{r}8,590.7 \\
28,010.5\end{array}$ & $\begin{array}{r}7,319.2 \\
17,187.2\end{array}$ & $\begin{array}{r}51,767.3 \\
159,707.6\end{array}$ \\
\hline $\begin{array}{l}\text { Cities } \\
\text { Istanbul } \\
\text { Female } \\
\text { Male }\end{array}$ & $\begin{array}{r}4,541.8 \\
19,105.4\end{array}$ & . & - & & & \\
\hline $\begin{array}{l}\text { Ankara } \\
\text { Female } \\
\text { Male }\end{array}$ & $\begin{array}{r}5,224.1 \\
16,162.8\end{array}$ & & & & & \\
\hline $\begin{array}{l}\text { Izmir } \\
\text { Female } \\
\text { Male }\end{array}$ & $\begin{array}{r}5,245.4 \\
15,224.1\end{array}$ & & & & & \\
\hline
\end{tabular}


EXHIBIT Metropolitan cities and provinces where interviews were conducted, by stratum

\begin{tabular}{llll}
\hline & Provinces & & \\
\cline { 2 - 4 } Metropolitan cities & Developed & Intermediate & Least developed \\
\hline \multirow{2}{*}{$\begin{array}{llll}\text { Istankara } \\
\text { Izmir }\end{array}$} & Adana & Amasya & Afyon \\
& Adapazari & Bolu & Bilecik \\
& Antakya & Burdur & Corum \\
& Antalya & Denizli & Diyarbakir \\
& Aydin & Elazig & Giresun \\
& Balikesir & Erzurum & Kars \\
& Bursa & Isparta & Nigde \\
& Eskisehir & Konya & Sivas \\
& Gaziantep & Kutahya & Tunceli \\
& Mersin & Malatya & Urfa \\
& Zonguldak & Manisa & Van \\
& Mugla & \\
& Nevsehir & \\
& Rize & \\
& Samsun & \\
& & Trabzon & \\
\hline
\end{tabular}

\section{Field Work}

Interviewer groups were in the field for 15 to 20 work days. Field work was completed by the end of the first week of September 1975. Each group consisted of five interviewers (four women and one man) and a team leader (male), who also did some interviewing. All groups except those in the metropolitan cities also had a field supervisor (male). Field supervisors were employees of the State Institute of Statistics and were familiar with the areas surveyed. Thus, they were responsible for locating areas and respondents and for making necessary local contacts. (They had been prepared for this task by a one-day special training session.) The help of "local recorders" was also obtained. These were local people regularly hired by the State Institute of Statistics to record births and deaths in their regions.

In each sampling block, a screening operation was necessary to locate eligible couples. Eligible couples had to have been living together for at least the previous six months. This criterion disqualified some families in which the man was away in a city or another country and 


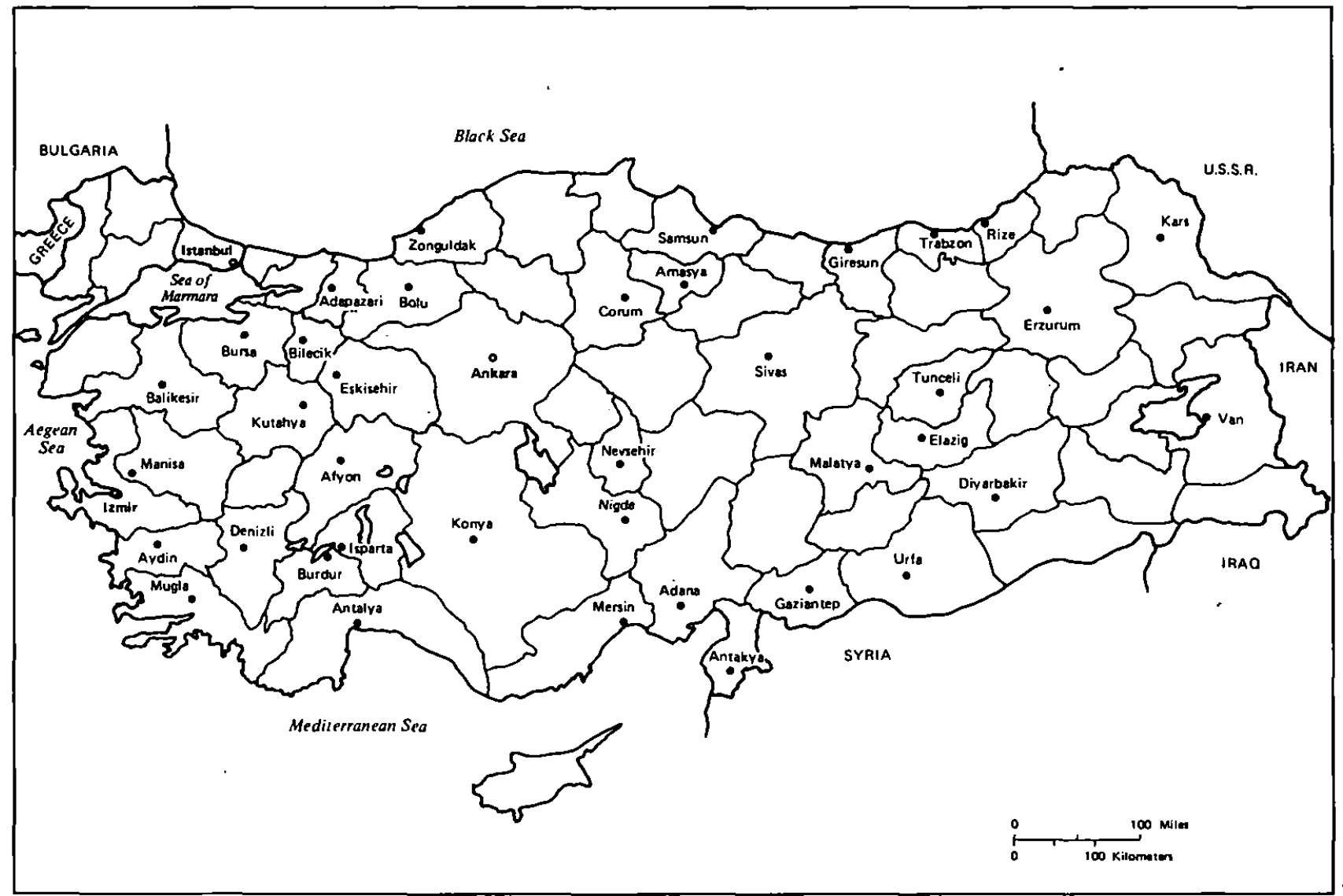


had not been back recently to visit. Another eligibility criterion was that the wife be under age 40 .

In each block or village, 20 households were systematically selected. Selection was based on district and block maps provided by the Turkish State Institute of Statistics. A random starting point was chosen and every $n$th house (the number depending upon the total number of houses in the block) was approached. In rural villages the first 20 houses next to the house chosen as the random starting point were selected for interviews. (Small villages might not have had many more than 20 households.) Substitution was allowed for households where interviewing could not be done because of refusals, ineligibility, or failure to make contact with the occupants after two attempts. Substitutions were selected in the same systematic way as the original 20 households.

Five or six couples were to be interviewed from each block. Husband and wife were always interviewed separately, in some cases simultaneously by different interviewers and in others on different occasions. The spouse interviewed first was asked not to discuss the session until the other spouse had been interviewed. In addition to the couples, about 15 married women were interviewed in each block. In some blocks a few married men were also interviewed. The quota of five couples and 15 married women could not be reached in a few blocks.

Interviews lasted from 45 minutes to three hours, the mean length being an hour and a quarter. Some respondents thought the questionnaire was too long. Rapport between the interviewer and the respondent, length of the interview, the amount of time the respondent was able to spare for the interview, and other situational variables influenced the quality of the answers. There was sometimes a problem of communication between a literate urban interviewer and an illiterate rural peasant, which we had tried to minimize by careful interviewer training.

The interviewer corrected the completed questionnaires, which were reviewed and edited by the team leader in consultation with the interviewer at the end of each day of fieldwork. Revisits were not possible, and therefore a small number of questionnaires had to be discarded because of incompleteness or internal inconsistencies. 
Screening, Relisting, and Coding

At the end of the field interview period, the completed questionnaires were grouped by sampling block and region, and identification numbers were assigned to them. A coding framework was prepared, based on the international VOC codebook and the Turkish pretest codebook.

Coders were drawn from the pool of interviewers. That all the coders had field experience and were familiar with the questionnaires proved to be of great value for coding. Double coding was done and feedback was provided to the coders by the controllers. As double coding was used throughout and as most of the coders, being students, could work only part time, the coding took about four months to complete. Generally, the same two persons coded all the interviews for a particular block.

\section{CHARACTERISTICS OF RESPONDENTS}

\section{Current age and age at marriage}

As a result of the screening criteria, the sample was a young one, the mean age being 28 for females and 34 for males. Slightly over half $(52 \text { percent })^{4}$ of the women respondents had married between the ages of 15 and 17 . Twenty-nine percent were between 18 and 20 years old at first marriage and 16 percent had married either at less than 15 years of age or between 21 and 23 . Only 2 percent had married at ages 24-26 and a mere 1 percent had married at later ages. In contrast, only 11 percent of the husbands had married between ages 15 and 17, 27 percent between ages 18 and 20 , and 23 percent between ages 21 and 23 . The largest proportion ( 37 percent) had married at 24 or older (up to age 42 ).

These figures, indicating earlier age at marriage for women than for men, have significant implications both for fertility and for women's status in Turkey. Early marriage increases the period of exposure to sexual activity for women and contributes to high fertility. Having many children, in turn, is not compatible with women's pursuit of careers outside the home. Furthermore, because age and wisdom are traditionally thought to be associated with one another, a "bride" has a low status in her husband's household, befitting her youth and

4 As national representation was sought in the Turkish VOC Study, proportions of respondents are expressed as weighted percentages. 
ignorance. Accordingly, the age difference between wives and husbands enhances male prestige, and it reinforces sex-role differentiation within the family.

\section{Education}

Educational levels were found to be quite low, especially among female respondents. Forty-six percent of the women and 13 percent of the men had had no formal schooling. Twenty-eight percent of the women and 45 percent of the men were primary school graduates; only 6 percent of the women and 13 percent of the men had received a high school education or more. Mean school years attended were 2.87 years for women and 5.27 years for men.

Urban-rural differences were marked. For men in urban areas the mean number of school years attended was 6.18 , compared with the rural figure of 4.03 , the difference being highly significant $\left(\chi^{2}=51.74\right.$; $p<.001) .{ }^{5}$ The difference is also striking for women, the urban mean being 3.6 school years and the rural being $1.77\left(\chi^{2}=127.63 ; p<.001\right)$. Those who had never attended school constituted 38 percent of women in urban areas and 58 percent in rural areas. The percentages were 10 and 17 , respectively, for men.

The above figures, which are consistent with census data and other research findings (e.g., Tuncer, 1976:106), point to generally low levels of education in Turkey. The strikingly low educational levels of women have obvious implications for the status of women in that society. The marked sex differential in education shows that the situation in Turkey is not very different from that of other Middle Eastern countries (Timur, 1977). The sex differential is higher than in East Asian and Latin American countries of about the same general development level as Turkey, and it is the highest among the VOC countries.

\section{Occupation}

At the time of the interviews, 55 percent of the female respondents were doing some work other than housekeeping. Of those who were working 34.7 percent were family workers, not earning money but contributing to the family income. Seventy percent of the women

5 These $\chi^{2}$ figures were obtained from a 2 (rural-urban) by 15 (education) $\chi^{2}$ matrix. School years were categorized as follows: $0-11$ (finished high school), 13 (attended university), and 15 (finished university). The $N$ values were 1,762 for women and 543 for men. 
interviewed reported they did not earn money; of these 52 percent said they had worked at some time since marriage.

Many Turkish women work hard, especially in rural areas, but do not consider themselves to be working because their work is not remunerated, it is done at home, or it is done at irregular hours. Women's work is undervalued by both men and women because it is not socially esteemed and it reflects badly on husbands, who are thought to be unable to support their families adequately (Kagitcibasi, 1981 b). For these reasons, women VOC respondents may have underreported the work they did. ${ }^{6}$

A higher proportion of women ( 9.5 percent) than of men (3.6 percent) were working as landless agricultural laborers; in contrast, more men than women were industrial workers (10 and 1 percent, respectively). More men than women were also entrepreneurs, salaried skilled workers, and government employees, though the proportions in those categories were small for both sexes. In contrast, small entrepreneurs and farmers constituted a large occupational category, for both sexes.

These findings reflect low participation of Turkish women in urban industrial jobs. A high proportion of the rural VOC women participated in agricultural labor, however. (Thirty percent were farmers and 45 percent were agricultural laborers.) With urbanization, women's overall labor force participation tends to decrease (Boserup, 1970; Kazgan, 1982). Some professions demanding high levels of education, however, such as university teaching, were more similarly distributed among men and women, though participation rates were very low for both sexes ( 2 percent of men, 0.7 percent of women). Percentages of women and men by occupational ćategory are presented in Table 4.

\section{Income}

Respondents reported generally low family incomes, the mean being around 3,000 Turkish lira (TL) per month (US\$120). Even if the shift in exchange rates (from $25 \mathrm{TL}$ to a dollar in 1975 to $50 \mathrm{TL}$ to a dollar in 1977) is taken into consideration, this figure is lower than the per capita income of $\$ 940$ established for 1977 (Prime Ministry State

6 Other researchers (Kandiyoti, 1977; Senyapili, 1979) have reported similar low percentages of female workers in both rural and semi-urban gecekondu areas of Turkey. Gecekondus are shanty towns around cities, established by migrants from rural areas. 
TABLE 4 Occupations of respondents, by sex (Percentage distribution)

\begin{tabular}{lcr}
\hline Occupation & Women & Men \\
\hline Professional & 0.7 & 1.7 \\
Entrepreneur & 0.1 & 3.6 \\
Official, manager & 0.4 & 1.4 \\
Technician, operator & 0.6 & 1.6 \\
Civil servant, middle-ranking employer & 4.7 & 10.7 \\
Small entrepreneur, farmer - & 34.7 & 47.1 \\
Skilled laborer & 2.3 & 9.2 \\
Semi-skilled laborer & 0.9 & 5.6 \\
Unskilled laborer & 13.5 & 17.5 \\
Family worker & 34.7 & 0.0 \\
Unclassified (Pensioner, part-time worker & & 1.5 \\
at home, in military) & 7.2 & 99.9 \\
\multicolumn{1}{c}{ All occupations } & 99.8 & \\
\hline
\end{tabular}

NOTE: Percentages do not sum to 100 because of rounding.

Institute of Statistics, 1979). ${ }^{7}$ It probably reflects only actual cash income and not other income in kind, however. It should be noted, too, that the purchasing power of the lira was much higher in 1975 than it is now, owing to a high rate of inflation.

\section{Family type and mobility}

Following Timur's (1972) conceptualization of family structure in Turkey, we delineated three main family types-nuclear, patriarchally extended, and transient extended. The main difference between patriarchally extended and transient extended family types is in whether the household head is the married son (transient extended family) or his father (patriarchally extended family). A transient extended family is on its way to becoming a nuclear family. Patriarchally extended families comprised 12.9 percent, transient extended 8.5 percant, and nuclear families 78.6 percent of the VOC families. These percentages are quite close to those obtained in another national survey conducted in 1968 (Timur, 1972).

Most of the nuclear families, however, were different in their life

7 These figures are based on 1975-77 exchange rates and do not apply to the present. 
styles from the isolated conjugal family units in Western industrial societies. Even though structurally nuclear, Turkish families, especially in the rural areas, tend to function as extended families with close-knit ties with their families of origin, kin, and neighbors (Olson, 1981; Duben, 1982; Kagitcibasi, 1981 b).

Over half of the respondents (57.3 percent) reported no rural-tourban or linear mobility. ${ }^{8}$ About a third ( 37 percent) of all respondents, or 86 percent of the rural sample, were rural peasants who had never lived for any extended length of time in urban areas. Another 37 percent were urban dwellers without any rural living experience. Of the 26 percent who had lived in both urban and rural areas, most were gecekondu dwellers who had recently migrated into cities and metropolitan centers from rural areas.

\section{Actual, desired, and ideal numbers of children}

The number of living children reported by respondents ranged from 0 to 13 , the mean being 2.9. Two-thirds ( 69 percent) of the respondents had 1 to 4 children. Only 18 percent had more, and only 13 percent had none. Nearly half (43 percent) of the female respondents reported having had at least one child who died after birth and 36 percent had experienced pregnancies that did not result in live births. Differences between rural and urban women in number of children borne were marked (rural mean: 3.16; urban mean: 2.58).

We defined respondents' desired number of children as the sum of children al ready born and still living (parity) and number of additional children wanted, including pregnancies. Desired number of children was elicited through several questions and probes. Respondents who wanted no additional children were asked if the number of children they already had was fine or would they have preferred to have fewer. In the latter case, the desired number of children would be less than parity. One-fifth ( 19 percent of women and 20 percent of men) were willing to say that they would have preferred to have fewer children than they already had.

We also wanted to know how many children respondents considered to be ideal. Ideal number of children we defined not as an abstract ideal, but rather as the number respondents would have liked to have

8 Linear mobility is movement between regions within the same population stratum (e.g., from one rural village to another rural village or from one small town to another). 
if they were to start all over again. When asking this question, interviewers added, if necessary: "Of course it would depend on many things, but if it were only up to you?" Most respondents had no trouble answering these questions.

Table 5 reveals that, on the average, both women and men desired and idealized only slightly more children than they actually had. For the whole sample the mean number of living children was 2.9. A substantial majority of respondents of both sexes desired and idealized two or three children. A two-child ideal was well established, especially among women. This finding is consistent with family-size ideals reported by respondents in contraceptive knowledge, attitude, and practice (KAP) surveys done in Turkey in the 1960s (Ozbay and Shorter, 1970; Shorter, 1968; Berelson, 1964). Mean numbers of children desired and idealized by our sample (3.2 and 2.7 , respectively, for the weighted total) were quite low compared with those in most other VOC countries. Desired number of children was lower only in West Germany and the United States, and ideal number was lower only in West Germany and South Korea.

Even though Turkey is a high-fertility country, with a crude birth

TABLE 5 Actual, desired, and ideal numbers of children

(Percentages of respondents stating specified numbers)

\begin{tabular}{|c|c|c|c|c|c|c|c|}
\hline \multirow[b]{2}{*}{$\begin{array}{l}\text { Number of } \\
\text { children }\end{array}$} & \multirow[b]{2}{*}{ Actual } & \multicolumn{3}{|l|}{ Desired } & \multicolumn{3}{|l|}{ Ideal } \\
\hline & & Women & Men & $\begin{array}{l}\text { Weighted } \\
\text { total }^{\mathrm{a}}\end{array}$ & Women & Men & $\begin{array}{l}\text { Weighted } \\
\text { total }^{\mathrm{a}}\end{array}$ \\
\hline 0 & 13 & 0.2 & 0.3 & 0 & 0.5 & 0.5 & 1 \\
\hline 1 & 16 & 4.5 & 5.4 & 5 & 7.8 & 7.8 & 8 \\
\hline 2 & 21 & 38.4 & 31.7 & 35 & 50.6 & 38.1 & 44 \\
\hline 3 & 18 & 28.3 & 30.8 & 30 & 24.9 & 32.6 & 29 \\
\hline 4 & 14 & 13.9 & 14.1 & 14 & 10.9 & 11.6 & 11 \\
\hline 5 & 8 & 6.1 & 8.6 & 7 & 2.6 & 5.7 & 4 \\
\hline $6+$ & 10 & 8.4 & 9.2 & 9 & 2.8 & 3.6 & 3 \\
\hline $\begin{array}{l}\text { All num- } \\
\text { bersb }\end{array}$ & 100 & 99.8 & 99.8 & 100 & 100.1 & 99.9 & 100 \\
\hline Mean & 2.9 & 3.1 & 3.3 & 3.2 & 2.6 & 2.9 & 2.7 \\
\hline
\end{tabular}

a In this and subsequent tables, weighted total refers to the weight (percentage) of that category in the total group, different weights being used for women and men. In this table and the following ones weighted population figures are used.

b Percentages may not sum to 100 because of rounding. 
rate of 39 per thousand in 1976 (Population Reference Bureau, 1976), the above figures indicate family-size norms and values closer to those in countries with moderate fertility levels (Bulatao, 1979b; Mauldin and Berelson, 1978).

\section{Basic values and sex roles}

Even though most of the questions in the VOC study concerned attitudes and behavior specifically related to children, some more general value questions were also asked of respondents. Responses to these provide insights into the social norms and values of the society.

\section{Life Values}

Findings of the first phase of the VOC Study indicate the existence of nine generally held values or satisfactions. Respondents in the second phase were asked to indicate how important each satisfaction was for them. They were then asked to identify the most and second most important values among the ones they had found important. Table 6 gives the values chosen as the most or second most important. The most striking difference between the sexes is in "being close to spouse," which was of great importance to the largest proportion (62.5 percent) of women, whereas it had major importance to only a fifth of the men. Although having a happy home was the most important value

TABLE 6 First and second most important life values

(Percentages of respondents ranking specified values first or second in importance)

\begin{tabular}{llll}
\hline Value & Women & Men & $\begin{array}{l}\text { Weighted } \\
\text { total }\end{array}$ \\
\hline To have a happy home & 57.3 & 43.1 & 51 \\
To be close to spouse & 62.5 & 19.2 & 40 \\
Financial security & 28.7 & 32.5 & 30 \\
To carry on family name & 15.7 & 28.8 & 23 \\
To be remembered after death & 15.7 & 22.0 & 19 \\
To achieve something, to succeed & 5.7 & 18.0 & 12 \\
To be accepted by others & 6.3 & 21.8 & 14 \\
Not to be alone, to have friends & 4.9 & 9.5 & 7 \\
To have fun and entertainment & 3.4 & 4.9 & 5 \\
\hline
\end{tabular}

NOTE: In this and subsequent tables more than one response was coded for each respondent; thus, percentages sum to more than 100 . 
for men and the second most important value for women, more women ( 57 percent) than men ( 43 percent) ranked it first or second in importance. These findings point to the home-bound role of women and their dependent status vis-à-vis their husbands. Men tended to accord more importance than women to values implying social recognition, such as achievement or success, being accepted by others, and, more traditionally, continuation of the family name and being remembered after death. The latter two values have implications for fertility because of their association with preference for sons. Finally, financial security ranked high in importance for both sexes, especially for the men. This finding was not surprising, for men are considered responsible for the financial well-being of the family. Thus, through respondents' first and second choices of general life values, different patterns emerged for women and men. These subjective values appeared to reflect the generally different life styles, outlooks, and roles of the two sexes.

\section{Internal Versus External Control}

Another significant sex difference emerged in the belief in internal versus external control of reinforcement. Belief in internal control of reinforcement, according to Rotter (1966), means a tendency to assume full responsibility for one's actions and lot in life. In contrast, belief in external control is the tendency to attribute responsibility for one's situation to an outside agent, such as God, fate, or other people. Thus, belief in internal control implies a tendency toward autonomous, self-reliant, active behavior, whereas belief in external control implies a passive, fatalistic outlook.

As is apparent from Table 7, on the first three items measuring belief in external control, women consistently scored higher than men; the difference was significant at .001 level for all three items. On the fourth item, which measured belief in intemal control, men scored higher than women. The overall mean for perceived individual efficacy was, accordingly, 11.9 for men and 9.6 for women (over a range of 4 to 20). The implications of this finding for differential individual modernity, world views, and roles of men and women are obvious. It is consistent with the finding from an earlier study (Kagitcibasi, 1973) of greater belief in external control among girls than among boys in Turkish high schools. In that case the difference in perceived individual efficacy was probably due to the differential socialization of girls and 
TABLE 7 Perceived individual efficacy

(Percentages of respondents, by reaction to specified statements)

\begin{tabular}{|c|c|c|c|c|c|c|}
\hline \multirow[b]{2}{*}{ Statement } & \multicolumn{3}{|c|}{ Women } & \multicolumn{3}{|l|}{ Men } \\
\hline & Disagr & Neutral & Agree & Disag & Neutral & Agree \\
\hline $\begin{array}{l}\text { Getting what you want is a } \\
\text { matter of luck }\end{array}$ & 15.1 & 3.2 & 81.6 & 37.0 & 2.3 & 60.7 \\
\hline $\begin{array}{l}\text { It is not al ways wise to plan } \\
\text { far ahead because many } \\
\text { things turn out to be a matt } \\
\text { of good or bad for tune } \\
\text { anyway }\end{array}$ & 10.7 & 1.8 & 87.5 & 28.1 & 1.5 & 70.4 \\
\hline $\begin{array}{l}\text { Many times you feel that yo } \\
\text { have little influence over the } \\
\text { things that happen to you }\end{array}$ & 12.7 & 6.0 & 81.4 & 27.5 & 5.5 & 67.0 \\
\hline $\begin{array}{l}\text { When you make plans, you } \\
\text { are almost certain you can } \\
\text { make them work }\end{array}$ & 8.0 & 7.8 & 84.2 & 4.8 & 3.0 & 92.2 \\
\hline
\end{tabular}

boys in Turkish society, where more autonomy, self-reliance, and freedom are expected of boys than of girls. In the VOC survey the difference could be due, at least in part, to an acquiescent response bias on the part of women. This tendency to agree (Couch and Keniston, 1960; Peabody, 1966; Kagitcibasi, 1970) reflects submissive, accepting tendencies or admission of ignorance in conformity with social expectations from women (Sistrunk and McDavid, 1971).

It can also be argued that both sexes demonstrated an acquiescent response bias, for the majority of men as well as women agreed with all four items, even though doing so was to be inconsistent. Indeed, there appears to be a confounding response bias here. It should be noted, however, that although more women than men agreed with the first three items indicating belief in external control, fewer women than men agreed with the fourth item indicating belief in internal control. Thus, the results cannot be attributed solely to a response bias.

\section{Family Dynamics}

The survey included questions about family dynamics and decision processes. Answers to questions about responsibility for decisionmaking within the family revealed consistent sex differences in the frequency of responses reporting male decision-making, relatively 
more men than women attributing decisions to the man. More importantly, however, the frequency of responses attributing decisionmaking to the man was consistently higher than that of responses attributing it to the woman or to both spouses, among female as well as male respondents. This finding, which was expected and consistent with results from earlier studies (e.g., Kagitcibasi, 1973, 1975a; Kandiyoti, 1974), provides additional evidence of sex-based status differences in the Turkish family.

Differentiated sex roles are also apparent from Table 8. It is noteworthy that on such a basic topic as desired number of children, a substantial proportion of respondents reported no communication with spouse.

These findings describe the family context in relation to which other findings of the study need to be interpreted. Compared with the other VOC samples, Turkish respondents reported the greatest degree of male decision-making. ${ }^{9}$ In all the VOC countries except Turkey, responses to all three questions about family decisions revealed that shared decision-making was more prevalent than male decision-making. Turkish respondents also reported the least role sharing and communication of all the VOC samples.

These findings, together with those relating to basic values and women's low level of education, point to traditional sex-role segregation within families and low status of women in Turkey. They are consistent with previous research findings and observations (e.g., Kagitcibasi, 1973, 1975a, 1979; Kandiyoti, 1977; Abadan-Unat, 1976; Kiray, 1976; Fallers and Fallers, 1976; Meeker, 1976; Magnarella, 1974). To some extent these findings reflect traditional Middle East culture, but they should not be attributed mainly to the Moslem religion. In Indonesia, the other Moslem VOC country, sex-role sharing was found to be much more prevalent than in Turkey.

\section{Women's Occupations and Status}

The Turkish VOC findings show that the type of work a woman does, rather than whether she holds a job or not, is indicative of her status. As mentioned before, whether a woman is working or not is subject to interpretation, especially in the agricultural sector. Working as a family worker on family land has no bearing on a woman's status within the

9 Detailed comparisons on this topic are made in another context (Kagitcibasi, 1979). 
TABLE 8 Family decision-making, communication, and role sharing (Percentages of respondents giving specified responses)

\begin{tabular}{|c|c|c|c|}
\hline Question and response & Women & Men & Total \\
\hline \multicolumn{4}{|l|}{ DECISION-MAKING } \\
\hline $\begin{array}{l}\text { Who decides about buying something new? } \\
\text { Woman decides } \\
\text { Man decides } \\
\text { Both decide }\end{array}$ & $\begin{array}{r}9.5 \\
73.1 \\
17.3\end{array}$ & $\begin{array}{r}3.2 \\
83.4 \\
13.5\end{array}$ & $\begin{array}{r}6 \\
78 \\
15\end{array}$ \\
\hline $\begin{array}{l}\text { Who decides about how many children to have } \\
\text { Woman decides } \\
\text { Man decides } \\
\text { Both decide }\end{array}$ & $\begin{array}{l}16.0 \\
50.7 \\
33.2\end{array}$ & $\begin{array}{r}5.8 \\
62.2 \\
32.1\end{array}$ & $\begin{array}{l}11 \\
56 \\
33\end{array}$ \\
\hline $\begin{array}{l}\text { Who decides about using birth control? } \\
\text { Woman decides } \\
\text { Man decides } \\
\text { Both decide }\end{array}$ & $\begin{array}{l}28.2 \\
36.1 \\
35.7\end{array}$ & $\begin{array}{l}17.2 \\
38.6 \\
44.2\end{array}$ & $\begin{array}{l}23 \\
37 \\
39\end{array}$ \\
\hline \multicolumn{4}{|l|}{ COMMUNICATION } \\
\hline $\begin{array}{l}\text { Have you talked with your spouse about how } \\
\text { many children he/she wants? } \\
\text { Yes } \\
\text { No }\end{array}$ & $\begin{array}{l}63.8 \\
36.2\end{array}$ & $\begin{array}{l}56.0 \\
44.0\end{array}$ & $\begin{array}{l}60 \\
40\end{array}$ \\
\hline \multicolumn{4}{|l|}{ ROLE SHARING } \\
\hline $\begin{array}{l}\text { Do you do things together with your spouse } \\
\text { outside the house? } \\
\text { Yes } \\
\text { No }\end{array}$ & $\begin{array}{l}61.8 \\
38.2\end{array}$ & $\begin{array}{l}61.8 \\
38.2\end{array}$ & $\begin{array}{l}62 \\
38\end{array}$ \\
\hline $\begin{array}{l}\text { Does your spouse help with the housework? } \\
\text { Yes } \\
\text { No }\end{array}$ & $\begin{array}{l}54.7 \\
45.3\end{array}$ & $\begin{array}{l}77.5 \\
22.5\end{array}$ & $\begin{array}{l}66 \\
34\end{array}$ \\
\hline $\begin{array}{l}\text { How often does your spouse help? } \\
\text { Never } \\
\text { Rarely } \\
\text { Sometimes } \\
\text { Regularly }\end{array}$ & $\begin{array}{l}45.3 \\
12.5 \\
32.1 \\
10.1\end{array}$ & $\begin{array}{r}22.5 \\
17.3 \\
53.0 \\
7.3\end{array}$ & $\begin{array}{r}34 \\
15 \\
43 \\
9\end{array}$ \\
\hline
\end{tabular}

a For men question was worded "Do you help with the housework?"

b For men question was worded "How often do you help?"

family. Our findings indicate that working or not working in itself is not significantly related to the woman's status; the type and prestige of her occupation, however, is.

The occupations mentioned by respondents were coded and rankordered according to the social prestige generally accorded to them. 
Rural-urban and modernism dimensions were implicit in the rankordering, which was based on previous research on modernization in Turkey (Kagitcibasi, 1973, 1981b) and ranged from agricul tural laborer to professional/managerial occupations (Table 9). According to the coding scheme, the categories of skilled worker (blue-collar), civil servant/technical (white-collar), and professional/managerial occupations represent progressive "professionalism." In the Turkish context this concept has the meaning of an occupational involvement requiring substantial education (education + occupation).

We found a significant relationship between women's occupational prestige and their status within the family (Table 9). The more professional women were, the lower was the degree of male decision-making within the family and the higher were the degree of role sharing and the level of communication between spouses. Accordingly, woman's total status, an index made up of the three status variables, was also positively related to occupational level. Women in urban, and especially professional, occupations had notably higher status within the family than women working in agricultural (rural) and unskilled jobs.

Rank-order correlations between women's occupational level and status variables indicated that as the prestige level of women's occupation increased, male decision-making decreased, whereas role sharing between spouses and women's overall status in the family increased (rho: $-.24, p<.001$, for male decision-making; .08, $p<.004$, for role sharing between spouses; and .13, $p<.001$, for women's total status within the family). Women's belief in internal control of reinforcement was also found to be positively associated with professionalism (rho: .13, $p<.001$ ).

The general level of development of the area where a woman lived, as determined by rural-urban designation and population size, had a positive relationship to her occupational level $(r=.41)$. (For level of development we used an index combining these two criteria, with least developed rural areas and most developed urban and metropolitan areas constituting the extremes.) These correlations suggest that, with development of an area, women's occupational status and family status rise, forming a meaningful pattern of social change in sex roles.

The characteristics of respondents described above provide us with a general understanding of the population under study. Current age and age at marriage, education, occupation, income, family type and mobility, parity, desired and ideal number of children, basic values, 
TABLE 9 Women's status within the family, by occupation (Percentages of women)

\begin{tabular}{|c|c|c|c|c|c|c|}
\hline \multirow[b]{2}{*}{ Status variable } & \multicolumn{6}{|l|}{ Occupation } \\
\hline & $\begin{array}{l}\text { Professional/ } \\
\text { managerial }\end{array}$ & $\begin{array}{l}\text { Civil servant/ } \\
\text { technical }\end{array}$ & $\begin{array}{l}\text { Skilled } \\
\text { laborer }\end{array}$ & $\begin{array}{l}\text { Unskilled } \\
\text { laborer }\end{array}$ & Farmer & $\begin{array}{l}\text { Agricultural } \\
\text { laborer }\end{array}$ \\
\hline \multicolumn{7}{|c|}{ Degree of decision-making by man } \\
\hline Low & 5.5 & 24.3 & 5.8 & 4.4 & 3.7 & 1.7 \\
\hline Medium & 78.8 & 57.8 & 39.7 & 41.3 & 14.3 & 33.1 \\
\hline High & 15.7 & 17.9 & 54.5 & 54.3 & 82.0 & 65.2 \\
\hline \multicolumn{7}{|c|}{$\chi^{2}=97.7, p<.001, N=955$} \\
\hline \multicolumn{7}{|c|}{ Degree of role sharing } \\
\hline Very low & 0.0 & 6.2 & 20.8 & 20.8 & 20.0 & 19.3 \\
\hline Low & 22.3 & 27.3 & 32.2 & 28.1 & 23.8 & 33.0 \\
\hline Medium & 17.9 & 34.8 & 14.1 & 20.8 & 20.8 & 17.6 \\
\hline High & 59.7 & 34.8 & 14.1 & 20.8 & 20.8 & 17.6 \\
\hline \multicolumn{7}{|c|}{$\chi^{2}=39.6, p<.002, N=1,004$} \\
\hline \multicolumn{7}{|c|}{ Level of communication } \\
\hline Low & 21.5 & 15.3 & 44.5 & 30.5 & 52.9 & 33.3 \\
\hline High & 78.5 & 84.7 & 55.5 & 69.5 & 47.1 & 66.7 \\
\hline \multicolumn{7}{|c|}{$\chi^{2}=46.6, p<.001, N=1,037$} \\
\hline \multicolumn{7}{|c|}{ Women's total status } \\
\hline Low & 5.5 & 13.6 & 16.4 & 21.5 & 18.7 & 16.0 \\
\hline Medium & 41.2 & 43.9 & 67.7 & 60.9 & 77.2 & 79.6 \\
\hline High & 53.3 & 42.5 & 15.9 & 17.6 & 4.1 & 4.5 \\
\hline$\chi^{2}=191.2, p<.0$ & & & & & & \\
\hline
\end{tabular}

NOTE: Numbers of respondents are large because farmers and agricultural laborers are included who may not have been earning cash income. 
and sex roles have been presented as important respondent characteristics. The values ascribed to children by respondents and other findings of the Turkish VOC Study, discussed in the next section, should be interpreted within the context of those characteristics.

\section{MAJOR FINDINGS}

Owing to the length of the survey questionnaire and the diversity of topics covered, a great deal of information was obtained from respondents. ${ }^{10}$ Here major findings are presented as they bear on the working hypotheses of the study. Relating the findings to the study's hypotheses should provide a logical order to the discussion as well as tie the results to the theoretical model presented in Figure 1.

\section{Hypotheses}

The hypotheses of the Turkish VOC Study derive in part from the theoretical model, discussed at the outset of this paper, and also from the results of the first phase of the VOC Study and of the Turkish pilot study. They were designed to test the validity of the model and to provide conceptual guidelines for analyzing the findings. The hypotheses refer to the proposed relationships among the independent (an tecedent), intervening, and dependent (consequent) variables constituting our model. To test the hypotheses we have used multiple regression analysis to explain the variance in the dependent variables, controlling extraneous variables as much as possible and allowing causal interpretations. When such analysis could not be undertaken, we used correlations and measures of association to clarify relationships among variables, and at times searched for "logical" causality.

The first two hypotheses are general statements of our multidimensional conceptualization of the values of children, as opposed to a more simplistic view of children's value. The remaining hypotheses define more or less specific relationships that we posited to exist among variables. They assume values of children to be variables that intervene between antecedent background and consequent fertility variables. The hypotheses are as follows:

1. Values attributed to children are varied and are of three types: psychological, economic or utilitarian, and social or normative.

10 A more comprehensive presentation of the findings (in Turkish) is found in Kagitcibasi (1981b); other descriptions of findings are in Kagitcibasi (1981a, 1982a, 1982b). 
2. Costs attributed to children are varied and are of three types: psychological, economic, and social.

3. With socioeconomic development, the types of value attributed to children change. Specifically, as level of development and individual socioeconomic status increase (as indicated by increased education, income, occupation level, development level of area of residence, urbanism, and rural-to-urban mobility), the economic/utilitarian value of children loses importance, and their psychological value gains importance. ${ }^{11}$

4. With socioeconomic development of an area and increased socioeconomic status of couples, the opportunity cost of children increases.

5. As a couple's parity increases, the economic/utilitarian value of their children increases and the psychological value decreases.

6. As parity increases, the economic cost of children increases and the opportunity cost decreases.

7. Values attributed to sons are different from those attributed to daughters, the economic value of the sons assuming importance.

8. As communication between spouses, role sharing, and decision sharing increase (i.e., as a woman's status within the family increases), the economic/utilitarian value of children and boy preference decrease and the psychological value of children increases.

9. Values of children explain some of the variance in couples' fertility even when socioeconomic development variables are controlled. Specifically, the economic/utilitarian value of children is a predictor of high fertility and the psychological value is a predictor of low fertility. Boy preference is also a predictor of high fertility.

10. As communication between spouses, role sharing, and decision sharing increase, fertility decreases.

11 Throughout this paper "development" refers to both the level of urbanization and economic development of the area of residence and to the socioeconomic status of the individual and the family. The term has this dual meaning because the two aspects of development are so closely associated that they often imply each other or may be used as indicators of each other in Turkish society. The type of analysis is different for each level of development, however, and therefore the sense in which "development" is used is made clear whenever the term is used. 
11. As level of development and socioeconomic status increase, fertility decreases.

As will be apparent throughout the analysis and discussion, we assumed that the different development levels of residential areas, and also the different socioeconomic levels of respondents, reflected varying levels of modernization. Thus, the cross-sectional or synchronic variations revealed by the VOC data might be considered to approximate longitudinal or diachronic variations, though an equivalence between the two is not meant.

\section{Values of children}

The values attributed to children by parents reflect both the needs of the parents and the place of children in the family and society. Those values are the focus of this study and generally constitute the basis of the social-psychological orientation to fertility research. As stated earlier, the value of children as a concept has also enjoyed importance in the economic literature.

According to microeconomic theory, the value of children for the parent is a unidimensional economic value, whereas in the socialpsychological orientation, as exemplified by the VOC Study, it is considered to be a multidimensional, complex value. Thus, whereas microeconomic theory posits a total change in the unidimensional value of children with a change in income and other indicators of social change, the social-psychological orientation suggests that several predictions can be made about changes in the different dimensions of children's value as social change occurs. Our hy potheses are examples of such predictions. The first hypothesis, in fact, asserts the multidimensionality of the value of children, in contrast to a unidimensional conceptualization.

We measured respondents' perceptions of the value of children by means of various questions, most of them structured. At the beginning of the interview, however, respondents were asked two open-ended questions about the advantages and disadvantages of having children, the purpose of which was to ascertain, from respondents' spontaneous answers, which values and costs of children were salient for them. The great variety of responses to the questions suggests that children have many values, positive and negative, for couples. These values are grouped in to the categories shown in Figure 1.

As is apparent from Table 10, respondents were able to verbalize an 
TABLE 10 Advantages of having children

(Percentages of respondents mentioning specific advantages and major code categories)

\begin{tabular}{|c|c|c|c|}
\hline Advantage & Women & Men & $\begin{array}{l}\text { Weighted } \\
\text { total }\end{array}$ \\
\hline HELP FROM CHILDREN & 56.0 & 54.8 & 55 \\
\hline $\begin{array}{l}\text { Help in housework } \\
\text { Help in old age } \\
\text { Financial and practical help }\end{array}$ & $\begin{array}{l}11.4 \\
38.3 \\
20.4\end{array}$ & $\begin{array}{r}7.7 \\
35.9 \\
20.6\end{array}$ & $\begin{array}{l}10 \\
37 \\
21\end{array}$ \\
\hline BENEFIT FOR FAMILY, GOD, AND COUNTRY & 13.9 & 321 & 23 \\
\hline $\begin{array}{l}\text { Family name, family line } \\
\text { Religious and social obligations }\end{array}$ & $\begin{array}{l}8.1 \\
6.4\end{array}$ & $\begin{array}{l}13.9 \\
21.8\end{array}$ & $\begin{array}{l}11 \\
14\end{array}$ \\
\hline BENEFIT FOR THE MARRIAGE & 14.0 & 10.9 & 12 \\
\hline Marital bond, home life & 14.0 & 10.9 & 12 \\
\hline SOCIAL ACCEPTANCE & 13.0 & 15.5 & 14 \\
\hline Adult status, social norms & 13.0 & 15.5 & 14 \\
\hline CHILDREN AS COMPANIONS, FUN & 37.9 & 35.1 & 36 \\
\hline $\begin{array}{l}\text { Companionship, love, avoidance of loneliness } \\
\text { Happiness, fun at home, amusement }\end{array}$ & $\begin{array}{l}21.6 \\
20.8\end{array}$ & $\begin{array}{l}11.4 \\
26.1\end{array}$ & $\begin{array}{l}16 \\
23\end{array}$ \\
\hline LIVING THROUGH CHILDREN & 21 & 3.1 & 3 \\
\hline Living through children & 2.1 & 3.1 & 3 \\
\hline CHILDREN AS ACCOMPLISHMENT & 9.5 & 8.0 & 9 \\
\hline Achievement, power & 9.5 & 8.0 & 9 \\
\hline CHARACTER, FULFILLMENT, EXPERIENCE & 4.9 & 7.6 & 6 \\
\hline $\begin{array}{l}\text { Incentive to succeed } \\
\text { Fulfillment }\end{array}$ & $\begin{array}{l}0.8 \\
4.2\end{array}$ & $\begin{array}{l}2.9 \\
4.8\end{array}$ & $\begin{array}{l}2 \\
5\end{array}$ \\
\hline MISCELLANEOUS & 19.9 & 21.6 & 21 \\
\hline
\end{tabular}

impressive variety of advantages of children. This is evidence, in itself, that children provide complex satisfactions and suggests that they are not replaceable by any single alternative source of those satisfactions.

On one hand, respondents said they valued children for their material contributions to the family both when they are young and especially in parents' old age-that is, for their economic or utilitarian value. On the other hand, they also stressed children's psychological value, in strengthening the marital bond and providing companionship, love, joy, and liveliness. The social or normative value of children was also mentioned, though not so frequently as their economic value. It emerged especially in responses about continuing the family name and contributing to society. On closer examination, the very high salience 
of the old-age security value of children, combined with their material contributions to the family at a young age, reflects a general utilitarian outlook. This utilitarian perception of children's value involves heavy demands and expectations of support from children in a context of interdependent, interpersonal ties.

Thus, the positive values that respondents spontaneously attributed to children are highly varied and have economic/utilitarian, psychological, and social/normative characteristics. This finding supports hypothesis 1 . Hypothesis 1 also finds support in responses to a structured question about reasons for wanting another child. All respondents, including those who did not want more children, were presented with a list of 12 reasons for wanting another child and asked first to rate each according to its importance and then to identify the most important and second most important reason. As is apparent from Table 11, the economic/utilitarian, psychological, and social/normative reasons considered most important for wanting another child were somewhat different from the advantages of children in general that respondents mentioned most frequently. Old-age security, however, ranked high in both types of response. As this value was emphasized as a reason for wanting more children, it appears to be associated with high fertility. This association is explored later.

An important difference between male and female respondents was in the importance attached to bringing the spouses closer together, as a reason for wanting another child. The much greater importance of this reason for women than for men suggests a dependent, lower status of the woman in the marital relationship. Because the husband has other social contacts, being close to the spouse is not so important for him as for the wife, who finds another child useful in "bringing the husband back home." The desire to draw the husband closer to home appears to be an important motivation for childbearing that does not receive much attention in fertility literature.

Another major sex difference was in the rankings assigned to wanting another child to continue the family name, which was even more important to men than bringing the spouse closer was to women. This traditional value, involving boy preference, was not nearly so important to women, even though wanting another child to have a (another) boy was equally important to both sexes. It appears that boy preference was about equally prevalent among men and women, but for basically different reasons. Whereas for men continuation of the family 
TABLE 11 Most important reasons for wanting another child (Percentages of respondents ranking specified reasons as most important)

\begin{tabular}{|c|c|c|c|c|}
\hline Reason & Wome & & Men & \\
\hline $\begin{array}{l}\text { To have someone for you to love and } \\
\text { care for }\end{array}$ & 4.9 & $(10.6)$ & 5.7 & $(13.1)$ \\
\hline $\begin{array}{l}\text { So that there will be one more person to } \\
\text { help your family economically }\end{array}$ & 12.9 & $(22.8)$ & 128 & $(25.7)$ \\
\hline Because you want to have (another/a) boy & 15.5 & $(22.8)$ & 12.1 & $(22.1)$ \\
\hline $\begin{array}{l}\text { To provide a companion for your (children/ } \\
\text { child) }\end{array}$ & 3.6 & $(8.6)$ & 3.2 & (6.5) \\
\hline $\begin{array}{l}\text { Because another child would give (your } \\
\text { husband/you) more reason to succeed in } \\
\text { (his/your) work }\end{array}$ & 1.2 & $(2.8)$ & 2.9 & (6.5) \\
\hline $\begin{array}{l}\text { To be sure that in your old age you will } \\
\text { have someone to help you }\end{array}$ & 22.0 & (39.8) & 14.3 & $(31.6)$ \\
\hline To have a child to help around the house & 2.4 & (11.9) & 1.8 & $(8.8)$ \\
\hline $\begin{array}{l}\text { Because of the pleasure you get out of } \\
\text { watching children grow }\end{array}$ & 4.0 & $(11.6)$ & 7.4 & $(15.9)$ \\
\hline $\begin{array}{l}\text { To bring your (husband/wife) and yourself } \\
\text { closer together }\end{array}$ & 17.7 & $(32.3)$ & 9.4 & $(18.5)$ \\
\hline Because you want to have (another/a) girl & 5.7 & $(10.5)$ & 3.6 & $(6.7)$ \\
\hline To help carry on your family name & 6.3 & $(14.4)$ & 22.2 & (31.3) \\
\hline $\begin{array}{l}\text { Because it is fun to have young children } \\
\text { around the house }\end{array}$ & 3.8 & $(12.0)$ & 4.6 & (13.2) \\
\hline
\end{tabular}

NOTE: Percentages in parentheses represent combined frequency of first and second most important reasons.

name was important, for women the status value of bearing a son was probably more salient. This would be the case especially in traditional areas, where anthropological research (e.g., Stirling, 1965; Kandiyoti, 1974; Meeker, 1976) has found that a woman's status is defined mainly by her age and (male) children. The old-age security value of a son, however, appears to have been similarly salient for men and women.

A related open-ended question inquired about respondents' reasons for not wanting fewer than the number of children they had expressed a desire for. Their answers (Table 12) again throw light on the variety of values attributed to children and on differences between men and women in holding those values. Among both women and men the 
TABLE 12 Reasons for not wanting fewer than the desired number of children

(Percentages of respondents mentioning specified reasons)

\begin{tabular}{lcr}
\hline Reason & Women & Men \\
\hline Help in housework & 0.4 & 1.1 \\
Caring for other children & 0.6 & 0.8 \\
Help in old age & 2.7 & 4.9 \\
Financial and practical help & 6.6 & 10.1 \\
Family name, family line & 1.2 & 4.5 \\
Religious and social obligations & 0.4 & 1.6 \\
Marriage, home life & 28.2 & 17.1 \\
Adult status, social norms & 5.9 & 3.6 \\
Number preference & 11.6 & 12.2 \\
Companionship, love & 10.0 & 7.8 \\
Happiness & 0.2 & 0.6 \\
Play, fun, distraction & 0.6 & 0.7 \\
Companion for child/children & 8.9 & 6.9 \\
Living through children & 0.0 & 0.6 \\
Achievement, power & 0.8 & 0.7 \\
Character, responsibility & 0.2 & 0.2 \\
Incentive to succeed & 0.1 & 0.1 \\
Less expense & 0.0 & 0.0 \\
Replacement in case of child loss & 15.5 & 13.8 \\
Miscellaneous & 28.5 & 34.4 \\
\hline
\end{tabular}

most frequently mentioned (or salient) reason was that children strengthened the marital bond, although about a third again as many women as men cited this reason. Fear of child mortality and the replacement value of children were also mentioned with substantial frequency by both sexes. More men than women mentioned financial and practical help that children provide to parents, and somewhat more women than men mentioned children's companionship and love.

Respondents' fear of child loss may be considered realistic in view of the high infant mortality rate in Turkey (119 per thousand). Among the VOC countries this rate is exceeded only by Indonesia's. Moreover, 42.6 percent of the VOC women in Turkey had had at least one child die after birth-the highest proportion among the VOC countries. Thus, both the values associated with children and the common mortality experience of respondents accounted for their not wanting fewer than a particular number of children. 
The multidimensional nature of values ascribed to children, proposed in our first hypothesis, thus finds some support in the data. To test this hypothesis further, the reasons ranked as important for wanting another child were subjected to factor analysis (Esmer, 1979). The results lend further support to the hypothesis, for three factors were clearly differentiated from one another: (1) an economic/utilitarian VOC factor, consisting of the reasons "to have one more person to help family economically," "to be sure to have someone to help you in old age," and "to have a child to help around the house"; (2) a psychological VOC factor, in which the reasons were "because of the pleasure you get out of watching children grow," "to bring your spouse and you closer together," and "because it is fun to have young children around the house"; and (3) a social/normative VOC factor, consisting of the reasons "to help carry on your family name" and "because you want to have a (another) boy." The third factor was labeled social/normative because continuation of the family name and boy preference are socially prescribed values that contribute to fertility in traditional Turkish society. They have great importance in the prevalent patrilineal family system, where sons are highly valued.

To summarize, our multidimensional conceptualization of the value of children found empirical support in spontaneous responses to openended questions about the advantages of having children and reasons for wanting a particular number of children, in the degree of importance at tached to suggested reasons for wanting another child, and in a factor analysis of those structured reasons. The spontaneous responses and ranking of structured responses provided descriptive evidence for hypothesis 1 . The factor analysis directly tested the hypothesis and provided direct empirical support to it. Even though it was based on responses to only one set of questions (reasons for wanting another child), the three value dimensions that emerged are clearly delineated. In some of our analyses, we used these factors as they were, scoring additively the level of importance attributed to the items. In others, we combined them with other items to form indices, which again were scored additively.

These findings point to the complexity of the values attributed to children by Turkish parents and suggest that a unidimensional conceptualization of their value-as, for example, being only economicis inappropriate. The multidimensional nature of children's value becomes especially important in relation to respondents' socioeconomic 
backgrounds and childbearing patterns. This is so because different types of relationship may be expected to exist among economic values of children, development level of an area, and fertility from those among psychological values of children, development level, and fertility.

\section{Costs of children}

We hypothesized costs of children, like values, to be of three typespsychological, economic, and social (Figure 1). Table 13 presents the frequency of spontaneous responses to an open-ended question, posed at the beginning of the interview, about the disadvantages of having children. The variety of disadvantages mentioned by Turkish respondents supports our hypothesis. Economic and psychological costs

TABLE 13 Disadvantages of having children

(Percentages of respondents mentioning specific disadvantages and major code categories)

\begin{tabular}{lrrr}
\hline Disadvantage & Women & Men & $\begin{array}{c}\text { Weighted } \\
\text { total }\end{array}$ \\
\hline ECONOMIC cosTS & 39.1 & 55.0 & 47 \\
Cost of education & 5.7 & 13.2 & 9 \\
General financial costs & 37.5 & 49.2 & 43 \\
EMOTIONAL/PHYSICAL COSTS & 50.9 & 19.3 & 35 \\
More work & 30.6 & 12.7 & 22 \\
Emotional strain, responsibility & 20.0 & 7.9 & 14 \\
Effects on heal th, appearance & 1.0 & 0.1 & 1 \\
Pregnancy, fear of abnormal birth & 5.5 & 0.8 & 3 \\
UPBRINGING PROBLEMS & 33.8 & 30.0 & 32 \\
Discipline & 19.4 & 19.7 & 20 \\
Sickness & 14.7 & 7.6 & 11 \\
Worry over child's future & 4.0 & 7.4 & 6 \\
RESTRICTION OF PARENTS' FREEDOM & 14.4 & 12.4 & 13 \\
Tied down & 9.8 & 8.1 & 9 \\
Can't work & 4.2 & 2.6 & 3 \\
Marital strains & 1.4 & 2.0 & 2 \\
SOCIAL PROBLEMS & 1.0 & 0.2 & 1 \\
Overpopulation & 1.0 & 0.2 & 1 \\
MISCELLANEOUS & 18.2 & 27.0 & 23 \\
\hline
\end{tabular}


emerged as being salient; but social costs were much less salient and less clearly differentiated than economic and psychological ones, providing only partial support for hypothesis 2 .

The most frequently mentioned disadvantages of having children were emotional/physical and economic costs, which were closely followed by problems of upbringing. As expected, economic costs were more salient for men and psychological costs more salient for women, who carry the main load of childcare in the Turkish family. One interesting finding was the frequency with which being "tied down" by children was mentioned. Even though women have less discretionary use of their time than men in Turkish society, this disadvantage was slightly more salient for them. Women, while accepting their traditional role as caretakers of children, still see this aspect of parenthood as a disadvantage.

Respondents were asked what caused the most worry or emotional strain in raising children. Their answers indicated that children's health problems were especially salient for women ( 89 percent of whom spontaneously mentioned such problems) and disciplinary problems were particularly salient for men ( 97 percent spontaneously mentioning them). This pattern of response is in line with the differentiation between the father's traditional disciplinary role and the mother's childcare role.

Thus, the responses to these unstructured questions indicate that negative values of children are also varied and multidimensional. Respondents clearly identified economic and psychological disvalues of children. These findings lend support to a complex conceptualization of the value of children.

A structured question, in which all respondents, regardless of whether they wanted more children or not, were asked to rank in importance ten reasons for not wanting another child, also assessed perceived costs of children. For both women and men, by far the most important reason was the financial cost of children (Table 14). Of second importance was the concern that respondents could not give enough care and attention to all their children, which apparently implies that an additional child would entail both psychological and economic costs. Also considered important were the difficulty of 
TABLE 14 Most important reasons for not wanting another child (Percentages of respondents ranking specified reasons as most important

Reason Women Men

Because having another child would be a

financial burden for your family

$30.2 \quad(43.7) \quad 24.2$

Because you couldn't spend as much time with your spouse

$\begin{array}{lll}4.8 & (9.3) \quad 2.9\end{array}$

Because you would not be as free to do what you want to do

$5.6 \quad(13.7) \quad 6.0 \quad(11.3)$

Because you are concerned about the problem of overpopulation

$3.9 \quad(8.1) \quad 14.3 \quad(22.6)$

Because it would be harder for (you/your wife) to have a job

$7.7 \quad(16.4) \quad 6.5$

Because of the worries children cause when they are sick

$11.5 \quad(24.2) \quad 8.3$

Because another child would be a lot of work and bother for you

$9.1 \quad(26.4) \quad 6.9$

Because your spouse and you are too old for another child

$4.8 \quad(7.9) \quad 5.0$

Because you would not be able to give enough care and attention to all your children

$11.0 \quad(28.3) \quad 13.8$

Because children would be hard to discipline and control

$11.3 \quad(21.9)$

12.1

NOTE: Percentages in paren theses represent combined frequency of first and second most important reasons.

disciplining and controlling the children (ranked important by slightly more men than women) and the "work and bother" that another child would be (important to somewhat more women than men). These differences in rankings by women and men reflect the traditional sex-role differentiation in childrearing, which accords to the father authority for decision-making and control, and to the mother major childcare responsibility.

A related open-ended question asked respondents to cite reasons for not wanting more than the number of children they had expressed a desire for. Here again, financial costs were by far the most salient to both men and women, all of whom mentioned that reason. Other costs were also cited but were much less salient, 34 and 35 percent, 
respectively, of men mentioning opportunity costs and concern for the child's future, and 29 percent of women citing the added work of more children. These findings indicate the great salience of economic costs of children, together with an awareness of other types of costs, in line with our conceptualization.

\section{Socioeconomic development and values of children}

Our third hypothesis was that with development, the economic value of children decreases and their psychological value increases. This is one of the basic propositions of the VOC Study, based on a multidimensional conceptualization of children's value to parents. In other words, we assumed different values attributed to children to be differentially affected with development, and also to affect fertility differentially. This section deals with the first part of the proposed sequence of causal relationships, which received confirmation from many of the study's findings.

As explained in the methodology section, the sample locations were stratified into four broad levels of socioeconomic development. In addition to development level of the sample province, population size of the sample location determined the scale of development underlying the VOC sample stratification. In this scale the lowest level of development characterized rural villages of 2,000 or fewer inhabitants in the least developed provinces, and the highest development level characterized the three metropolitan areas.

For purposes of analysis we scored development level in two ways. In simple cross-tabulations (Tables 15 and 19) we used only the four levels of development (least developed, medium, developed, and metropolitan). In later cross-tabulations, correlations, and multiple regressions (Tables 21, 22, 30, 33, and 34) we used an index based on both development status and population size, which yielded ten levels.

Table 15 shows development level to be inversely related to the old-age security value of children ${ }^{12}$ and positively related to the companionship value of children, the latter being a psychological value. Another psychological value, the sense of accomplishment derived from having children, was also positively related to development,

12 Several responses to the open-ended question about the advantages of children were coded as old-age security. Some respondents specifically mentioned financial assistance to parents in old age. Others were more general, referring to security in old age or the loyalty of sons. 
TABLE 15 Advantages of having children, by development stratum

(Percentages of respondents mentioning specific advantages)

\begin{tabular}{|c|c|c|c|c|c|c|c|c|}
\hline \multirow[b]{2}{*}{ Advantage } & \multicolumn{2}{|c|}{ Least developed } & \multicolumn{2}{|c|}{$\frac{\text { Medium developed }}{\text { Weighted }}$} & \multicolumn{2}{|c|}{ Developed } & \multicolumn{2}{|c|}{ Metropolitan } \\
\hline & $\begin{array}{l}\text { Weighte } \\
\text { total }\end{array}$ & Women & $\begin{array}{l}\text { Weigh } \\
\text { total }\end{array}$ & Women & $\begin{array}{l}\text { Weigh } \\
\text { total }\end{array}$ & Women & $\begin{array}{l}\text { Weigh } \\
\text { total }\end{array}$ & d Women \\
\hline Help in housework & 11.1 & 13.9 & 13.7 & 13.8 & 6.1 & 8.8 & 3.7 & 5.0 \\
\hline Help in old age & 39.5 & 43.2 & 41.8 & 41.5 & 36.0 & 35.3 & 23.0 & 24.9 \\
\hline Financial and practical help & 24.7 & 27.0 & 22.4 & 21.1 & 17.9 & 16.2 & 11.2 & 11.0 \\
\hline Family name or line, social obligations & 24.1 & 15.0 & 24.3 & 16.2 & 23.8 & 12.4 & 15.5 & 9.5 \\
\hline Benefit for the marriage & 10.1 & 16.6 & 12.9 & 11.1 & 12.4 & 13.5 & 16.9 & 15.0 \\
\hline Adult status, social norms & 10.3 & 9.2 & 16.2 & 15.1 & 15.6 & 13.3 & 16.6 & 16.6 \\
\hline $\begin{array}{l}\text { Companionship, love, avoidance of } \\
\text { loneliness }\end{array}$ & 11.3 & 19.1 & 17.9 & 19.0 & 15.4 & 22.1 & 28.6 & 33.0 \\
\hline $\begin{array}{l}\text { Happiness for family, fun at home, } \\
\text { amusement }\end{array}$ & 20.9 & 19.3 & 22.1 & 18.5 & 25.0 & 21.7 & 29.2 & 27.7 \\
\hline Living through children & 1.3 & 2.2 & 3.4 & 1.8 & 2.4 & 1.7 & 4.3 & 3.7 \\
\hline Achievement, power over children & 6.7 & 5.4 & 7.9 & 12.2 & 9.5 & 8.5 & 14.4 & 16.1 \\
\hline $\begin{array}{l}\text { Character, fulfillment, responsibility, } \\
\text { maturity, learning experience }\end{array}$ & 3.0 & 1.2 & 5.8 & 5.8 & 9.5 & 6.9 & 10.1 & 9.7 \\
\hline Miscellaneous ${ }^{\mathbf{a}}$ & 18.2 & 14.9 & 17.2 & 18.8 & 23.3 & 22.9 & 29.9 & 28.8 \\
\hline
\end{tabular}

a Includes the response "Unable to think of any advantages." 
whereas financial and practical help from children had a negative association with development. These patterns of association provide support to our proposition that different values are differentially affected by development.

The association between values of children and family income established by the study is less clear-cut. A positive linear relationship was found between the companionship provided by children and income. Other psychological values, such as living through children and the contribution of children to character development and sense of responsibility, were also positively associated with income, though these values were not stressed much even by respondents with higher incomes. Unexpectedly, we found no relationship, positive or negative, between income level and economic values of children. These findings suggest that in Turkey income is not a factor that greatly affects the value of children. By itself, income does not appear to be a good indicator of socioeconomic status, for it probably reflects only cash income and not income in goods.

We found the relationship between education and values of children to be more marked (Table 16). Economic and utilitarian values like help with house work and financial and practical help were less salient to respondents with more education than to others. Old-age security was salient even among respondents with a high school education and among university-educated women, but not so for men educated at the university level. University education seems to have played a key role in changing other values as well, particularly in increasing the social value of children for reinforcing adult status and social norms, and in heightening such psychological values as providing companionship, achievement, and a sense of fulfillment or responsibility.

Women's educational level appears to have been an even more important indicator of value salience than men's. For example, help from children in old age was more salient to women than to men with either no education or a university education, but the pattern was reversed among those who had attended high school. Companionship from children was twice as salient to women with a high level of education as to those with no schooling; for men educational level made less difference in the salience of this value. As the general level of education was very low for the women, having some education made more of a difference for them than it did for men.

Associations between women's work status and occupations on one 
TABLE 16 Advantages of having children, by educational level (Percentages of respondents mentioning specified advantages)

\begin{tabular}{|c|c|c|c|c|c|c|c|c|c|c|c|c|}
\hline \multirow[b]{2}{*}{ Advantage } & \multicolumn{4}{|c|}{ Women } & \multicolumn{4}{|l|}{ Men } & \multicolumn{4}{|c|}{ Weighted total } \\
\hline & $\begin{array}{l}\text { No } \\
\text { edu- } \\
\text { cation }\end{array}$ & $\begin{array}{l}\text { Pri- } \\
\text { mary } \\
\text { school }\end{array}$ & $\begin{array}{l}\text { High } \\
\text { school }\end{array}$ & $\begin{array}{l}\text { Uni- } \\
\text { versity } \\
\text { and } \\
\text { above }\end{array}$ & $\begin{array}{l}\text { No } \\
\text { edu- } \\
\text { cation }\end{array}$ & $\begin{array}{l}\text { Pri- } \\
\text { mary } \\
\text { school }\end{array}$ & $\begin{array}{l}\text { High } \\
\text { school }\end{array}$ & $\begin{array}{l}\text { Uni- } \\
\text { versity } \\
\text { and } \\
\text { above }\end{array}$ & $\begin{array}{l}\text { No } \\
\text { edu- } \\
\text { cation }\end{array}$ & $\begin{array}{l}\text { Pri- } \\
\text { mary } \\
\text { school }\end{array}$ & $\begin{array}{l}\text { High } \\
\text { school }\end{array}$ & $\begin{array}{l}\text { Uni- } \\
\text { versity } \\
\text { and } \\
\text { above }\end{array}$ \\
\hline Help in housework & 12.4 & 12.5 & 3.7 & 0.0 & 6.8 & 8.5 & 7.6 & 1.0 & 9.6 & 10.5 & 5.6 & 0.5 \\
\hline Help in old age & 36.9 & 42.3 & 29.8 & 20.7 & 25.0 & 42.4 & 33.3 & 3.3 & 31.0 & 42.4 & 31.6 & 12.0 \\
\hline Financial and practical help & 25.8 & 18.4 & 7.1 & 8.9 & 24.6 & 24.2 & 15.1 & 7.3 & 25.2 & 21.3 & 11.1 & 7.2 \\
\hline $\begin{array}{l}\text { Family name or line, social } \\
\text { obligations }\end{array}$ & 14.5 & 12.4 & 19.1 & 7.7 & 41.2 & 31.1 & 30.0 & 36.1 & 27.8 & 21.8 & 24.6 & 21.9 \\
\hline Benefit for the marriage & 15.2 & 13.0 & 13.1 & 12.7 & 14.0 & 10.3 & 10.9 & 10.4 & 14.6 & 11.6 & 12.0 & 11.6 \\
\hline Adult status, social norms & 9.8 & 12.9 & 22.1 & 42.6 & 3.6 & 16.3 & 16.2 & 28.9 & 6.7 & 14.6 & 19.2 & 35.8 \\
\hline $\begin{array}{l}\text { Companionship, love, avoidance } \\
\text { of loneliness }\end{array}$ & 16.8 & 23.7 & 31.7 & 35.0 & 11.8 & 10.0 & 12.1 & 21.7 & 14.3 & 16.8 & 21.9 & 28.4 \\
\hline $\begin{array}{l}\text { Happiness for family, fun at } \\
\text { home, amusement }\end{array}$ & 17.8 & 22.3 & 26.3 & 26.8 & 9.6 & 27.5 & 29.0 & 26.7 & 13.7 & 24.9 & 27.6 & 26.8 \\
\hline Living through children & 1.9 & 1.9 & 3.3 & 4.7 & 0.8 & 1.9 & 5.0 & 10.0 & 1.4 & 1.9 & 4.2 & 7.4 \\
\hline Achievement, power over children & 6.9 & 10.3 & 15.2 & 25.2 & 14.5 & 4.0 & 9.6 & 29.9 & 10.7 & 7.2 & 12.4 & 27.6 \\
\hline $\begin{array}{l}\text { Character, fulfillment, responsibil- } \\
\text { ity, maturity, learning experience }\end{array}$ & 3.1 & 5.0 & 12.5 & 20.1 & 0.0 & 10.0 & 4.7 & 19.8 & 1.6 & 7.5 & 8.6 & 20.0 \\
\hline Miscellaneous ${ }^{\mathrm{a}}$ & 19.2 & 18.2 & 28.7 & 31.6 & 15.5 & 15.0 & 32.5 & 39.7 & 17.4 & 16.6 & 30.6 & 35.7 \\
\hline
\end{tabular}

NOTE: For primary and high school, educational level represents completed level. For university and above, level means either attendance or completion.

a Includes the response "Unable to think of any advantages." 
TABLE 17 Advantages of having children, by women's work status (Percentages of women mentioning specific advantages)

Occupation

\begin{tabular}{|c|c|c|c|c|}
\hline \multirow[b]{2}{*}{ Advantage } & \multicolumn{2}{|c|}{ Working or not } & \multirow{2}{*}{$\begin{array}{l}\text { Unclas- } \\
\text { sified } \\
(7.2) \\
\end{array}$} & \multirow{2}{*}{$\begin{array}{l}\text { Family } \\
\text { workers } \\
(34.7)\end{array}$} \\
\hline & No & Yes & & \\
\hline Help in housework & 6.1 & 16.4 & 7.4 & 12.8 \\
\hline Help in old age & 35.0 & 40.2 & 31.3 & 47.9 \\
\hline Financial and practical help & 17.2 & 23.3 & 16.9 & 17.9 \\
\hline Family name or line, social obligations & 13.3 & 14.1 & 15.9 & 17.8 \\
\hline Benefit for the marriage & 16.8 & 11.2 & 13.2 & 13.2 \\
\hline Adult status, social norms & 15.2 & 11.0 & 21.0 & 10.5 \\
\hline $\begin{array}{l}\text { Companionship, love, avoidance of } \\
\text { loneliness }\end{array}$ & 25.0 & 19.0 & 27.0 & 17.4 \\
\hline $\begin{array}{l}\text { Happiness for family, fun at home, } \\
\text { amusement }\end{array}$ & 23.8 & 18.1 & 28.4 & 12.4 \\
\hline Living through children & 2.8 & 1.7 & 0.0 & 2.6 \\
\hline Achievement, power over children & 11.6 & 8.4 & 11.1 & 7.1 \\
\hline $\begin{array}{l}\text { Character, fulfillment, responsibility, } \\
\text { maturity, learning experience }\end{array}$ & 6.3 & 3.8 & 8.0 & 4.8 \\
\hline Miscellaneous ${ }^{b}$ & 21.5 & 19.3 & 18.1 & 17.5 \\
\hline
\end{tabular}

a Includes pensioners and part-time workers at home.

b Includes the response "Unable to think of any advan tages."

hand and their perceptions of the advantages of having children on the other are presented in Table 17. Working women stressed old-age security, financial and practical help, and help in housework. Nonworking women in contrast tended to emphasize psychological and social values of children. If women's employment is considered to be an indicator of socioeconomic development, these findings are counterevidence for hypothesis 3 (that the psychological value of children increases with development). However; the type of work done by women needs to be considered because, as reported earlier, even though more than half of the VOC women did work other than 
and occupation

\begin{tabular}{|c|c|c|c|c|c|c|c|c|}
\hline $\begin{array}{l}\text { Un- } \\
\text { skilled } \\
\text { labor- } \\
\text { ers } \\
(13.5) \\
\end{array}$ & $\begin{array}{l}\text { Semi- } \\
\text { skilled } \\
\text { labor- } \\
\text { ers } \\
(0.9) \\
\end{array}$ & $\begin{array}{l}\text { Skilled } \\
\text { labor- } \\
\text { ers } \\
(2.3) \\
\end{array}$ & $\begin{array}{l}\text { Small } \\
\text { entre- } \\
\text { pren- } \\
\text { eurs, } \\
\text { farm- } \\
\text { ers } \\
(34.7)\end{array}$ & $\begin{array}{l}\text { Civil } \\
\text { ser- } \\
\text { vants, } \\
\text { middle- } \\
\text { rank- } \\
\text { ing } \\
\text { employ- } \\
\text { ees } \\
(4.7) \\
\end{array}$ & $\begin{array}{l}\text { Tech- } \\
\text { ni- } \\
\text { cians, } \\
\text { oper- } \\
\text { ators } \\
(0.6) \\
\end{array}$ & $\begin{array}{l}\text { Offi- } \\
\text { cials, } \\
\text { mana- } \\
\text { gers } \\
(0.4) \\
\end{array}$ & $\begin{array}{l}\text { Entre- } \\
\text { pren- } \\
\text { eurs } \\
(0.1) \\
\end{array}$ & $\begin{array}{l}\text { Profes- } \\
\text { sionals } \\
(0.7) \\
\end{array}$ \\
\hline 11.4 & 0.0 & 2.7 & 24.0 & 3.1 & 0.0 & 0.0 & 0.0 & 0.0 \\
\hline 33.4 & 20.7 & 26.5 & 43.6 & 18.1 & 32.2 & 13.3 & 0.0 & 42.1 \\
\hline 26.6 & 0.0 & 26.9 & 30.4 & 7.4 & 0.0 & 0.0 & 0.0 & 21.5 \\
\hline 11.8 & 29.9 & 5.1 & 9.6 & 16.7 & 0.0 & 11.6 & 0.0 & 20.6 \\
\hline 10.9 & 15.0 & 14.6 & 8.2 & 14.8 & 0.0 & 0.0 & $0.0^{\circ}$ & 7.1 \\
\hline 12.1 & 17.1 & 33.0 & 5.2 & 30.1 & 45.2 & 61.8 & 46.5 & 18.4 \\
\hline 26.8 & 40.2 & 22.6 & 16.1 & 32.5 & 72.7 & 24.8 & 53.5 & 44.8 \\
\hline 11.8 & 30.5 & 18.0 & 23.3 & 28.4 & 38.3 & 16.8 & 0.0 & 21.5 \\
\hline 1.8 & 5.0 & 2.7 & 0.6 & 5.3 & 0.0 & 0.0 & 0.0 & 8.1 \\
\hline 9.6 & 17.1 & 13.1 & 6.3 & 16.0 & 21.2 & 24.8 & 0.0 & 32.5 \\
\hline 2.5 & 5.8 & 9.5 & 1.6 & 13.0 & 6.1 & 28.3 & 53.5 & 18.4 \\
\hline 23.9 & 31.0 & 8.7 & 14.5 & 38.0 & 54.2 & 28.3 & 0.0 & 23.3 \\
\hline
\end{tabular}

housework, only 30 percent were cash earners, and thus what constituted their "work" is not clear. Furthermore, as female education and consequently occupational specialization levels were low in our sample, their working may have resulted from economic necessity rather than socioeconomic development. In this context, the types of advantages VOC women ascribed to children make sense.

A few associations between values of children and women's and men's occupations deserve mention. Among women (Table 17), the old-age security provided by children was mentioned most frequently by unpaid family workers and somewhat less frequently by small 
entrepreneurs (shop owners and artisans), who are typically a "traditional" group. Contrary to expectation, it was also quite salient to professional women-more so, in fact, than to other white-collar or to blue-collar women. This finding should be regarded with caution, however, because of the small number of professional women in the sample. Among men (Table 18), old-age security had greatest salience for an unclassified group that included pensioners and members of the armed forces, and for small entrepreneurs and farmers, unskilled workers, and skilled laborers. It had no salience for officials and managers, and little for larger entrepreneurs. Except for these, clear-cut patterns did not emerge.

To summarize, the cross-tabulations examined thus far support our hypothesis that with socioeconomic development, the values of oldage security and material help from children lose importance and the psychological value of children grows in importance, especially for women. The apparent effect of education, and especially women's education, on the types of values derived from children is notable. And occupational level is negatively associated with the old-age security value of children.

Additional analysis revealed that specific values associated with boy preference are related in the VOC data to socioeconomic development and socioeconomic status in a way supporting hypothesis 3 . The importance of economic reasons for wanting a boy, especially material help and old-age security, appears to decrease with development and education (Tables 19 and 20). The value of sons for carrying on the family name and meeting social obligations, however, was positively related to development and education in our sample, though university education seems to have had a dampening effect on its salience, at least among wives.

Several differences between men and women are apparent in these associations. The inverse relationship between the salience of sons' oldage security value and development was pronounced among men but not so among women (Table 19). This finding suggests that, whatever their development stratum, Turkish women feel a greater need for oldage support from their sons than do men. In contrast, for both men and women, the more developed was their area of residence, the less salient was the value of sons' financial or practical help while young. Carrying on the family name, a social value of sons, was highly salient to men regardless of development level. The companionship value of sons gained in salience with development, especially for women. 


\begin{tabular}{|c|c|c|c|c|c|c|c|c|c|c|}
\hline Advantage & $\begin{array}{l}\text { Unclas- } \\
\text { sified } \\
(1.5) \\
\end{array}$ & $\begin{array}{l}\text { Un- } \\
\text { skilled } \\
\text { labor- } \\
\text { ers } \\
(17.5) \\
\end{array}$ & $\begin{array}{l}\text { Semi- } \\
\text { skilled } \\
\text { labor- } \\
\text { ers } \\
(5.6) \\
\end{array}$ & $\begin{array}{l}\text { Skilled } \\
\text { labor- } \\
\text { ers } \\
(9.2) \\
\end{array}$ & $\begin{array}{l}\text { Small } \\
\text { entre- } \\
\text { pren- } \\
\text { eurs, } \\
\text { farm- } \\
\text { ers } \\
(48.1) \\
\end{array}$ & $\begin{array}{l}\text { Civil } \\
\text { ser- } \\
\text { vants, } \\
\text { middle- } \\
\text { rank- } \\
\text { ing } \\
\text { employ- } \\
\text { ees } \\
\text { (10.7) } \\
\end{array}$ & $\begin{array}{l}\text { Tech- } \\
\text { Ti- } \\
\text { cians, } \\
\text { oper- } \\
\text { ators } \\
\text { (1.6) } \\
\end{array}$ & $\begin{array}{l}\text { Offi- } \\
\text { cials, } \\
\text { mana- } \\
\text { gers } \\
(1.4) \\
\end{array}$ & $\begin{array}{l}\text { Entre- } \\
\text { pren- } \\
\text { eurs } \\
(3.6) \\
\end{array}$ & $\begin{array}{l}\text { Profes- } \\
\text { sionals } \\
(1.7) \\
\end{array}$ \\
\hline Help in housework & 0.0 & 14.2 & 10.8 & 1.5 & 7.4 & 0.0 & 9.7 & 0.0 & 14.7 & 0.0 \\
\hline Help in old age & 56.6 & 36.2 & 26.0 & 34.3 & 41.6 & 24.7 & 18.6 & 0.0 & 2.9 & 8.8 \\
\hline Financial, practical help & 0.0 & 25.7 & 5.3 & 16.1 & 22.7 & 11.0 & 0.0 & 7.1 & 11.8 & 15.4 \\
\hline $\begin{array}{l}\text { Family name or line, social } \\
\text { obligations }\end{array}$ & 32.5 & 23.4 & 28.6 & 22.8 & 34.8 & 49.5 & 36.0 & 47.9 & 51.0 & 32.1 \\
\hline Benefit for the marriage & 14.3 & 121 & 10.6 & 26.3 & 9.2 & 10.8 & 29.2 & 15.7 & 18.7 & $12: 2$ \\
\hline Adult status, social norms & 13.5 & 12.9 & 26.1 & 22.4 & 10.8 & 23.8 & 28.4 & 27.8 & 20.4 & 23.7 \\
\hline $\begin{array}{l}\text { Companionship, love, avoidance } \\
\text { of loneliness }\end{array}$ & 13.0 & 9.3 & 32.5 & 21.2 & 8.1 & 9.5 & 20.3 & 29.4 & 19.4 & 28.1 \\
\hline $\begin{array}{l}\text { Happiness for family, fun at } \\
\text { home, amusement }\end{array}$ & 9.8 & 23.3 & 27.6 & 39.2 & 25.0 & 33.6 & 57.3 & 11.1 & 26.8 & 19.4 \\
\hline Living through children & 0.0 & 1.5 & 0.0 & 4.0 & 1.9 & 6.8 & 0.0 & 18.1 & 9.0 & 5.6 \\
\hline Achievement, power over children & 16.9 & 14.7 & 0.0 & 7.7 & 3.4 & 9.7 & 0.0 & 20.1 & 10.7 & 35.4 \\
\hline $\begin{array}{l}\text { Character, fulfillment, responsibil- } \\
\text { ity, maturity, learning experience }\end{array}$ & 0.0 & 5.2 & 6.2 & 17.2 & 8.3 & 3.8 & 8.9 & 17.4 & 22.6 & 14.4 \\
\hline Miscellaneous $^{\mathrm{b}} \quad \cdots$ & 30.4 & 14.1 & 22.9 & 17.9 & 18.0 & 27.5 & 14.1 & 27.2 & 37.1 & $46: 8$ \\
\hline
\end{tabular}

a Includes pensioners and men in the military.

b Includes the response "Unable to think of any advantages." 
TABLE 19 Reasons for wanting sons, by development stratum

(Percentages of respondents mentioning specific reasons)

\begin{tabular}{|c|c|c|c|c|c|c|c|c|}
\hline \multirow[b]{2}{*}{ Reason } & \multicolumn{4}{|c|}{ Women } & \multicolumn{4}{|l|}{ Men } \\
\hline & $\begin{array}{l}\text { Least } \\
\text { devel- } \\
\text { oped }\end{array}$ & $\begin{array}{l}\text { Inter- } \\
\text { mediate }\end{array}$ & $\begin{array}{l}\text { Devel- } \\
\text { oped }\end{array}$ & $\begin{array}{l}\text { Metro- } \\
\text { politan }\end{array}$ & $\begin{array}{l}\text { Least } \\
\text { devel- } \\
\text { oped }\end{array}$ & $\begin{array}{l}\text { Inter- } \\
\text { mediate }\end{array}$ & $\begin{array}{l}\text { Devel- } \\
\text { oped }\end{array}$ & $\begin{array}{l}\text { Metro- } \\
\text { politan }\end{array}$ \\
\hline Help in housework & 5.7 & 5.3 & 4.0 & 1.2 & 1.1 & 4.4 & 4.5 & 2.8 \\
\hline Help in old age & 38.0 & 38.1 & 38.3 & 31.8 & 45.4 & 30.4 & 33.4 & 18.5 \\
\hline Financial, practical help & 50.4 & 42.2 & 32.1 & 30.0 & 61.2 & 37.9 & 32.1 & 22.9 \\
\hline Family name or line, social obligations & 23.5 & 23.4 & 36.0 & 33.8 & 46.6 & 54.4 & 51.2 & 55.5 \\
\hline Benefit for the marriage & 0.2 & 0.5 & 0.5 & 4.4 & 0.5 & 0.3 & 0.0 & 0.8 \\
\hline Companionship, love, avoidance of loneliness & 26.0 & 31.6 & 39.9 & 39.1 & 18.0 & 29.6 & 24.9 & 22.2 \\
\hline Companion for child/ren & 2.0 & 0.0 & 0.3 & 1.4 & 0.0 & 0.0 & 0.0 & 0.0 \\
\hline Living through children & 2.6 & 4.9 & 5.2 & 1.9 & 0.6 & 2.0 & 2.1 & 2.5 \\
\hline Achievement, power over children & 13.7 & 10.4 & 4.9 & 7.0 & 7.2 & 9.8 & 5.3 & 8.1 \\
\hline $\begin{array}{l}\text { Character, fulfillment, responsibility, } \\
\text { maturity, learning experience }\end{array}$ & 0.0 & 1.0 & 0.6 & 1.2 & 0.5 & 0.0 & 1.9 & 0.8 \\
\hline Sons easier to raise & 11.1 & 13.5 & 5.7 & 13.0 & 4.2 & 10.6 & 9.1 & 16.3 \\
\hline Miscellaneous & 6.1 & 6.7 & 7.0 & 8.0 & 6.2 & 2.7 & 5.8 & 11.5 \\
\hline
\end{tabular}


TABLE 20 Reasons for wanting sons, by educational level

(Percentages of respondents mentioning specific reasons)

\begin{tabular}{|c|c|c|c|c|c|c|c|c|}
\hline \multirow[b]{2}{*}{ Reason } & \multicolumn{4}{|l|}{ Women } & \multicolumn{4}{|l|}{ Men } \\
\hline & $\begin{array}{l}\text { No } \\
\text { educa- } \\
\text { tion }\end{array}$ & $\begin{array}{l}\text { Pri- } \\
\text { mary } \\
\text { school }\end{array}$ & $\begin{array}{l}\text { High } \\
\text { school }\end{array}$ & $\begin{array}{l}\text { Univer- } \\
\text { sity and } \\
\text { above }\end{array}$ & $\begin{array}{l}\text { No } \\
\text { educa- } \\
\text { tion }\end{array}$ & $\begin{array}{l}\text { Pri- } \\
\text { mary } \\
\text { school }\end{array}$ & $\begin{array}{l}\text { High } \\
\text { school }\end{array}$ & $\begin{array}{l}\text { Univer- } \\
\text { sity and } \\
\text { above }\end{array}$ \\
\hline Help in housework & 6.3 & 4.0 & 0.4 & 0.0 & 8.9 & 1.7 & 2.9 & 4.6 \\
\hline Help in old age & 38.7 & 39.7 & 25.6 & 6.1 & 57.6 & 30.4 & 35.6 & 38.3 \\
\hline Financial and practical help & 46.9 & 38.7 & 25.7 & 14.6 & 39.6 & 63.6 & 42.1 & 36.6 \\
\hline Family name or line, social obligations & 20.2 & 31.6 & 46.8 & 38.2 & 48.4 & 57.7 & 44.6 & $59.8^{\circ}$ \\
\hline Benefit for the marriage & 0.0 & 0.8 & 2.5 & 14.4 & 0.0 & 0.0 & 0.3 & 0.3 \\
\hline Companionship, love, avoidance of loneliness & 30.2 & 34.0 & 40.2 & 33.1 & 20.8 & 34.7 & 23.5 & 21.5 \\
\hline Companion for child/ren & 1.4 & 0.1 & 1.9 & 4.0 & 0.0 & 0.0 & 0.0 & 0.0 \\
\hline Living through children & 3.5 & 4.8 & 1.5 & 0.0 & 0.7 & 1.1 & 1.6 & 1.3 \\
\hline Achievement, power over children & 13.0 & 6.3 & 9.2 & 5.6 & 2.1 & 9.3 & 6.8 & 7.2 \\
\hline $\begin{array}{l}\text { Character, fulfillment, responsibility, } \\
\text { maturity, learning experience }\end{array}$ & 0.7 & 0.2 & 1.3 & 3.7 & 0.0 & 2.6 & 0.8 & 0.0 \\
\hline Sons easier to raise & 11.2 & 9.7 & 10.3 & 22.0 & 8.4 & 0.0 & 9.1 & 8.4 \\
\hline Miscellaneous & 5.1 & 7.4 & 10.2 & 12.7 & 7.7 & 3.9 & 3.4 & 8.3 \\
\hline
\end{tabular}


The inverse association between sons' old-age security value and education was much more pronounced among women than men. Thus, women's education again appears to be a key indicator of value changes. The companionship value of sons, a psychological value, increased in salience with women's education but showed no clear pattern for men. Thus, although in general the salience of economic/ utilitarian reasons for wanting boys was negatively associated with educational level, that of companionship had a positive association, at least for women, partially supporting hypothesis 3 . The greater companionship value of sons among more educated women may have been a compensation for sons' greatly diminished economic value.

It is worth noting that in the metropolitan areas (Table 19) and among more educated women (Table 20 ) the greater ease of raising sons gained salience as a reason for wanting sons. In general, however, rearing sons was considered to entail more economic and emotional costs than rearing daughters.

Associations between the three value factors (economic/utilitarian, psychological, and social/normative) derived from factor analysis of reasons for wanting another child and the two indicators of socioeconomic development (rural/urban residence and development stratum) are presented in Table 21 . The rural/urban dimension reveals that the economic/utilitarian value factor was more important in rural than in urban settings for both women and men, but in both settings was more important to women than to men. The psychological value factor, however, was of greater importance in urban than in rural areas for men, though it was more important to women than to men regardless of the setting. These findings tend to support hypothesis 3. Similarly, Table 21 shows meaningful associations between the empirically derived value factors and level of development. Respondents, especially women, living in less developed areas attached more importance to economic/utilitarian reasons for wanting another child than did those in more developed areas. In contrast, the correlations imply that the importance of psychological values of another child increased with development, though the change was less dramatic than that for the economic value. For men there was no association between development stratum and the social/normative value factor, but for women the importance of the social/normative value was inversely associated with development. These findings, showing meaningful relations in the expected direction between development stratum and the three value factors, provide additional support for hypothesis 3 . 
Through correlation analysis we examined relations among background development variables, values of children, and fertility variables. We formed three VOC indices by combining the three VOC factors, which were derived from factor analysis of the ranked importance of reasons for wanting another child, with appropriate items from another structured question on the ranked importance of reasons for wanting children in general. Together with several other indices to be explained below, these were put into a correlation matrix based on responses by women only (Table 22). The following discussion, pertaining to hypothesis 3 , and subsequent discussions of other findings draw upon this correlation matrix, but I will also refer to other single correlation coefficients not shown in the table when they are relevant.

The following indices were developed for the correlation matrix:

1. Psychological VOC index: obtained by combining the psychological factor derived from the factor analysis of reasons for wanting another child and the psychological advantages of children in general.

2. Social/normative VOC index: obtained by combining the social/ normative reasons for wanting another child and the social/normative advantages of children in general.

3. Economic/utilitarian VOC index: obtained by combining the economic/utilitarian reasons for wanting another child with the economic/utilitarian advantages of children in general. It includes material help from children while they are young and old-age security provided by grown children.

4. Opportunity cost index: derived from three questions dealing with limitations imposed by children on parents' work and leisure activities.

5. Economic expectations index: obtained by combining various expectations of economic help from sons and daughters and the level of those expectations.

6. Woman's status index: obtained by combining scores on couples' decision-making, communication, and role sharing.

7. Development-population index: obtained by combining the development levels and population criteria on which the stratification of the sample was based.

Other variables in Table 22 were operationalized as follows: Development stratum, representing the four levels of development (from least to most developed, or metropolitan), was scored from 1 to 4 . It is a less precise measure of development than the development-population index. Son preference was measured by Coombs et al. (1975) unfolding 
TABLE 21 Value factors, by development stratum and rural/urban (Percentages of respondents rating values as important)

\begin{tabular}{|c|c|c|c|c|c|c|}
\hline \multirow[b]{3}{*}{ Value factor } & \multicolumn{6}{|c|}{ Development stratum } \\
\hline & \multicolumn{3}{|l|}{ Rural } & \multicolumn{3}{|c|}{ Population $2,000-10,000$} \\
\hline & $\begin{array}{l}\text { Least de- } \\
\text { veloped }\end{array}$ & $\begin{array}{l}\text { Inter- } \\
\text { mediate }\end{array}$ & $\begin{array}{l}\text { Devel- } \\
\text { oped }\end{array}$ & $\begin{array}{l}\text { Least de- } \\
\text { veloped }\end{array}$ & $\begin{array}{l}\text { Inter- } \\
\text { mediate }\end{array}$ & $\begin{array}{l}\text { Devel- } \\
\text { oped }\end{array}$ \\
\hline \multicolumn{7}{|c|}{ ECONOMIC/UTILITARIAN } \\
\hline \multicolumn{7}{|l|}{ Women } \\
\hline Important & 80.3 & 42.9 & 58.5 & 61.0 & 47.8 & 45.7 \\
\hline Not important & \multicolumn{6}{|c|}{$\chi^{2}=247.11, p<.001, N=1,762$} \\
\hline \multicolumn{7}{|l|}{ Men } \\
\hline Important & 50.0 & 27.3 & 42.4 & 64.7 & 39.1 & 34.5 \\
\hline Not important & \multicolumn{6}{|c|}{$\chi^{2}=37.04, p<.001, \mathrm{~N}=543$} \\
\hline \multicolumn{7}{|l|}{ PSYCHOLOGICAL } \\
\hline \multicolumn{7}{|l|}{ Women } \\
\hline Important & 45.1 & 42.1 & 45.8 & 51.0 & 37.5 & 53.2 \\
\hline Not important & \multicolumn{6}{|c|}{$\chi^{2}=24.84, p<01, \mathrm{~N}=1,762$} \\
\hline \multicolumn{7}{|l|}{ Men } \\
\hline Important & 20.8 & 43.2 & 33.3 & 61.8 & 50.0 & 48.3 \\
\hline Not important & \multicolumn{6}{|c|}{$\chi^{2}=26.15, p<.01, N=543$} \\
\hline \multicolumn{7}{|c|}{ SOCIAL/NORMATIVE } \\
\hline \multicolumn{7}{|l|}{ Women } \\
\hline Important & 46.5 & 38.3 & 37.3 & 51.0 & 33.1 & 37.2 \\
\hline Not important & \multicolumn{6}{|c|}{$\chi^{2}=24.44, p<.01, N=1,762$} \\
\hline \multicolumn{7}{|l|}{ Men } \\
\hline Important & 33.3 & 38.6 & 39.4 & 58.8 & 43.5 & 37.9 \\
\hline Not important & $\begin{array}{l}66.7 \\
\chi^{2}=8.66\end{array}$ & $\begin{array}{c}61.4 \\
N=543\end{array}$ & 60.6 & 41.2 & 56.5 & 62.1 \\
\hline
\end{tabular}

NOTE: Percentages may not sum to 100 because of rounding. 
residence

\section{Urban}

Least de- Inter- Develveloped

oped
59.6

40.4

$\begin{array}{lll}36.1 & 34.4 & 27.2 \\ 63.9 & 65.6 & 72.8\end{array}$

$\begin{array}{lll}62.4 & 49.0 & 56.0\end{array}$

$\begin{array}{lll}37.6 & 51.0 \quad 44.0\end{array}$

46.2

53.8
38.9

61.1

66.7

23.3

76.7

14.4

85.6
Residence

Rural Urban
Whole Sample 
TABLE 22 Correlation matrix of background, intervening, and

\begin{tabular}{|c|c|c|c|}
\hline \multirow[b]{2}{*}{ Background and intervening variables ${ }^{\mathrm{a}}$} & \multicolumn{3}{|c|}{ Dependent variables } \\
\hline & $\begin{array}{l}\text { Desired } \\
\text { number of } \\
\text { children }\end{array}$ & $\begin{array}{l}\text { Ideal } \\
\text { number of } \\
\text { children }\end{array}$ & $\begin{array}{l}\text { Birth } \\
\text { control } \\
\text { practice }\end{array}$ \\
\hline Parity & .59 & .22 & .21 \\
\hline Son preference & .23 & .20 & $(-.06$ \\
\hline Psychological VOC* & -.14 & $(-.04$ & -.11 \\
\hline Social/normative VOC* & .29 & .20 & -.18 \\
\hline Economic/utilitarian VOC* & .31 & .20 & -.19 \\
\hline Woman's status & $(.02)$ & $(-.04)$ & $(.04)$ \\
\hline Belief in internal control & -.17 & -.10 & .11 \\
\hline Economic expectation* & .22 & .11 & -.11 \\
\hline Education & -.37 & -.26 & .15 \\
\hline Husband's education & -.33 & -.22 & .13 \\
\hline Income & -.22 & -.16 & .11 \\
\hline Marriage duration & .29 & .25 & .18 \\
\hline Exposure to mass media & -.20 & -.14 & .12 \\
\hline Development-population* & -.26 & -.15 & .12 \\
\hline Development stratum & -.17 & $(-.07)$ & .10 \\
\hline$\%$ urban experience & -.15 & -.16 & .12 \\
\hline
\end{tabular}

NOTE: Figures within parentheses indicate nonsignificant correlations.

* Index. For definition, see text.

a Intervening variables are also treated as independent and dependent variables, but not

technique, which required respondents to indicate their sex preferences for given hypothetical numbers of children. Exposure to mass media was measured by frequency of exposure, with scores ranging from 1 to 10.1(For more information about these measurements, see VOC Technical Notes No. 5, The Questionnaire, and No. 2, VOC Comparative Codebook $B$, issued by the East-West Population Institute.)

No significant correlations emerged between the two development variables and psychological values of children, contrary to hypothesis 3 ; but development was negatively correlated with social/normative values and even more so with economic/utilitarian values, as expected (Table 22). Negative correlations were also found between the social/ normative and economic/utilitarian values on the one hand, and other indicators of general level of development on the other, such as urban 
dependent variables, including indices: women

\begin{tabular}{|c|c|c|c|c|c|c|}
\hline \multicolumn{7}{|c|}{ Intervening variables ${ }^{\mathrm{a}}$} \\
\hline Parity & $\begin{array}{l}\text { Son } \\
\text { prefer- } \\
\text { ence }\end{array}$ & $\begin{array}{l}\text { Psycho- } \\
\text { logical } \\
\text { VoC* }\end{array}$ & $\begin{array}{l}\text { Social/ } \\
\text { normative } \\
\text { VOC* }\end{array}$ & $\begin{array}{l}\text { Economic/ } \\
\text { utilitarian } \\
\text { vOC* }\end{array}$ & $\begin{array}{l}\text { Woman's } \\
\text { status }\end{array}$ & $\begin{array}{l}\text { Belief in } \\
\text { internal } \\
\text { control }\end{array}$ \\
\hline & .21 & -.19 & .12 & .14 & $(-.02)$ & -.17 \\
\hline .21 & & .12 & .29 & .25 & -.12 & -.18 \\
\hline-.19 & .12 & & .53 & .48 & -.13 & -.15 \\
\hline .12 & .29 & .53 & & .64 & -.17 & -.36 \\
\hline .14 & .25 & .48 & .64 & & -.16 & -.30 \\
\hline$(-.02)$ & -.12 & -.13 & -.17 & -.16 & & .16 \\
\hline-.17 & -.18 & -.15 & -.36 & -.30 & .16 & \\
\hline .22 & .24 & .15 & .43 & .39 & -.19 & -.35 \\
\hline-.41 & -.33 & -.12 & -.45 & -.44 & .23 & .38 \\
\hline-.37 & -.29 & -.11 & -.34 & -.47 & .34 & .37 \\
\hline-.20 & -.16 & $(-.06)$ & -.25 & -.26 & .17 & .29 \\
\hline .66 & $(.05)$ & -.16 & $(.04)$ & $(.08)$ & $(-.02)$ & -.13 \\
\hline-.20 & -.19 & -.13 & -.34 & -.39 & .26 & .36 \\
\hline-.19 & -.17 & $(-.01)$ & -.26 & -.38 & .14 & .17 \\
\hline-.13 & -.08 & $(.02)$ & -.14 & -.21 & $(.01)$ & .14 \\
\hline-.11 & -.13 & $(.00)$ & -.13 & -.16 & .12 & .16 \\
\hline
\end{tabular}

simultaneously.

experience and income; again, no significant correlations with psychological VOCs were apparent. For education and husband's education, however, negative correlations with psychological VOC were evident, contrary to our expectations. This finding indicates a general lessening of values of children with education, though the association is much more marked for social and economic than for psychological values.

The above findings, especially the lessening in importance of economic/utilitarian values of children with development, in general provide support for hypothesis 3 . Some of the analyses also point, though less strongly, to an increase in the salience of psychological values of children. A general modernizing effect of development is thus suggested, associated with parents' decreasing material dependence upon children. 


\section{Socioeconomic development and opportunity costs of children}

The fourth hypothesis predicts an increase in the opportunity cost of children with development. Cross-tabulations between development stratum and various disadvantages of children show that with socioeconomic development, children were more often perceived by men as interfering with parents' freedom (data not shown). The relationship is less clear for women but is apparently there. Children's opportunity cost was stressed most by those who had moved from rural to urban areas, as hypothesized. With increased income, also, the opportunity cost of children became more salient to Turkish respondents, especially at higher income levels.

With increased education and especially with women's increased education, opportunity costs of children became more salient. Women with higher levels of education were also more likely than other women to mention marital strain caused by children. In contrast, although financial costs of children were highly important to women of all educational levels, the salience of this disadvantage decreased with education. The opportunity cost of children was also more salient to working women (those gainfully employed) than to nonworking women.

These findings provide support for hypothesis 4 , suggesting that the perceived opportunity costs of children increase with socioeconomic development as indicated by development stratum, urbanism, education, income, and women's employment. As already indicated, however, the perception of the opportunity cost of children was not widespread in the Turkish sample, particularly among women. When they mentioned this disadvantage, they tended to stress its interference with leisure rather than with work (Table 13). With increased professionalism of women, this disadvantage may be expected to become more salient. Indeed, together with the decreasing importance of economic values of children, the increased opportunity costs of children are assumed to underlie the demographic transition, and our data provide support for this view.

\section{Parity and values of children}

Hypothesis 5 predicts that as parity increases, the economic/utilitarian values of children increase and the psychological values decrease. Parity 
is conceptualized here as an independent variable; in subsequent hypotheses it is considered to be a dependent variable.

The correlations between parity and values of children (Table 22) lend support to hypothesis 5 . Parity was found to have a positive association with economic/utilitarian and with social/normative values of children, including continuation of family name and having a son, but a negative association with psychological values. More specific correlations, including reasons for wanting another child (not shown in Table 22) reveal a negative association between psychological values of children and parity ( $r=-.25$ for women and $r=-.31$ for men).

Cross-tabulations between parity and advantages of children show systematic patterns of relationships (Table 23). Respondents without children remain outside this pattern, however. This may be because, lacking parenthood experience, they probably reflected others' experiences and social norms. As parity rose from one to four and more children, utilitarian values gained in salience.

TABLE 23 Advantages of children, by parity

(Percentages of husbands and wives mentioning specific advantages)

\begin{tabular}{|c|c|c|c|c|c|}
\hline \multirow[b]{2}{*}{ Advantage } & \multicolumn{5}{|l|}{ Parity } \\
\hline & 0 & 1 & 2 & 3 & $4+$ \\
\hline Help in housework & 9.4 & 6.0 & 7.3 & 12.8 & 14.0 \\
\hline Help in old age & 31.9 & 35.4 & 35.6 & 39.0 & 41.8 \\
\hline Financial, practical help & 16.1 & 14.9 & 17.6 & 23.7 & 24.8 \\
\hline Family name or line, social obligations & 16.3 & 17.3 & 19.9 & 20.0 & 17.4 \\
\hline Benefit for the marriage & 12.5 & 10.7 & 14.1 & 14.2 & 13.7 \\
\hline Adult status, social norms & 21.6 & 15.9 & 15.5 & 13.1 & 8.3 \\
\hline $\begin{array}{l}\text { Companionship, love, avoidance of } \\
\text { loneliness }\end{array}$ & 25.8 & 23.2 & 20.7 & 16.3 & 15.3 \\
\hline Play, fun at home, amusement & 20.2 & 30.3 & 21.9 & 23.6 & 17.7 \\
\hline Living through children & 3.1 & 2.3 & 2.3 & 3.0 & 1.7 \\
\hline Achievement, power & 12.9 & 11.7 & 9.4 & 8.4 & 6.7 \\
\hline $\begin{array}{l}\text { Character, fulfillment, responsibility, } \\
\text { maturity, learning experience }\end{array}$ & 5.6 & 7.1 & 9.6 & 5.4 & 2.9 \\
\hline Miscellaneous ${ }^{\mathbf{a}}$ & 28.3 & 22.1 & 20.1 & 20.7 & 16.3 \\
\hline
\end{tabular}

a Includes the response "Unable to think of any advantages." 
Thus, economic/utilitarian values of children appear to be positively associated with family size. In other words, they are cumulative, in the sense that each additional child is a source of additional income, especially at higher parity levels. The psychological values of companionship, love, and avoidance of loneliness, on the other hand, declined in salience with parity.

These findings indicate that psychological values of children do not function in the same cumulative way as economic values, but are, rather, more closely associated with small families. One or two children may provide just as much, or even more, psychological satisfaction to parents as four or more children. The worry and burden of many children may interfere with the psychological satisfactions they provide. For example, the play, fun, and amusement value of children dropped sharply with four or more children (Table 23). These findings support hypothesis 5 .

Though not hypothesized, the social value of children (their providing adult status to parents) appears to be, like psychological values, inversely related to parity. Full social recognition and adult status may be achieved by having a few children, but additional children may not increase this satisfaction. Continuation of the family name, however, does not show a clear association with parity, this social norm keeping its significance at all parity levels (Table 23).

When the above relationships are considered separately for men and women, the patterns appear to be quite similar. Old-age security, the most salient value for both sexes, was mentioned by women even more frequently than by men as parity increased.

Several reasons for wanting another child also varied with parity. Such utilitarian reasons as help in old age and financial or practical help were common reasons for wanting another child among respondents at higher parity levels. Wanting another child in order to have a son and to bring the spouse closer were important at all parities but especially so at lower levels. Having someone to love and care for was a significant reason only for the childless, showing that even one child may satisfy this psychological need. Carrying on the family name was equally important at all parity levels, however.

Thus, various findings provide support for hypothesis 5 , indicating that different values of children are salient at different parities. They 
also point to a mutual feedback mechanism between parity and values of children, to be considered in the discussion of hypothesis 9 .

\section{Parity and costs of children}

Hypothesis 6 states that with increasing parity, the economic costs of children increase but their opportunity costs decrease.

Cross-tabulations between parity and the perceived disadvantages of children provide support for this hypothesis. At higher parities, the economic costs of children were more salient to both men and women than at lower parities. For both men and women, in contrast, the perceived opportunity costs of a child peaked at parity one, and after the first child decreased in salience, especially for women. This decrease in the opportunity cost of additional children has implications for population planning, as it is not a factor restricting numbers of children. With greater professionalism of women, however, the opportunity cost of additional children may increase, especially if births are spaced, as this would tend to delay reentry into the labor force.

\section{Values attributed to sons and daughters}

Hypothesis 7 posits the attribution of different values to sons and daughters and, specifically, the attribution of greater economic value to sons. This hypothesis is based on previous studies of sex-role differentiation in Turkey (e.g., Kandiyoti, 1977; Kagitcibasi, 1973, 1975a, $1979,1982 \mathrm{~b}$ ). It is also consistent with the sex-role differences in the VOC sample and findings related to respondents' basic values.

In the VOC study one question dealt with the contribution of children to basic values (see Table 6). Answers to this question revealed that boys and girls were perceived as contributing rather differently to these basic values. Respondents of both sexes perceived boys to contribute to the satisfaction of a greater number of values and needs than girls (Table 24). Financial security, being accepted by others, having a happy home, personal achievement, and carrying on the family name were all values that respondents associated more with boys than with girls. To have friends and not be alone and to have fun were also seen by men, though not by women, to be satisfied more by having boys. Women (but not men) credited sons more than daughters with creating closeness between the spouses. These findings reflect widespread social values and provide insight into the reasons for son preference in Turkey. 
TABLE 24 Contributions of daughters and sons to life values considered most important

(Percentages of respondents ascribing specified contributions to daughters, sons, and both equally)

\begin{tabular}{|c|c|c|c|c|c|c|}
\hline \multirow[b]{2}{*}{ Value } & \multicolumn{3}{|l|}{ Women } & \multicolumn{3}{|l|}{ Men } \\
\hline & $\begin{array}{l}\text { Daugh- } \\
\text { ters }\end{array}$ & Same & Sons & $\begin{array}{l}\text { Daugh- } \\
\text { ters }\end{array}$ & Same & Sons \\
\hline Financial security & 3 & 18 & 80 & 6 & 15 & 79 \\
\hline To be accepted by others & 18 & 36 & 44 & 2 & 20 & 78 \\
\hline $\begin{array}{l}\text { To have fun and entertain- } \\
\text { ment }\end{array}$ & $(22)$ & (49) & $(24)$ & (10) & $(48)$ & $(38)$ \\
\hline To be close to spouse & 11 & 42 & 47 & 34 & 40 & 26 \\
\hline $\begin{array}{l}\text { Not to be alone, to have } \\
\text { friends }\end{array}$ & 36 & 36 & 31 & $(20)$ & $(37)$ & $(46)$ \\
\hline $\begin{array}{l}\text { To achieve something, to } \\
\text { succeed }\end{array}$ & 16 & 58 & 27 & 10 & 31 & 61 \\
\hline $\begin{array}{l}\text { To be remembered after } \\
\text { death }\end{array}$ & 27 & 45 & 28 & 10 & 35 & 55 \\
\hline To have a happy home & 11 & 54 & 36 & 5 & 53 & 43 \\
\hline To carry on family name & 4 & 18 & 78 & 4 & 11 & 85 \\
\hline All values & 12 & 42 & 46 & 10 & 34 & 56 \\
\hline
\end{tabular}

NOTE: Parentheses indicate $\mathrm{N}<50$.

Another question inquired about characteristics respondents wanted to see in their children when the children grew up (Table 25). Their responses indicated different expectations from daughters and sons. Being a "good" child (i.e., having a close relationship) to parents was desired more from boys than from girls. This is a utilitarian value as it benefits the parents rather than the children and reflects a dependence on sons for old-age support when it is considered together with specific expectations of help from sons and daughters.

Another sex-differentiated quality desired in grown children was being a good spouse and having a happy marriage, desired more strongly for daughters than for sons. The homemaking role of the woman was thus considered desirable for daughters.

Although respondents wanted both sons and daughters to have an education, they desired sons much more than daughters to be successful, to "make something" of themselves-indicating that education for daughters may have been wanted for prestige or other reasons, but not necessarily for professional achievement. This finding implies that 
TABLE 25 Qualities desired in daughters and sons

(Percentages of respondents mentioning specific qualities)

\begin{tabular}{|c|c|c|c|c|c|c|}
\hline \multirow[b]{2}{*}{ Quality } & \multicolumn{3}{|c|}{ Daughters } & \multicolumn{3}{|l|}{ Sons } \\
\hline & Women & Men & $\begin{array}{l}\text { Weighted } \\
\text { total }\end{array}$ & Women & Men & $\begin{array}{l}\text { Weighted } \\
\text { total }\end{array}$ \\
\hline A GOOD DAUGHTER, SON & 16.8 & 18.6 & 18 & 27.6 & 27.8 & 28 \\
\hline $\begin{array}{l}\text { Be close to parents, confide in parents, have } \\
\text { good relationship with parents }\end{array}$ & 16.0 & 17.5 & 17 & 26.8 & 25.4 & 26 \\
\hline A MORAL PERSON & 1.5 & 3.4 & 2 & 2.2 & 6.3 & 4 \\
\hline Religious, God-fearing & 1.5 & 3.4 & 2 & 2.2 & 6.3 & 4 \\
\hline A HOMEMAKER, FAMILY MAN & 46.2 & 46.7 & 46 & 14.7 & 8.9 & 12 \\
\hline A good homemaker, able to keep house & 8.4 & 9.4 & 9 & 2.3 & 0.5 & 1 \\
\hline $\begin{array}{l}\text { A good wife, husband; a good spouse, happily } \\
\text { married; devoted to spouse }\end{array}$ & 31.6 & 32.6 & 32 & 8.7 & 5.2 & 7 \\
\hline $\begin{array}{l}\text { Married to someone who is financially stable; } \\
\text { married to someone of good social status }\end{array}$ & 11.4 & 8.8 & 10 & 2.8 & 2.6 & 3 \\
\hline $\begin{array}{l}\text { A good mother, father, parent; a good family } \\
\text { person }\end{array}$ & 4.6 & 4.2 & 4 & 3.5 & 2.4 & 3 \\
\hline HEALTH, APPEARÁNCE & 4.3 & 2.5 & 3 & 2.9 & 2.7 & 3 \\
\hline Good-looking; handsome, pretty, beautiful & 2.7 & 0.5 & 2 & 0.8 & 0.4 & 1 \\
\hline SOCIAL VIRTUES & 47.8 & 51.7 & 50 & 55.5 & 59.7 & 58 \\
\hline $\begin{array}{l}\text { Polite, well-mannered; well-bied, ladylike, a } \\
\text { gentleman }\end{array}$ & 14.2 & 14.4 & 14 & 14.6 & 11.9 & 13 \\
\hline $\begin{array}{l}\text { Friendly, able to get along well with others, } \\
\text { sociable, outgoing }\end{array}$ & 2.4 & 4.7 & 4 & 3.6 & 5.6 & 5 \\
\hline Trustworthy, reliable, dependable, loyal & 34.8 & 41.0 & 38 & 43.4 & 44.8 & 44 \\
\hline
\end{tabular}




\begin{tabular}{|c|c|c|c|c|c|c|}
\hline \multirow[b]{2}{*}{ Quality } & \multicolumn{3}{|c|}{ Daughters } & \multicolumn{3}{|l|}{ Sons } \\
\hline & Women & Men & $\begin{array}{l}\text { Weighted } \\
\text { total }\end{array}$ & Women & Men & $\begin{array}{l}\text { Weighted } \\
\text { total } \\
\end{array}$ \\
\hline ACHIE VEMENT, WORK & 55.8 & 40.0 & 48 & 80.7 & 70.5 & 76 \\
\hline Educated; can finish schooling & 39.5 & 22.3 & 31 & 54.9 & 43.3 & 49 \\
\hline $\begin{array}{l}\text { Hardworking, industrious, diligent, a good } \\
\text { worker, productive }\end{array}$ & 4.4 & 5.1 & 5 & 9.9 & 8.6 & 9 \\
\hline Successful, makes something of self & 13.9 & 11.3 & 13 & 37.5 & 30.8 & 34 \\
\hline CHARACTER, FULFILLMENT & 11.4 & 23.2 & 17 & 25.8 & 48.5 & 37 \\
\hline $\begin{array}{l}\text { Self-reliant; does not depend on others; able to } \\
\text { look after self }\end{array}$ & 4.0 & 4.1 & 4 & 5.9 & 3.9 & 5 \\
\hline Useful to society & 4.6 & 18.4 & 12 & 18.1 & 43.8 & 31 \\
\hline MISCELLANEOUS & 7.0 & 3.9 & 6 & 4.8 & 4.1 & 4 \\
\hline
\end{tabular}


parents' aspirations for girls in Turkey do not imply drastic changes in traditional sex roles.

Respondents also had different specific expectations of help from boys and girls (Table 26). They expected more financial help of various kinds from sons than from daughters but more household help from daughters. These differential expectations of material help characterized both men and women but were more pronounced among men. Relatively few respondents, particularly fathers, expected specific forms of support from daughters. This may help explain why daughters were valued less than sons for satisfying basic needs identified in Table 5. The findings also provide indirect support for hypothesis 7.

Comparisons of findings about expectations from children from the various VOC countries show clear-cut differences between U.S. and German responses on one hand and those from Turkey and such countries as Indonesia and Thailand on the other. Findings from Singapore were somewhat similar to those from the United States and West Germany; those from Korea were between the two patterns. (See Kagitcibasi, 1982a, for a detailed analysis of these country differences.) In countries where old-age security is guaranteed through social welfare programs and pension plans, grown children are not a major source of income to elderly parents, and parents do not depend on them. Together with this objective situation go values attached to independence and self-reliance. In less developed countries that do not have adequate social welfare institutions, however, old-age security is provided by the family, especially by adult children, and great value is attached to close-knit interpersonal ties and in terdependence.

The latter situation is reflected in answers to a structured VOC question about the characteristics respondents valued in a child (Table 27). Minding parents (obedience) was the most valued characteristic, whereas independence and self-reliance were the least valued. Obedience involves a dependence of the child on the parent, which in later years becomes reversed, turning into dependence of the parent on the grown child (Tables 25 and 26). These values reinforce a pattern of interdependence rather than of independence in the family.

A low level of material expectations from children appears to be associated with little differentiation between sons and daughters in such expectations. High levels of expectations from children, on the other hand, are consistent with greater sex differentiation. Males are usually 
TABLE 26 Expectations of help from sons and daughters

(Percentages of respondents, by expectation)

\begin{tabular}{|c|c|c|c|c|c|c|c|c|c|c|c|c|}
\hline \multirow[b]{3}{*}{ Expectation } & \multicolumn{6}{|c|}{ Sons } & \multicolumn{6}{|c|}{ Daughters } \\
\hline & \multicolumn{2}{|c|}{ Women } & \multicolumn{2}{|c|}{ Men } & \multicolumn{2}{|c|}{$\begin{array}{l}\text { Weighted } \\
\text { total }\end{array}$} & \multicolumn{2}{|c|}{ Women } & \multicolumn{2}{|c|}{ Men } & \multicolumn{2}{|c|}{$\begin{array}{l}\text { Weighted } \\
\text { total }\end{array}$} \\
\hline & Yes & No & $\overline{\mathrm{Yes}}$ & No & Yes & No & Yes & No & $\overline{Y e s}$ & No & Yes & No \\
\hline $\begin{array}{l}\text { Give part of their salary to you } \\
\text { when they begin working }\end{array}$ & 77 & 23 & 67 & 33 & 72 & 28 & 60 & 40 & 26 & 74 & 43 & 57 \\
\hline $\begin{array}{l}\text { Help support their brothers and } \\
\text { sisters through school }\end{array}$ & 87 & 13 & 87 & 13 & 87 & 13 & 76 & 24 & 67 & 33 & 72 & 28 \\
\hline $\begin{array}{l}\text { Contribute money in family } \\
\text { emergencies }\end{array}$ & 95 & 5 & 88 & 12 & 91 & 9 & 85 & 15 & 62 & 38 & 73 & 27 \\
\hline Help in housework & 65 & 35 & 80 & 20 & 72 & 28 & 94 & 6 & 91 & 9 & 93 & 7 \\
\hline $\begin{array}{l}\text { Support you financially when } \\
\text { you grow old }\end{array}$ & 93 & 7 & 88 & 12 & 90 & 10 & 80 & 20 & 67 & 33 & 74. & 26 \\
\hline
\end{tabular}


TABLE 27 Most and second most important qualities of a child

(Percentages of respondents ranking specified qualities)

\begin{tabular}{|c|c|c|c|c|c|c|c|c|c|}
\hline \multirow[b]{2}{*}{ Quality } & \multicolumn{3}{|l|}{ Women } & \multicolumn{3}{|l|}{ Men } & \multicolumn{3}{|c|}{ Weighted total } \\
\hline & $\begin{array}{l}\text { Most } \\
\text { important }\end{array}$ & $\begin{array}{l}\text { Second } \\
\text { most } \\
\text { important } \\
\end{array}$ & Combined & $\begin{array}{l}\text { Most } \\
\text { important }\end{array}$ & $\begin{array}{l}\text { Second } \\
\text { most } \\
\text { important }\end{array}$ & Combined & $\begin{array}{l}\text { Most } \\
\text { important }\end{array}$ & $\begin{array}{l}\text { Second } \\
\text { most } \\
\text { important }\end{array}$ & Combined \\
\hline Minding parents & 36 & 23 & 59 & 38 & 23 & 61 & 37 & 23 & 60 \\
\hline $\begin{array}{l}\text { Independence } \\
\text { and self reliance }\end{array}$ & 9 . & 10 & 19 & 12 & 6 & 18 & 10 & 8 & 18 \\
\hline $\begin{array}{l}\text { Being liked by } \\
\text { others }\end{array}$ & 6 & 11 & 17 & 8 & 21 & 29 & 7 & 16 & 23 \\
\hline Good education & 17 & 29 & 46 & 11 & 25 & 36 & 14 & 27 & 41 \\
\hline Good person & 32 & 27 & 59 & 32 & 26 & 58 & 32 & 26 & 58 \\
\hline
\end{tabular}


the breadwinners, and therefore sons are considered to be dependable sources of financial support. Among the VOC countries, differential expectations from sons and daughters were most marked in Turkey and secondly in Korea, countries in which son preference is widespread.

Son preference was very much in evidence in our findings. Eightyfour percent of respondents preferred sons, as measured by Coombs' unfolding technique (Coombs et al., 1975), whereas only 16 percent preferred daughters. ${ }^{13}$ Son preference was even more marked among men ( 92.5 percent) than among women ( 75 percent). This finding makes sense when reasons for wanting sons and daughters are considered.

Respondents who wanted a son or a daughter were asked to give their most important reasons for wanting one. As is apparent from Table 28, reasons for wanting a son were more varied than those for wanting a daughter. Those mentioned most frequently were (in order) financial and practical help while sons were young, help in old age, carrying on the family name (which was especially important to fathers), companionship and love (especially important to mothers), and religious and social obligations (especially important to fathers). Thus boys appear to satisfy many needs of Turkish parents. The most important reasons for wanting girls were for companionship and love (especially important to mothers) and for household help.

The frequency with which the companionship value of a daughter to the mother was mentioned by respondents reflects the importance of the emotional-support function of daughters for Turkish mothers. Such support from daughters and from other close women relatives and friends may help women endure their low status and hard work within the traditional family (Kagitcibasi, 1981b; Stirling, 1965; Olson-Prather, 1976).

The above findings provide support for hypothesis 7 by showing that our sample attributed different values to sons and daughters and attached particular importance to the economic value of sons. Sons

13 The percentages are for those who expressed a preference for either daughters or sons on the forced-choice item. The percentage for men is similar to those of Korean and Chinese (Taiwanese) men (92-95 percent), reflecting similar cultural values. However, in Singapore, which also has a Chinese population, the proportions were lower ( 73 percent among women, 82 percent among men), reflecting changes in social structure and norms. 
TABLE 28 Reasons for wanting a son or a daughter

(Percentages of respondents mentioning specific reasons)

\begin{tabular}{|c|c|c|c|c|}
\hline \multirow[b]{2}{*}{ Reason } & \multicolumn{2}{|l|}{ Sons } & \multicolumn{2}{|c|}{ Daughters } \\
\hline & Women & Men & Women & Men \\
\hline Help in housework & 4.6 & 3.2 & 51.1 & 52.4 \\
\hline Help and protection for other children & $0: 4$ & 0.5 & 0.0 & 0.0 \\
\hline Help in old age & 37.4 & 34.5 & 0.0 & 0.0 \\
\hline Financial and practical help & 40.8 & 41.9 & 0.0 & 0.0 \\
\hline Family name, family line & 17.3 & 33.9 & 0.5 & 2.2 \\
\hline Religious and social obligations & 11.4 & 22.6 & 0.5 & 2.8 \\
\hline Marital bond, homelife & 0.9 & 0.4 & 2.5 & 8.4 \\
\hline Companionship, love & 32.8 & 23.7 & 64.8 & 43.2 \\
\hline Play, fun, distraction & 0.0 & 0.0 & 1.6 & 0.0 \\
\hline Companion for child & 0.9 & 0.0 & 0.6 & 1.4 \\
\hline Living through children & 3.8 & 1.7 & 5.3 & 8.5 \\
\hline Achievement, power & 9.6 & 7.5 & 0.9 & 0.0 \\
\hline Fulfillment & 0.6 & 0.8 & 0.9 & 3.0 \\
\hline Less expensive & 0.0 & 0.0 & 2.5 & 1.6 \\
\hline Easier to raise & 10.6 & 8.9 & 3.1 & 1.4 \\
\hline Miscellaneous & 6.7 & 5.8 & 11.2 & 21.0 \\
\hline
\end{tabular}

were wanted because of the variety and importance of functions they served.

Nevertheless, sons were considered to entail higher emotional and economic costs than daughters. Nearly half ( 44 percent) of the respondents indicated that sons cost more economically than daughters; only 20 percent stated that daughters were more costly. The respective figures were 33 percent and 18 percent for emotional costs. Thus, sons were preferred in spite of their greater costs. Clearly, both their economic values and costs were perceived as being higher than daughters', but the former outweighed the latter.

To summarize, hypothesis 7 is supported by several of our findings. Specifically, the different contributions of sons and daughters to basic values, the desired qualities of older sons and daughters, expectations of help from sons and daughters, and reasons for wanting sons and daughters all indicate sex-role differentiation. In general, sons were found to serve more needs of the parents, and thus to enjoy greater value, than daughters. This difference in sons' and daughters' perceived values is the basis of the marked son preference in Turkey. 


\section{Woman's status, values of children, and boy preference}

Hypothesis 8 predicts that as woman's status within the family improves, economic and utilitarian values of children and boy preference decrease, whereas psychological values of children increase. Our findings related to this hypothesis are based mainly on correlations.

As stated earlier, for purposes of the study we defined woman's status within the family as consisting of her role in decision-making and also the degree of communication and role sharing between the spouses. Correlations using the index of woman's overall status (composed of the above three variables) show negative relations between woman's status and all value-of-children indices (Table 22). This finding supports the economic/utilitarian prediction of hypothesis 8 but not the psychological prediction. The psychological values used in the correlational analysis were based on factor analysis of reasons for wanting another child. For that reason, they may have been appropriate only for those who actually wanted another child, and they may not have worked very differently from the other values of children in this context.

The correlation analysis also reveals woman's family status to be negatively related to boy preference and expectation of financial help from children (Table 22). This finding supports hypothesis 8 . The overall decrease in values of children, son preference, and expectation of children's financial help with woman's improved status within the family has important implications for both women's status and family planning.

As discussed earlier, with general socioeconomic development, women's professionalism and status tend to increase. Evidence of this relationship is found in Table 22. Just as women's increased status is associated with decreased son preference on the part of women, so it also appears to be reflected in men's decreased son preference. Increased role sharing between spouses (an indicator of improved female status) is negatively associated with son preference among men (-.11). Furthermore, with development, spouses' sex-role relations become more equalitarian, and both economic/utilitarian values of children and boy preference decrease. Thus, important (causal) relationships obtain among development, intrafamily dynamics, and values of children.

Woman's status is also found to relate positively to belief in internal control; and the latter, in turn, is negatively associated with boy 
preference, economic expectations from children, and economic/ utilitarian and social/normative values of children. These patterns of relationships support hy pothesis 8 , and extending beyond it, support the general theoretical model of the study (Figure 1).

\section{Values of children and fertility}

According to hypothesis 9, values of children explain some variance in fertility even when socioeconomic development variables are held constant. Specifically, it states that economic/utilitarian values of children and boy preference are predictors of high fertility, and that psychological values of children are predictors of low fertility. This is a crucial hypothesis as it directly puts to test the theoretical model and basic assumptions of the VOC Study. The validity of the socialpsychological explanation of fertility behavior, focusing on values of children both in their own right and as intervening variables, is being tested here.

I will present here first the findings that indicate simple relationships between values of children and fertility. I will then test the hypothesis more directly, holding development variables constant.

Our analysis treated both fertility attitudes and fertility behavior as dependent variables. Indicators of fertility attitudes and behavior were parity, desired and ideal number of children, approval of birth control, whether currently using birth control, and expectation of future use. ${ }^{14}$

Table 29 presents cross-tabulations between values of children and wanting another child, for women of various parities. As expected, at all parities women who wanted more children tended to consider economic, psychological, and social values of children to be more important than did women who did not want more children. Apart from this general finding, the cross-tabulations show distinctive relationships between values of children and wanting another child for women of different parity levels. The relationship between attaching importance to economic/utilitarian values and wanting another child was most marked at a parity of two, though it held at higher parities, as well, even for those with four or more children. In contrast, women who stressed psychological values of children wanted another child if they had one or two children but not if they already had three or four. This

14 We obtained more detailed information on contraceptive use, fertility history, and attitudes, but used only the above variables to test the hypothesis. For a discussion of the rest, see Technical Note no. 5, "The Questionnaire." 
TABLE 29 Value factors, by parity and whether wanting another child

(Percentages of women rating values as important)

\begin{tabular}{|c|c|c|}
\hline Value factor and parity & Yes & No \\
\hline \multicolumn{3}{|l|}{ ECONOMIC/UTILITARIAN } \\
\hline $\begin{array}{l}\text { Parity 0 } \\
\text { Important } \\
\text { Not important } \\
\chi^{2}=.94, N=220\end{array}$ & $\begin{array}{l}70.1 \\
29.9\end{array}$ & $\begin{array}{l}51.8 \\
48.2\end{array}$ \\
\hline $\begin{array}{l}\text { Parity } 1 \\
\quad \text { Important } \\
\text { Not important } \\
\chi^{2}=3.26, N=283\end{array}$ & $\begin{array}{l}61.6 \\
38.4\end{array}$ & $\begin{array}{l}49.5 \\
50.5\end{array}$ \\
\hline $\begin{array}{l}\text { Parity } 2 \\
\quad \text { Important } \\
\quad \text { Not important } \\
\chi^{2}=28.13, p<001, N=344\end{array}$ & $\begin{array}{l}65.8 \\
34.2\end{array}$ & $\begin{array}{l}30.9 \\
69.1\end{array}$ \\
\hline $\begin{array}{l}\text { Parity } 3 \\
\quad \text { Important } \\
\text { Not important } \\
\chi^{2}=6.43, p<.02, N=325\end{array}$ & $\begin{array}{l}62.7 \\
37.3\end{array}$ & $\begin{array}{l}39.9 \\
60.1\end{array}$ \\
\hline $\begin{array}{l}\text { Parity } 4 \text { or more } \\
\text { Important } \\
\text { Not important } \\
\chi^{2}=10.98, p<.001, N=546\end{array}$ & $\begin{array}{l}89.6 \\
10.4\end{array}$ & $\begin{array}{l}53.3 \\
46.7\end{array}$ \\
\hline \multicolumn{3}{|l|}{ PSYCHOLOGICAL } \\
\hline $\begin{array}{l}\text { Parity } 0 \\
\quad \text { Important } \\
\quad \text { Not important } \\
\chi^{2}=1.33, N=220\end{array}$ & $\begin{array}{l}89.2 \\
10.8\end{array}$ & $\begin{array}{l}73.3 \\
26.7\end{array}$ \\
\hline $\begin{array}{l}\text { Parity } 1 \\
\quad \text { Important } \\
\quad \text { Not important } \\
\chi^{2}=8.00, p<.01, N=283\end{array}$ & $\begin{array}{l}68.5 \\
31.5\end{array}$ & $\begin{array}{l}50.3 \\
49.7\end{array}$ \\
\hline $\begin{array}{l}\text { Parity } 2 \\
\text { Important } \\
\quad \text { Not important } \\
\chi^{2}=8.42, p<.01, N=344\end{array}$ & $\begin{array}{l}54.6 \\
45.4\end{array}$ & $\begin{array}{l}35.0 \\
65.0\end{array}$ \\
\hline $\begin{array}{l}\text { Parity } 3 \\
\quad \text { Important } \\
\quad \text { Not important } \\
\chi^{2}=.01, N=325\end{array}$ & $\begin{array}{l}38.6 \\
61.4\end{array}$ & $\begin{array}{l}36.1 \\
63.9\end{array}$ \\
\hline
\end{tabular}


TABLE 29 (continued)

\begin{tabular}{|c|c|c|}
\hline Value factor and parity & Yes & No \\
\hline PSYCHOLOGICAL (continued) & $r$ & \\
\hline $\begin{array}{l}\text { Parity } 4 \text { or more } \\
\text { Important } \\
\text { Not important } \\
\chi^{2}=1.30, N=546\end{array}$ & $\begin{array}{l}49.3 \\
50.7\end{array}$ & $\begin{array}{l}35.8 \\
64.2\end{array}$ \\
\hline SOCIAL/NORMATIVE - & & \\
\hline $\begin{array}{l}\text { Parity } 0 \\
\text { Important } \\
\text { Not important } \\
\chi^{2}=.29, N=220\end{array}$ & $\begin{array}{l}73.8 \\
26.2\end{array}$ & $\begin{array}{l}61.9 \\
38.1\end{array}$ \\
\hline $\begin{array}{l}\text { Parity } 1 \\
\text { Important } \\
\quad \text { Not important } \\
x^{2}=.65, N=283\end{array}$ & $\begin{array}{l}53.8 \\
46.2\end{array}$ & $\begin{array}{l}47.9 \\
52.1\end{array}$ \\
\hline $\begin{array}{l}\text { Parity } 2 \\
\text { Important } \\
\text { Not important } \\
x^{2}=41.00, p<001, N=344\end{array}$ & $\begin{array}{l}55.4 \\
44.6\end{array}$ & $\begin{array}{l}17.6 \\
82.4\end{array}$ \\
\hline $\begin{array}{l}\text { Parity } 3 \\
\text { Important } \\
\text { Not important } \\
\chi^{2}=12.25, \rho<001, N=325\end{array}$ & $\begin{array}{l}56.3 \\
43.7\end{array}$ & $\begin{array}{l}27.3 \\
72.7\end{array}$ \\
\hline $\begin{array}{l}\text { Parity } 4 \text { or more } \\
\text { Important } \\
\text { Not important } \\
\chi^{2}=9.38, p<.01, N=546\end{array}$ & $\begin{array}{l}64.9 \\
35.1\end{array}$ & $\begin{array}{l}32.6 \\
67.4\end{array}$ \\
\hline
\end{tabular}

finding shows a clear difference between economic and psychological values of children in relation to fertility attitudes. Economic values appear to be closely associated with a desire for large families, whereas psychological values are not. A similar result was discussed before in connection with hypothesis 5 , which treated parity as an independent variable. The present finding seems to provide an explanatory link between two other findings. One of these, discussed in relation to hypothesis 3, was the decrease of children's economic/utilitarian value and some increase of their psychological value with development. The other, to be discussed in relation to hypothesis 11 , was an increase in the use of birth control and a decrease in parity with development. In other words, to some degree it is because economic and psychological 
values of children are affected differently by development and are also differently related to desired numbers of children that a decrease in fertility is seen with development. An explanatory refinement is thus brought into this generally observed phenomenon, commonly known as the demographic transition (Notestein, 1945; Caldwell, 1977).

In the cross-tabulations, social/normative values of children are similar to economic/utilitarian values in that, starting with a parity of two, women who placed importance on social/normative values also wanted more children. As this value comprises son preference and carrying on the family name, this finding is consistent with hypothesis 9.

Further evidence supporting hypothesis 9 is provided by the correlation matrix of background, in tervening, and dependent variables (Table 22). Economic/utilitarian and social/normative value indices were positively correlated with parity and with desired and ideal numbers of children, but they were negatively correlated with approval of birth control (-.14 and -.11 , respectively, not shown in Table 22). In contrast, the psychological value index correlated negatively with parity and desired number of children, and it had no significant correlations with the other variables. ${ }^{15}$ Thus, the psychological VOC index functioned differently from the economic and social VOCs. At high parity levels, the psychological VOC was low and the economic VOC was high. This finding provides support for hypothesis 5 and to some extent for hypothesis 9 , depending on whether parity is considered to be an independent or a dependent variable. Within the general theoretical framework of the study (Figure 1), parity is primarily a dependent variable. However, both types of relationships are meaningful, and there is most probably a mutual feedback mechanism between values of children and parity.

The findings reported thus far do not provide direct support for hypothesis 9 because socioeconomic development was not controlled in the analyses. We now consider more direct tests of hypothesis 9 using partial correlations, canonical correlations, and multiple

15 Specific correlations with values of children obtained by factor analysis and not forming indices were as follows for women: Economic values: .26 with desired number of children, . 19 with ideal number, .21 with wanting another child, .17 with boy preference, -.27 with use of birth control, and -.10 with approval of birth control. Psychological values: -.25 with parity and -.11 with birth control. 
regressions. Table 30 presents partial correlations for women, controlling for education, age, and development level (stratum and population size). With either education or development level controlled, the correlation between psychological values and desired number of children remains negative, though it decreases somewhat. Furthermore, when education is controlled, the negative correlation between psychological values and parity (shown in Table 22) becomes even more negative. On the other hand, an opposite effect is obtained for economic/utilitarian and social/normative values. Specifically, with education controlled, the correlations between those values and ideal number of children remain positive though they decrease in value. Thus, education was a contributing factor to the correlations shown in Table 22.

These findings provide direct support for hypothesis 9 . Values of children, independently of background development variables, show predicted relations with fertility variables.

Canonical correlation ${ }^{16}$ results provide further support for hypothesis 9. Interrelations among the various independent background, social/psychological variables, and values of children and their correspondence with some fertility-related dependent variables showed the following patterns. In the first variate (for women), young current age-but not early marriage-and newly urban characteristics emerge (Table 31). Psychological, economic, and opportunity costs of children have positive loadings on this variate. ${ }^{17}$ The negative loadings of economic/utilitarian values and boy preference are noteworthy. Among the fertility-related dependent variables, low parity (indicated by the negative sign) and wanting additional children are seen, but desired and ideal numbers of children have negative loadings and birth control knowledge is positively loaded. Thus, a "modern" outlook related to low fertility is apparent in this variate. The contribution of the VOCs is in the direction predicted by hypothesis 9 .

A similar and even more clear-cut pattern emerges in the first variate

16 In this technique, independent and dependent variables are delineated and each group is subjected to a factor analysis. The aim is to determine the fit between the grouped independent and dependent variables. A loading can be viewed as the correlation of a particular variable with the common variate, or as the contribution of that variable to the underlying factor.

17 The positive loading for economic values is indicated by the negative sign of the largest number of children respondent feels she can rear without financial hardship. 
TABLE 30 Partial correlations of values of children and other practice, and son preference: women

\begin{tabular}{|c|c|c|c|c|c|c|}
\hline \multirow[b]{2}{*}{ Predictor variables } & \multicolumn{3}{|c|}{ Desired no. of children } & \multicolumn{3}{|c|}{ Ideal no. of children } \\
\hline & 0 order & $\begin{array}{l}\text { Educa- } \\
\text { tion } \\
\text { con- } \\
\text { trolled }\end{array}$ & $\begin{array}{l}\text { Devel- } \\
\text { opment } \\
\text { con- } \\
\text { trolled* }\end{array}$ & 0 order & $\begin{array}{l}\text { Age } \\
\text { con- } \\
\text { trolled }\end{array}$ & $\begin{array}{l}\text { Educa- } \\
\text { tion } \\
\text { con- } \\
\text { trolled }\end{array}$ \\
\hline Psychological VOC* & -.14 & -.12 & -.08 & & & \\
\hline Social/normative VOC* & & & & .20 & & .09 \\
\hline Economic/utilitarian VOC & & & & .20 & & .10 \\
\hline Woman's status & .02 & .12 & & -.04 & -.07 & \\
\hline Exposure to mass media & -.20 & .03 & & -.14 & & .02 \\
\hline Development-population * & & & . & & & \\
\hline $\begin{array}{l}\text { Development stratum } \\
\% \text { of urban experience }\end{array}$ & & & & -.07 & -.10 & \\
\hline Age at marriage & & & & & & \\
\hline Belief in internal control & -.17 & .04 & & -.10 & .00 & \\
\hline
\end{tabular}

NOTE: Blank cell means partial correlation was not calculated.

* Index. For definition, see text, page 53.

for men (Table 32 ). In line with hypothesis 9 , the psychological value of children has a positive loading, whereas preference for a large family, economic expectation from sons, and the importance of children minding their parents have negative loadings. Awareness of childrearing costs has a positive loading. Among the fertility-related dependent variables, those with positive loadings include birth control knowledge, birth control practice, and wanting more children, the last because of low parity and young age; those with negative loadings are parity and desired number of children. Thus, similar patterns emerge for men and women, reflecting a "modern" outlook and directed toward low fertility. Psychological values of children are important in this pattern, supporting hypothesis 9 .

The second variate for women (Table 31) appears to reflect quite a different outlook, involving variables related to high fertility. Economic/utilitarian and social/normative values of children have positive loadings here, whereas the importance of children being accepted by others (a child-centered, or psychological, value) and that of the marital bond have negative loadings. Lack of concern about the costs and problems of raising a certain number of children (indicated by the positive sign) emerges here. Among the fertility-related dependent 
predictor variables with family-size desires, parity, birth control

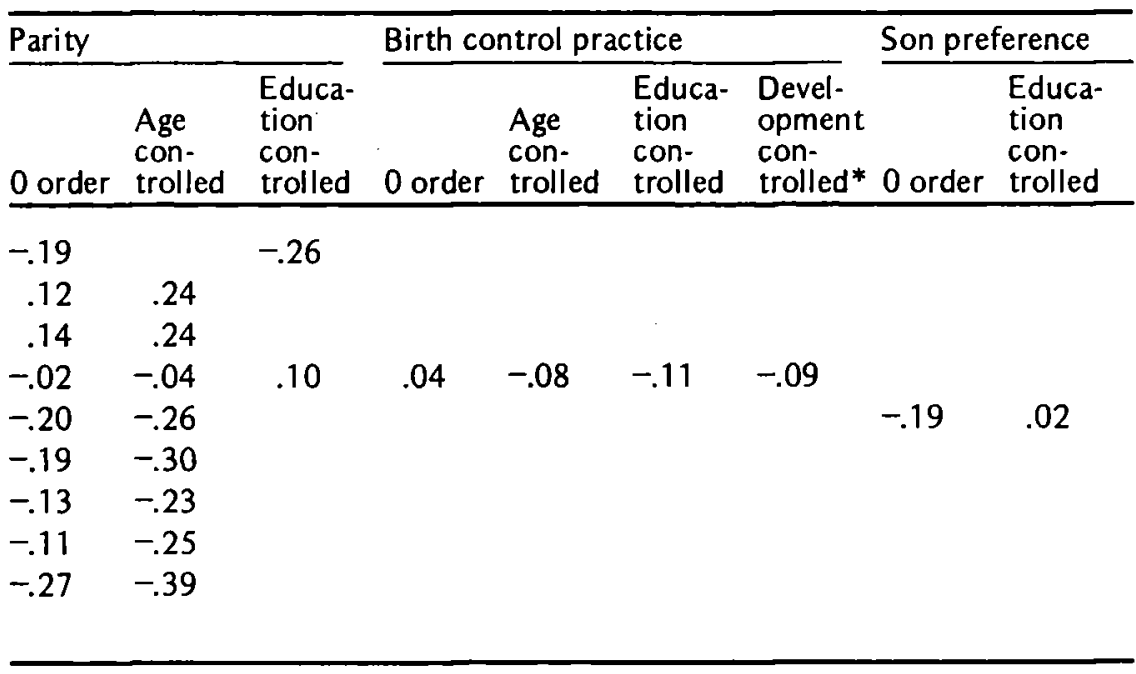

variables, both wanting more children and desired number of children have positive loadings whereas parity, birth control knowledge, and birth control practice have negative loadings. This second variate therefore appears to reflect a more "traditional" outlook, in which there is correspondence between economic and social values of children and fertility attitudes and behavior, thus supporting hypothesis 9 .

The second variate for men (Table 32 ) is similar to that for women but is less clear-cut. Here, child-related values have negative loadings. The social/normative VOC factor has a positive loading, but continuation of family line has a negative loading. Among the fertility-related dependent variables, desired number of children and wanting more children have positive loadings, yet ideal number of children has a negative loading. Together with low parity and little knowledge of birth control, they suggest a pattern of high fertility.

These canonical correlation results, especially from the first variate, provide supporting evidence for hypothesis 9 . They also fit into the general theoretical VOC framework (Figure 1).

Simple correlations, partial correlations, and canonical correlations discussed thus far have highlighted important relationships among variables. We also ran multiple regressions to determine how much of 
TABLE 31 Canonical correlations of values of children and other independent variables with family-size desires, parity, and birth control: women

\begin{tabular}{|c|c|c|c|}
\hline \multicolumn{2}{|l|}{ First variate } & \multicolumn{2}{|l|}{ Second varia te } \\
\hline Variables & $r$ & Variables & $r$ \\
\hline \multicolumn{4}{|l|}{ INDEPENDENT } \\
\hline Marriage duration & -.42 & Marriage duration & -.45 \\
\hline Age & -.27 & Economic/utilitarian VOC factor & .30 \\
\hline Education & .17 & Expectation of economic help & \\
\hline Largest number of children she & & from daughters & .25 \\
\hline could rear without hardship & -.17 & Worry caused by children & -.22 \\
\hline Opportunity cost of children & .15 & Importance of children being & \\
\hline Psychological VOC factor & .13 & popular & -.20 \\
\hline$\%$ of urban experience & -.13 & Social/normative VOC factor & .18 \\
\hline Economic/utilitarian VOC factor & -.11 & Largest number of children she & \\
\hline Urbanism & .10 & coula redi whould & $\begin{array}{r}.10 \\
-16\end{array}$ \\
\hline Son preference & -.09 & Importance of marital bond & \\
\hline Economic VOC & -.09 & & \\
\hline Importance of marital bond & .09 & & \\
\hline \multicolumn{4}{|l|}{ DEPENDENT } \\
\hline Parity & -.62 & Knowledge of birth control & -.47 \\
\hline Knowledge of birth control & .25 & Wanting additional children & .42 \\
\hline Desired number of children & -.21 & Desired number of children & .41 \\
\hline Wanting additional children. & .20 & Parity & -.39 \\
\hline Ideal number of children & -.13 & Use of birth control & -.20 \\
\hline Eigen value $=.63$ & & Eigen value $=.38$ & \\
\hline
\end{tabular}

the variance in the dependent variables could be explained by certain independent variables when other independent variables were controlled.

Regressions were run for parity, practice of birth control, expectation of future use of birth control, desired number of children, and ideal number of children. Two sets of independent variables were used. In the first, all the specific items from the questions about reasons for wanting and not wanting another child, indicating values of children, were included. In the second, indices rather than specific items were used for the values of children. Both regressions were for women. In the interest of brevity, only the regressions with indices are presented 
TABLE 32 Canonical correlation of values of children and other independent variables with family-size desires, parity, and birth control: men

\begin{tabular}{|c|c|c|c|}
\hline \multicolumn{2}{|l|}{ First variate } & \multicolumn{2}{|l|}{ Second variate } \\
\hline Variables & $r$ & Variables & $r$ \\
\hline \multicolumn{4}{|l|}{ INDEPENDENT } \\
\hline Marriage duration & -.49 & Exposure to mass media & .70 \\
\hline Psychological VOC & .27 & Age & -.34 \\
\hline Importance of marriage bond & .25 & Continuation of family line & -.34 \\
\hline Belief in internal control & -.22 & Social/normative VOC factor & .31 \\
\hline $\begin{array}{l}\text { Expectation of economic help } \\
\text { from sons }\end{array}$ & -.21 & $\begin{array}{l}\text { Importance of children minding } \\
\text { parents }\end{array}$ & -.31 \\
\hline Communication between spouses & .18 & Education & -.25 \\
\hline $\begin{array}{l}\text { Largest number of children he } \\
\text { could rear without hardship }\end{array}$ & -.18 & $\begin{array}{l}\text { Importance of children being } \\
\text { popular }\end{array}$ & -.23 \\
\hline Social/normative VOC factor & .17 & & \\
\hline $\begin{array}{l}\text { Importance of children minding } \\
\text { parents }\end{array}$ & -.17 & & \\
\hline Education & .15 & & \\
\hline Preference for large family & -.15 & . & \\
\hline \multicolumn{4}{|l|}{ DEPENDENT } \\
\hline Parity & -.64 & Desired number of children & .82 \\
\hline Wanting additional children & .27 & Ideal number of children & -.78 \\
\hline Desired number of children & -.20 & Knowledge of birth control & -.69 \\
\hline Knowledge of birth control & .19 & Wanting additional children & .38 \\
\hline Use of birth control & .12 & Parity & -.37 \\
\hline Eigen value $=.66$ & & Eigen value $=.42$ & \\
\hline
\end{tabular}

here, since the results of the two sets are quite similar. The independent variables are the indices of economic/utilitarian values, psychological values, social/normative values, development-population, marriage duration, economic expectations from children, education, husband's education, woman's family status, percentage of life spent in an urban environment, belief in internal control, exposure to mass media, boy preference, and parity. (Parity was used as an independent or a dependent variable, but not as both at the same time.) The regressions are presented in Table 33.

The regression equations delineate the effect of each independent variable on the dependent variables, controlling for the effects of the 
TABLE 33 Multiple regression analysis of VOC indices and other independent variables on parity, birth control, and desired and ideal number of children: women

\begin{tabular}{|c|c|c|c|}
\hline Dependent and independent variables & $b$ & $S E$ & $R^{2}$ \\
\hline \multicolumn{4}{|l|}{ PARITY } \\
\hline Economic/utilitarian VOC & ns & & .009 \\
\hline Psychological VOC & -.059 & $(.016)$ & .068 \\
\hline Social/normative VOC & ns & & .078 \\
\hline Development-population & -.063 & $(.020)^{*}$ & .093 \\
\hline Marriage duration & .166 & $(.009) \dagger$ & .496 \\
\hline Husband's education & -.069 & $(.022)^{*}$ & .511 \\
\hline Woman's status & .048 & $(.022)$ & .514 \\
\hline$\%$ of urban experience & -.003 & $(.001)$ & .519 \\
\hline Son preference & .078 & $(.020)^{*}$ & .534 \\
\hline Total & & & .534 \\
\hline \multicolumn{4}{|l|}{ CURRENT BIRTH CONTROL USE } \\
\hline Parity & .072 & $(.017) \dagger$ & .031 \\
\hline Economic/utilitarian VOC & -.035 & $(.011) \dagger$ & .110 \\
\hline Psychological VOC & .017 & $(.007)$ & .119 \\
\hline Social/normative VOC & ns & & \\
\hline Education & .023 & $(.009)$ & .152 \\
\hline Total & & & .163 \\
\hline \multicolumn{4}{|c|}{ EXPECTATION OF FUTURE BIRTH CONTROL USE } \\
\hline Parity & .084 & $(.019) \dagger$ & .008 \\
\hline Economic/utilitarian VOC & -.023 & $(.011)$ & .021 \\
\hline Psychological VOC & ns & & .021 \\
\hline Social/normative VOC & ns & & .021 \\
\hline Marriage duration & -.019 & $(.005) \dagger$ & .053 \\
\hline Total & & & .066 \\
\hline \multicolumn{4}{|l|}{ DESIRED NUMBER OF CHILDREN } \\
\hline Parity & .323 & $(.034) \dagger$ & .296 \\
\hline Economic/utilitarian VOC & .077 & $(.019)$ & .351 \\
\hline Psychological VOC & -.073 & $(.013) \dagger$ & .374 \\
\hline Social/normative VOC & .094 & $(.021)$ & .400 \\
\hline Development-population & -.045 & $(.016)^{*}$ & .407 \\
\hline Woman's status & .064 & $(.018) \dagger$ & 424 \\
\hline Son preference & .047 & $(.016)^{*}$ & .435 \\
\hline Total & & & .435 \\
\hline
\end{tabular}


TABLE 33 (continued)

\begin{tabular}{llll}
\hline Dependent and independent variables & $b$ & $S E$ & $R^{2}$ \\
\hline IDEAL NUMBER OF CHILDREN & & & \\
Parity & .100 & $(.029) \dagger$ & .109 \\
Economic/utilitarian VOC & .047 & $(.017)^{*}$ & .140 \\
Psychological VOC & $\mathrm{ns}$ & & .142 \\
Social/normative VOC & $\mathrm{ns}$ & & .149 \\
Marriage duration & .017 & $(.008)$ & .154 \\
Expectation of economic help & .020 & $(.009)$ & .158 \\
Son preference & .046 & $(.014)$ & .178 \\
$\quad$ Total & & & .178
\end{tabular}

NOTE: In every regression equation the three $V O C$ indices are given regardless of the significance of their $b$ values. All other $b$ values are significant at least at the .05 level.

ns-not significant.

$0 \leqslant .01$.

$\dagger \rho \leqslant .001$.

other independent variables. The greatest proportion of variance explained by the independent variables $\left(R^{2}\right)$ appears for parity (.53); the lowest $R^{2}$ is for expectation of future birth control use (.07). Between these extremes, in order of magnitude, are $R^{2} s$ for desired number of children (.44), ideal number of children (.18), and birth control practice (.16). The independent variables entering the regression equations thus contribute substantially to the explanation of variance in parity and desired number of children.

As expected, the independent variable that explains the greatest amount of variance in parity is marriage duration (first panel of Table 33). The value of children indices altogether account for .08 of the variance (.16 of the .53 explained variance). Among these, only the negative contribution of the psychological VOC is significant ( $b=$ $-.059, S E=.016$ ), and it explains .06 of the total variance in parity (.12 of the explained .53). Together with the positive contribution of boy preference, this proportion of explained variance adds up to .08 (.16 of the explained .53). In accordance with hypothesis 9 , psychological VOC has a negative effect on parity and son preference a positive one. Economic VOC, however, does not show the hy pothesized positive effect.

That the psychological value of children has a negative effect on parity, when other variables are controlled, provides support for the 
theoretical approach of the Turkish VOC Study. In other words, the existence of this value does not lead to large family size but rather has the opposite effect. This finding challenges the unidimensional conceptualization of children's value as being only economic and the assumption that a simple positive relationship exists between their value and parity.

The second panel of Table 33 presents the independent variables that explain the variance in birth control practice of Turkish respondents. Total explained variance is not high, but the greatest contribution to it is made by the VOC variables. As expected, economic/ utilitarian VOC has a notable negative effect on birth control, explaining .08 of the total variance (or .50 of the explained .16 variance). Though of lesser magnitude, psychological VOC also has a significant positive effect, as expected. These findings provide direct support for hypothesis 9 .

Only a small portion of the variance in expectation of future birth control use is explained by the independent variables entering the regression equation (third panel of Table 33). Among these, the economic/utilitarian VOC assumes importance, accounting for . 20 of the explained .07 , with a predicted negative effect on the expectation of future birth control use. This finding also supports hypothesis 9 . The positive effect of parity and the negative effect of marriage duration, due to age, are as expected.

Along with parity, VOC variables contribute significantly to the variance in desired number of children (fourth panel of Table 33). Economic/utilitarian VOC, in particular, assumes importance, accounting for .05 of the total variance (.11 of the explained .44). In accordance with hypothesis 9 , the contribution of psychological VOC to desired number of children is negative, whereas the economic/utilitarian and the social/normative VOCs have positive contributions, all three being significant at beyond the .001 level. This result shows the explanatory power of values of children over fertility attitudes even when socioeconomic variables are controlled. Together with boy preference, values related to children explain .11 of the total variance (.25 of the explained .44 ) in desired number of children.

Values related to children also assume importance in explaining ideal number of children (last panel of Table 33), as does parity. The economic/utilitarian VOC, economic expectations from children, and boy preference together explain .06 of the total variance in ideal 
number of children (.18 of the explained .33). This result supports hypothesis 9 , but the contribution of psychological VOC does not reach significance.

To summarize the regression results, the contribution of children's values to the variance in the five fertility-related variables is substantial when socioeconomic, demographic, and educational variables are controlled. Furthermore, in all regression equations the contribution of values of children surpasses that of the socioeconomic development variables. This finding provides additional support for the theoretical model of the VOC Study and generally to a social-psychological orientation to fertility. The multidimensional conceptualization of children's values and their differential relations with fertility outcome are validated by these results. Economic values and boy preference are associated with high fertility and psychological VOC with low fertility, thus supporting hypothesis 9 .

\section{Woman's status and fertility}

Hypothesis 10 predicts that as communication between spouses, role sharing, and decision sharing increase (i.e., as the woman's status within the family improves), fertility decreases. Findings related to this hypothesis are based mainly on correlations.

As indicated in the discussion of findings supporting hypothesis 8 , role sharing is negatively associated with boy preference among men $(-.11){ }^{18}$ Similarly, ideal number of children is found to decrease among men as role sharing increases (-.12). Furthermore, male decision making in the family correlates positively with desired (.14) and ideal (.23) numbers of children and negatively with birth control use $(-.37)$ and approval $(-.21)$ among men. Specific correlations for women show that communication between spouses is negatively related to desired number $(-.11)$ and ideal number $(-.18)$ of children, whereas it is positively related to birth control practice (.17). Among men the corresponding correlations are -.15 for desired number of children, -.16 for ideal number, and .22 for birth control practice. First use of birth control is earlier for men (-.25), with communication between spouses. All these correlations involving indicators of woman's status provide support for hypothesis 10 . They show that as

18 All the correlation figures given here are r's obtained from specific correlations; they are not shown in Table 22, which includes the correlations involving indices. 
relations between spouses become more equalitarian, fertility and the desire for a large family decrease.

When communication, role sharing, and decision making are combined into an index of woman's status, however, significant relations between it and fertility variables do not emerge (Table 22). This is an unexpected finding, which may be partly due to problems with index construction. ${ }^{19}$ Partial correlations utilizing the indices also show unexpected relationships (Table 30 ). When education is controlled, for example, unexpected positive correlations appear between woman's status on one hand and parity and desired number of children on the other. ${ }^{20}$ The finding that woman's status has a negative correlation with birth control practice is also unexpected, especially when age is controlled. Finally, the negative (but low) partial correlation between woman's status and ideal number of children when age is controlled is in line with hypothesis 10 , though somewhat at odds with the above findings.

Canonical correlation results for men provide some support for hypothesis 10 . Communication between spouses has a positive loading on the first variate (among the independent variables), associated with low numbers of desired and existing children and with birth control (Table 32).

Multiple regressions using the indices to explain variance in parity and desired number of children (Table 33) again do not support hypothesis 10 . Woman's status contributes positively to the variance in both parity and desired number of children. These findings are in line with the unexpected findings obtained by partial correlations, again utilizing the index of woman's status.

To summarize the findings related to hypothesis 10 , correlations show that with development and modernization, woman's status within the family increases and fertility decreases. This decrease in fertility with increased communication and role sharing between spouses and decreased male decision making appears also to be related to greater belief in internal control on the part of the woman. When

19 Responses to some of the questionnaire items may have cancelled others. Moreover, equal weighting of the responses may not have been warranted.

20 This finding may indicate that women gain in status as a result of childbearing in a traditional society such as Turkey, a situation substantiated by observations and anthropological accounts. It may also show that woman's education explains some of the relationships obtained with woman's status. 
the findings related to hypothesis 10 are considered together with those of hypothesis 8 , the following explanation appears plausible. Woman's low family status and male decision making are associated with economic and utilitarian values of children. As economic values are, in turn, associated with high fertility, they may be an explanatory link between family dynamics and fertility.

Some of the findings, however, do not support hypothesis 10 . When education and other background variables are controlled, the above hypothesized relationships do not obtain. This result indicates that woman's status may not have an effect on fertility independently of other factors. Another reason for the unexpected findings might have to do with the construction of the composite index of woman's status. In any case, hypothesis 10 can be considered to have only partial support from the data.

\section{Development and fertility}

Hypothesis 11 makes the common assertion that with developmentas indicated by education, income, occupation, development stratum, and urbanism-fertility decreases. This prediction does not involve the value of children or family dynamics variables, and therefore it does not directly support the main thesis of our study. Rather, it complements the other hypotheses and logically completes the theoretical framework of the study. It is also consistent with the demographic transition theory and with a great deal of empirical evidence. Various findings of our study, both descriptive and analytical, support the hypothesis.

First, when one examines the relationship between certain variables and place of residence (population size and development stratum), clear trends appear. It is found, for example, that among women with two children the percentage of those wanting additional children decreases with increased development at each population level. For example, 38 percent of such women in least developed rural areas wanted more children, whereas only 10 percent of those in most developed rural areas wanted more. The corresponding proportions in areas with 2,000 to 10,000 inhabitants were 47 percent (in least developed areas) and 15 percent (most developed), and in urban areas they were 32 and 14 percent, respectively $\left(\chi^{2}=25,34, p<.01, \mathrm{~N}=344\right)$.

Urban-rural differences in respondents' knowledge and use of contraception were substantial (Table 34). Differences were greater in 
TABLE 34 Parity and birth control knowledge and practice, by (Percentage of respondents)

\begin{tabular}{|c|c|c|c|c|c|c|}
\hline \multirow[b]{3}{*}{ Variable } & \multicolumn{6}{|c|}{ Development stratum } \\
\hline & \multicolumn{3}{|l|}{ Rural } & \multicolumn{3}{|c|}{ Population $2,000-10,000$} \\
\hline & $\begin{array}{l}\text { Least de- } \\
\text { veloped }\end{array}$ & $\begin{array}{l}\text { Inter- } \\
\text { mediate }\end{array}$ & $\begin{array}{l}\text { Devel- } \\
\text { oped }\end{array}$ & $\begin{array}{l}\text { Least de- } \\
\text { veloped }\end{array}$ & $\begin{array}{l}\text { Inter- } \\
\text { mediate }\end{array}$ & $\begin{array}{l}\text { Devel- } \\
\text { oped }\end{array}$ \\
\hline \multicolumn{7}{|l|}{ PARITY } \\
\hline 0 & 8.5 & 14.7 & 10.4 & 17.0 & 9.3 & 7.3 \\
\hline 1 & 11.6 & 14.8 & 18.7 & 12.5 & 14.3 & 13.8 \\
\hline 2 & 11.6 & 20.8 & 27.9 & 18.3 & 12.6 & 20.3 \\
\hline 3 & 17.9 & 19.8 & 19.9 & 14.9 & 24.2 & 19.5 \\
\hline \multirow[t]{2}{*}{4 or more } & 50.5 & 29.9 & 23.1 & 37.2 & 39.6 & 39.0 \\
\hline & \multicolumn{6}{|c|}{$\chi^{2}=209.01, p<.001, \mathrm{~N}=2,305$} \\
\hline KNOWLEDGE & $\cdot$ & & & & & \\
\hline \multicolumn{7}{|l|}{ Women } \\
\hline No & 35.2 & 26.0 & 28.0 & 25.3 & 14.0 & 25.8 \\
\hline \multirow[t]{2}{*}{ Yes } & 64.8 & 74.0 & 72.0 & 74.7 & 86.0 & 74.2 \\
\hline & \multicolumn{6}{|c|}{$\chi^{2}=99.59, p<.001, N=1,753$} \\
\hline \multicolumn{7}{|l|}{ Men } \\
\hline No & 41.7 & 18.6 & 33.3 & 18.2 & 21.7 & 20.7 \\
\hline \multirow[t]{2}{*}{ Yes } & 58.3 & 81.4 & 66.7 & 81.8 & 78.3 & 79.3 \\
\hline & \multicolumn{6}{|c|}{$\chi^{2}=47.18, p<.001, N=536$} \\
\hline \multicolumn{7}{|l|}{ PRACTICE } \\
\hline \multicolumn{7}{|l|}{ Women } \\
\hline No & 79.5 & 56.1 & 61.2 & 63.8 & 46.9 & 64.8 \\
\hline \multirow[t]{2}{*}{ Yes } & 20.5 & 43.9 & 38.7 & 36.2 & 53.1 & 35.2 \\
\hline & \multicolumn{6}{|c|}{$\chi^{2}=102.98, p<.001, N=1,261$} \\
\hline \multicolumn{7}{|l|}{ Men } \\
\hline No & 82.4 & 72.7 & 73.9 & 50.0 & 59.4 & 43.7 \\
\hline \multirow[t]{2}{*}{ Yes } & 17.6 & 27.3 & 26.1 & 50.0 & 40.6 & 56.2 \\
\hline & \multicolumn{6}{|c|}{$\chi^{2}=40.09, p<.001, N=353$} \\
\hline
\end{tabular}

knowledge than in practice, however, indicating that knowledge of birth control methods does not automatically lead to use.

Correlational analysis using a development-population index (Table 34) reveals that both knowledge and use of contraception increased with development. However, a linear progression does not appear, indicating that the index may not be completely unidimensional. 
development stratum and rural-urban residence

\section{Urban}

Least de- Inter- Develveloped mediate oped

$\begin{array}{llll}16.3 & 16.8 & 11.2 & 14.1 \\ 10.4 & 16.1 & 23.0 & 22.9 \\ 14.2 & 22.3 & 28.2 & 30.1 \\ 17.4 & 19.9 & 15.5 & 18.0 \\ 41.6 & 24.9 & 22.0 & 14.9\end{array}$

$\begin{array}{ll}13.6 & 14.9\end{array}$

86.4

85.1

7.5

92.5

6.9

93.1

81.1

6.7

93.3

9.6

90.4

31

69

18

$\chi^{2}=33.76, p<.001, N=1,523$

$22.8 \quad 18.9$

77.2

81.1

$\begin{array}{ll}48.8 & 50.9\end{array}$

33.0

67.0

43.1

$\begin{array}{ll}62 & 52 \\ 38 & 48\end{array}$

$\chi^{2}=11.15, p<001, N=1,092$

60.6

68.2

46.6

31.8

53.4
36.5

63.5
$32 \quad 16$

$68 \quad 84$

$\chi^{2}=15.43, p<.001, N=482$
39.4

31.85 .4

$$
\begin{array}{lc}
72 & 60 \\
28 & 40 \\
\chi^{2}=4.82, & p<.05, N=311
\end{array}
$$

There may be a development overlap, especially between the rural (population less than 2,000) and the 2,000-10,000 population categories.

As reported in the section on respondent characteristics, there were differences in parity between rural and urban areas, the respective means being 3.16 and 2.58 children. Correlation analysis by 
development-population level also shows substantial differences in parity, though again the progression is not linear (Table 34).

Various indicators of development and modernization show significant correlations with fertility variables among women (Table 22). As a modern orientation, for example, belief in internal control is negatively associated with parity, desired and ideal number of children, . and boy preference. Similarly, exposure to mass communication (considered a modernizing influence), education, and husband's education are negatively correlated with actual, desired, and ideal numbers of children and with boy preference, whereas they show positive relations with birth control use (as well as with woman's status and belief in internal control). Mass communication exposure and education are also positively correlated with approval of birth control (the correlations being .16 and .10, respectively, not shown in Table 22). Furthermore, development variables such as the development-population index, urban standing, percentage of urban experience, and income show the expected relations with the above-mentioned fertility variables. These findings accord with the general theoretical framework of the study and provide support for hypothesis 11 .

The negative correlations of parity with exposure to mass media, development stratum, urban standing, and percentage of urban experience become more substantial when age is controlled (Table 30). Similarly, with age controlled there is an intensification of the negative correlation between development stratum and ideal number of children.

The canonical correlation results also support hypothesis 11 (Tables 31 and 32). For both men and women, education and, for women, urbanism have loadings in the first variate, which captures the common dimension of low-fertility desires and knowledge or use of birth control. Correspondingly, education for men is negatively loaded in the second variate involving high-fertility desires and lack of birth control knowledge. The contribution of development variables, however, is less than that of values of children.

The multiple regression analyses also provide support for hypothesis 11. The development-population index, percentage of urban experience, and husband's education contribute negatively to the variance in parity (Table 33). Similarly, development stratum and size of population have a negative effect on desired number of children, and education has a positive effect on contraceptive use. 
Many of our findings thus show the expected relationships between development and fertility. These results are consistent with evidence that has emerged from other studies around the world.

\section{SUMMARY AND CONCLUSIONS}

The main purpose of this study was to test the validity of a socialpsychological model of fertility behavior within the Turkish sociocultural context. According to the model, among the factors that influence fertility behavior are the values-positive and negative-that people ascribe to children. The model and the working hypotheses derived from it were tested with data from a representative sample of the Turkish population.

The model, which assumes multiple causality of individual behavior, contains four interrelated clusters of variables. The first is a group of independent background variables including development level (or stratum) of place of residence, socioeconomic status of the person, and his or her demographic characteristics. These economic, socialstructural, and demographic factors are commonly included in studies of population dynamics. We hypothesized them to be influential in this study, and the findings generally supported this expectation. A major characteristic of the model, however, is its inclusion of two clusters of social-psychological variables that are assumed to be influenced by the above background variables and, in turn, to influence consequent fertility variables. One of these two is a group of individual and interactional (interpersonal) social-psychological variables. The other, which is the focal point of the study, is the perceived value of children. The main proposition of the study is that these socialpsychological variables, in addition to the background variables, influence fertility. Eleven hy potheses reflecting this view were tested and supported by the findings. The fourth cluster of variables includes the dependent fertility attitudes and behavior that the study attempted to explain.

The findings showed that socioeconomic and cultural factors affect the perceptions, values, and attitudes of people, and are reflected in relations between spouses. Values, perceptions, and attitudes, in turn, as social-psychological mechanisms, affect fertility behavior. The hypotheses predicting changes in values associated with children as socioeconomic conditions change and those about the relations between values and fertility were supported by the cross-sectional data. 
The findings have also thrown light on various characteristics of Turkish society. In the areas of family dynamics, sex roles, social change, attitudes, 'and values related to children, our findings concur with and extend previous findings from anthropological and other social science research. For example, previous research results pointing to the inferior status of women in traditional Turkish society are supported by the VOC findings, which indicate low levels of sex-role sharing and communication between spouses as well as prevalent male decision making. The dependent status of women is reflected in the importance women in the sample attached to being close to their spouse; in the salience of "strengthening the marital bond" as a reason for them not to want fewer than a desired number of children; and in one of their mean reasons for wanting more children, "to bring the spouse closer." Furthermore, whether a woman worked or not did not affect her status substantially. Rather, the nature of her occupation, or level of professionalism (including education) appears to have been the key determinant of status. That most Turkish women accept their homebound, dependent role was substantiated by the differential expectations women in the VOC sample had of occupational achievement from their sons and daughters, the latter being confined mainly to homemaking.

Women's dependency appears to be an inherent part of a general pattern of interdependent relationships appearing first as dependency of the child on the parents and later as the reversal of this relationship. The most desired qualities of children identified by VOC respondents reflected this situation. These qualities were obeying the parents while young and being loyal to parents as adults. The old-age security value of children to parents plays a key role within this culturally endorsed pattern of interdependence. The great importance of this value underlies parents' reliance on children for basic needs that are not yet met through formal institutional measures such as old-age pensions. Differences between respondents from least and most developed areas of Turkey suggest that with social change and development profound changes take place in these traditional family relationships and in people's values, as posited by our hypotheses.

Thus, various findings of the.VOC Study have helped to define the socio-cultural context in which the value of children and fertility can be understood. The hypothesized relationships fit in to this general human framework. 
To summarize the results of the analyses directed at testing the hypotheses, it can be stated, first, that the new model proposed for explaining fertility behavior found support in the VOC data. This social-psychological model posits that the perceived value of children is a microlevel causal link in the observed relationship between socioeconomic development and fertility decline, described at the macrolevel by demographic transition theory. Although the concept of the value of children is seen in other theoretical approaches to fertility also, in our approach it achieves greater explanatory power because of its multidimensional conceptualization and more precise assessment. Our findings indicate that with socioeconomic development and especially with education, the economic value of children decreases whereas their psychological value increases, at least in relative terms. The total perceived value of children probably does not diminish much, or at least not so much as their economic value. However, because children's economic value is cumulative with increased family size whereas their psychological value is not (and, in fact, is negatively associated with parity), the decrease in their economic value and increase in their psychological value imply lowered fertility. In other words, fertility decreases with development because economic and psychological values of children are differentially affected by development and are differentially related to desired family size. Two conclusions follow:

1. Decreasing fertility is not an automatic outcome of socioeconomic development. Rather, development is reflected in changing intrafamily relations, individual values, and needs. As the basic needs of people are satisfied in new ways, their motivations and perceptions change, with the result that they attribute different values to their children.

2. This change in the values attributed to children implies more a qualitative change than a drastic reduction of children's value. It is a natural outcome of children's now satisfying psychological needs rather than economic (for example, old-age security) needs of parents.

This explanation of fertility decline is different from that of the economic approach. The latter focuses exclusively on the economic value of children, predicting a decrease in children's total value with development (see, for example, Youssef, 1978:95, 97). Such a prediction is not borne out by our findings. The same prediction of fertility decline with development is made in both approaches but for different theoretical reasons. 
It appears that in socioeconomic con texts where children's economic value assumes great importance, there is also widespread son preference. This is because sons, both while they are young and as the main future breadwinners, satisfy parents' need for material support and old-age security. In such families the dependent, inferior status of the uneducated woman is also seen. Furthermore, we found this pattern of interpersonal relations and corresponding values to be associated with high parity. The reverse pattern, involving greater salience of psychological values and less salience of economic values, less son preference, and egalitarian intrafamily relations, results in low parity.

In order to understand why social structure and development affect fertility, it is necessary to inquire into the needs that assume importance to people in particular social-structural contexts and how these needs are reflected in social and individual values and behavior. With development, changing needs and motivations reinforce the emergence of different values and resultant behavior. Values attributed to children appear to be a key link in this causal chain from socioeconomic development to fertility decline. This study has sought to understand this process of change in Turkish society.

\section{POLICY IMPLICATIONS}

The rate of population growth in Turkey has decreased somewhat from what it was in the 1950 s and 1960 s, but it is still 2.2 percent per annum. The present population of about 45 million is projected to reach between 67 and 74 million in the year 2000 (Tuncer, 1977:38). Slowing down the rate of population growth and facilitating widespread adoption of contraception are official government policy objectives. Nevertheless, Turkey is in its fourth five-year development plan period; and even the objectives of the second five-year development plan have not been realized in the area of population. This is partly a result of the scope and complexity of the problem of rapid population growth. The solution to the problem probably requires the efficient and widespread implementation of a carefully planned population policy, carried out in coordination with integrated health services and universal education. Even such thorough policy implementation may fall short of its target without concomitant socioeconomic development and industrialization, social security systems, and educational and occupational opportunities for women-i.e., major 
structural changes in Turkish society. Here my aim is not to delineate the characteristics of such comprehensive changes, but rather to suggest what relevance the findings of the Turkish VOC Study might have for change.

Understanding the value of children to parents is important in and of itself. Such understanding throws light on the place and role of the child in the family and society, and on family dynamics. It thus provides insight into an important and little known aspect of human behavior. For this reason, studies of the place and role of the child within the family can provide a rich source of information for behavioral sciences and policies directed at human welfare. In addition, understanding the value of children to prospective parents has practical implications for population education and population policy. Only if the perceived positive values of children and the motivations of target groups are known, is it possible to influence those motivations in desired ways. Knowledge about the perceived costs of children can be used to create or support public opinion favorable to low fertility. Knowledge about the values and costs of children can help policymakers modify the cost-benefit balance of having large or small families.

One of the main findings of the Turkish VOC Study was the difference in nature and function between economic and psychological values associated with children. Economic and utilitarian values were associated with having many children, whereas the psychological values were compatible with small families. This knowledge can be used in communication programs designed to encourage lower fertility. Such programs, for example, can emphasize children's contribution to adults' happiness and pleasure, but also point out that a few children can satisfy parents' psychological needs better than many children, that the worries of raising many children get in the way of enjoying them, and that childrearing should be a joy, not a burden. Such communication may help dissociate children's value from the notion that more children are necessarily more desirable than fewer.

A similar dissociation might be attempted even for economic values, in particular the old-age security value of children, through the concept of the "quality" child. Communication programs might, for example, suggest that one or two well-educated, successful children can provide a better guarantee of old-age support to their parents than many poor, uneducated children. Similarly, social or normative values, 
associated with children, such as their conferring adult status on their parents, can also be dissociated from large numbers of children, for only one or two children can provide such status, as evidenced by our data.

Continuation of the family name, and having sons, however, might be more difficult to ensure with one or two children. The multiplicity of needs satisfied by sons in a traditional society makes son preference quite resistant to change. It is the core of a pattern of dependent interpersonal relations among families, a pattern involving low education and low status of women, child labor, and reliance on adult male children for old-age support. This pattern can be altered only by the introduction of viable alternatives to children, particularly sons, as providers of economic security, for their security value appears to be central to large-family preferences. Provision by the government or employers of old-age security benefits and unemployment and health insurance would be the most effective alternative. Owing to economic difficulties, however, the viability of such measures seems doubtful at least for some time to come. Increasing educational and occupational opportunities for women would be another means for providing alternatives to children. Education and formal employment would. increase women's status in the family, enabling them to participate in family decision-making, to be less dependent on their husbands and sons for support, and to limit their fertility through the use of contraception. Time spent on education and job would also interfere with having many children by raising women's age at marriage and the opportunity costs of children.

Just as population education can teach people that positive values. of children can be satisfied by small numbers of children or alternative ways of satisfying basic needs, so can it be used to heighten awareness of the costs of children. Our. findings indicate that children entail a substantial economic burden to their parents. Population communication could emphasize this fact. Greater awareness of the opportunity costs of children could be created, especially among working women, and could be more closely associated with numbers of children. In addition, since the first child imposes the greatest opportunity cost, communication efforts could encourage couples to postpone childbearing, as well as to have fewer children. Similarly, the increased emotional cost of children with larger family sizes could be stressed. Not only the perceived costs, but also the actual costs, of children 
could be increased, through taxation and similar measures. However, the latter type of policy runs the risk of unjustifiably penalizing children and poorer parents.

It is crucial to reach young adults before they have children or while their families are small. Both formal and informal education for parenthood through schools, mass media, and adult education institutions assumes importance. Most parents become aware of the problems of having too many children after they have had them. Every attemptshould be made, therefore, to reach them before it's too late.

The values of children revealed by the VOC Study can thus be used in communications designed to modify some of those values and the fertility patterns they foster. Changes in the social structure that would affect the needs underlying these values would have the most fundamental and long-lasting effect on fertility values, however. Furthermore, value changes would create new demands that would have to be met with better heal th services and universally available contraceptive technology. Indeed, value changes have already begun to occur in Turkey, as evidenced by the VOC sample's moderate family-size preferences. The availability of comprehensive health services and universal education would give impetus to these new values and would lower both infant mortality and fertility.

The most effective population policy is likely to be one that has as its objective the health and welfare of the child, the mother, and the family. The VOC Study of intrafamily dynamics, perceptions, and values has focused on the individual and on the motivations underlying the individual's behavior. The results of the study shed light on the interrelations among Turkish parents and their children, and in doing so suggest population policy measures directed toward human welfare. 


\section{REFERENCES}

Abadan-Unat, Nermin

1976 Implications of migration on emancipation and pseudoemancipation of Turkish women. Paper presented at Wellesley College Conference on. Women and Development, June 2-6.

Arnold, Fred, Rodolfo A. Bulatao, Chalio Buripakdi, Betty Jamie Chung, James T. Fawcett, Toshio Iritani, Sung Jin Lee, and Tsong-Shien Wu

1975 The Value of Children: A Cross-National Study. Vol. 1, Introduction and Comparative Analysis. Honolulu: East-West Center.

Amold, Fred, and James T. Fawcett

1975 The Value of Children: A Cross-National Study. Vol. 3, Hawaii. Honolulu: East-West Center.

Berelson, Bernard

1964 Turkey: national survey on population. Studies in Family Planning 1(5).

1973 The value of children: a taxonomical essay. In The Population Council Annual Report 1972, pp. 17-27. New York: Population Council.

Boserup, Ester

1970 Woman's Role in Economic Development. New York: St. Martin's Press.

Bulatao, Rodolfo A.

1975 The Value of Children: A Cross-National Study. Vol. 2, The Philippines. Honolulu: East-West Center.

1979a Further Evidence of the Transition in the Value of Children. Papers of the East-West Population Institute, No. 60-B. Honolulu: EastWest Center.

1979b On the Nature of the Transition in the Value of Children. Papers of the East-West Population Institute, No. 60-A. Honolulu: East-West Center.

Bulatao, Rodolfo A., and Fred Arnold

1977 Relationships between the value and cost of children and fertility: cross-cultural evidence. In Proceedings of the IUSSP International Population Conference, Mexico, Vol. 1.

Buripakdi, Chalio

1977 The Value of Children: A Cross-National Study. Vol. 4, Thailand. Honolulu: East-West Center. 
Caldwell, John C.

1977 Towards a restatement of demographic transition theory. In John C.

Caldwell, ed., The Persistence of High Fertility, pp. 25-123.

Family and Fertility Change, Series 1, Part 1. Canberra: Australian National University.

Cavdar, Tevfik

1975 Sample design. In Arjun Adlakha, ed., Proceedings of the Seminar on the Design of the Turkish Demographic Survey. Chapel Hill:

University of North Carolina.

Coombs, Clyde H., Lolagene C. Coombs, and Gary H. McClelland

1975 Preference scales for number and sex of children. Population

Studies 29(2):273-98.

Couch, A., and K. Keniston

1960 Yeasayers and naysayers: agreeing response set as a personality variable. Journal of Abnormal and Social Psychology 60:151-74.

Duben, Alan

1982

The significance of family and kinship in urban Turkey. In

Cigdem Kagitcibasi, ed., Sex Roles, Family and Community in

Turkey. Turkish Studies Series. Bloomington: Indiana University.

Esmer, Yilmaz

1979 Classifying the value of children: an empirical approach. Unpublished monograph. East-West Center, Honolulu.

Fallers, L., and M. Fallers

1976 Sex roles in Edremit. In Jean G. Peristiany, ed., Mediterranean Family Structure, pp. 243-60. Cambridge: Cambridge University Press.

Fawcett, James T.,

1977 The value and cost of children: converging theory and research. In Lado T. Ruzicka, ed, The Economic and Social Supports for High Fertility, pp. 91-114. Canberra: Australian National University, Department of Demography.

Fawcett, James T., ed.

1972 The Satisfactions and Costs of Children: Theories, Concepts, Methods. Honolulu: East-West Center.

Hoffman, Lois W., and Martin L. Hoffman

1973 The value of children to parents. In James T. Fawcett, ed., Pychological Perspectives on Education, pp. 19-76. New York:

Basic Books. 
Iritani, Toshio

1979 The Value of Children: A Cross-National Study. Vol. 6, Japan. Honolulu: East-West Center.

Kagitcibasi, Cigdem

1970 Social norms and authoritarianism: a Turkish-American comparison. Journal of Personality and Social Psychology 16:444-51.

1973 Psychological aspects of modernization in Turkey. Journal of Cross-Cultural Psychology 4:157-74.

1975a Modernity and the role of women in Turkey. Bogazici University Journal 3:83-93.

1975b Value of children. Paper presented at the Second Demographic Conference, Cesme, Izmir.

1976 The value of children in Turkey: perspectives and preliminary findings. Paper presented at IUSSP Seminar on Household Models of Economic-Demographic Decision Making, Mexico City.

1979 Effects of employment and children on women's status and fertility decisions. Paper presented at International Development Research Centre Workshop on Women's Roles and Fertility, Ottawa, June 25-27.

1981a Assessment of values and attitudes in the study of fertility: problems and prospects. Paper presented at Conference on Human Assessment and Cultural Factors, Queen's University, Kingston, Ontario, August 16-21.

1981b Cocugun Degeri: Turkiye'de degerler ve dogurganlik (Value of the Child: Values and Fertility in Turkey). Istanbul: Bogazici University Publications.

1982a Old age security value of children: cross-national socioeconomic evidence. Journal of Cross-Cultural Psychology 13(1):29-42.

$1982 \mathrm{~b} \quad$ Value of the child, women's role and fertility in Turkey. In Nermin Abadan-Unat, ed., Women in Turkish Society. Leiden: Brill.

Kagitcibasi, Cigdem, and Yilmaz Esmer

1980 Development, value of children and fertility: a multiple indicator approach. Report prepared for the Middle East Awards Program, Bogazici University.

Kandiyoti, Deniz

1974 Some social-psychological dimensions of social change in a Turkish village. The British Journal of Sociology 25(1):47-62.

1977 Sex roles and social change: a comparative appraisal of Turkey's women. Signs: Joumal of Women in Culture and Society 3(1). 
Kazgan, Gulten

1982 Women's labour force participation, professional distribution, educational level and socio-economic status in Turkey. In Nermin Abadan-Unat, ed., Women in Turkish Society. Leiden: Brill.

Kiray, Mubeccel B.

1976 Changing roles of mothers: changing intra-family relations in a Turkish town. In Jean G. Peristiany, ed., Mediterranean Family Structure, pp. 261-71. Cambridge: Cambridge University Press.

Lee, Sung Jin

1979

The Value of Children: A Cross-National Study. Vol. 7, Korea. Honolulu: East-West Center.

Magnarella, Paul J.

1974 Tradition and Change in a Turkish Town. New York: Wiley.

Mauldin, W. Parker, and Bernard Berelson

1978 Conditions of fertility decline in developing countries, 1965-75. Studies in Family Planning 9(5):89-148.

Meeker, Michael E.

1976 Meaning and society in the Near East: examples from the Black Sea Turks and the Levantine Arabs. International Journal of Middle East Studies 7:243-70, 338-423.

Notestein, Frank W.

1945 Population: the long view. In Theodore W. Schultz, ed., Food for the World, pp. 36-57. Chicago: University of Chicago Press.

Olson, Emelie A.

1981 Duofocal family structure and an altemative model of husbandwife relationships. In Cigdem Kagitcibasi, ed., Sex Roles, Family and Community in Turkey. Turkish Studies Series. Bloomington: Indiana University.

Olson-Prather, Emelie A.

1976 An alternative model of the family in Turkey. Chapter 6 in "Family planning and husband-wife relationships in contemporary Turkey."Ph.D. dissertation, University of California at Los Angeles.

Ozbay, Ferhunde, and Frederick C. Shorter

1970 Turkiye'de aile planlamasi uygulamalarinda 1963 ve 1968 yillari arasinda gorulen degismeler (Changes in family planning applications in Turkey between 1963 and 1968). Hacettepe Sosyal ve Beseri Bilimler Joumal 2(2). 
Peabody, Dean

1966 Authoritarianism scales and response bias. Psychological Bulletin 65:11-23.

Population Reference Bureau

1976 World Population Data Sheet. Washington, D.C.

Prime Ministry State Institute of Statistics

1979 Statistical Yearbook of Turkey, 1978. Ankara.

Rotter, J.B.

1966 Generalized expectancies for internal versus external control of rein forcement. Psychological Monographs 80(1):1-28.

Shorter, Frederick C.

1968 Information on fertility, mortality and population growth in Turkey. Population Index 34:14-15.

Sistrunk, Frank, and John W. McDavid

1971 Sex variable in conforming behavior. Journal of Personality and Social Psychology 17:200-207.

Stirling, Paul

1965 Turkish Village. London: Weidenfeld and Nicolson.

Timur, Serim

1972 Turkiye'de aile yapisi (Family Structure in Turkey). Publication D-15. Ankara: Hacettepe University.

1977 Demographic correlates of woman's education. In Proceedings, Intemational Union for the Scientific Study of Population 18th General Conference, Mexico City, 8-13 August, pp. 463-96. Liège: IUSSP.

Tuncer, Baran

1976 Ekonomik gelisme ve mufus (Economic Development and Population). Publication D-20. Ankara: Hacettepe University.

1977 Gelecekte Turkiye nufisu ve ekonomisi (Future Turkish Population and Economics). Ankara: Turkiye Kalkinma Vakfi Publication.

Wu, Tsong-Shien

1977 The Value of Children: A Cross-National Study. Vol. 5, Taiwan. Honolulu: East-West Center.

Youssef, Nadia $\mathrm{H}$.

1978 The status and fertility patterns of Muslim women. In Lois Beck and Nikki Keddie, eds., Women in the Muslim World, pp. 69-99. Cambridge, Mass.: Harvard University Press. 
CURRENT STUDIES ON THE VALUE OF CHILDREN is a SUbseries Of PAPERS OF THE EAST-WEST POPULATION INSTITUTE. It presents analyses of data from the Value of Children project, a cross-national study of parents' perceptions of the satisfactions and costs of children, and findings from similar studies. A description of the project may be found in the Editor's Foreword of Paper 60-A, On the Nature of the Transition in the Value of Children.

All papers in Current Studies will be assigned the number 60 , to indicate that they are part of Papers of the East-West Population Institute. The serial number for each subseries paper, however, will include a letter suffix (A, B, etc.) designating its sequence in the subseries.

Editor: James T. Fawcett

\section{PREVIOUS PAPERS IN THE SUBSERIES}

60-A On the nature of the transition in the value of children, by Rodolfo A. Bulatao, March $1979, x v i+104$ pp.

60-B Further evidence of the transition in the value of children, by Rodolfo A. Bulatao, November 1979 , vii $+84 \mathrm{pp}$.

60-C The value of children to Australian, Greek, and Italian parents in Sydney, by Victor J. Callan, December 1980 , vii +60 pp.

60-D Two are not enough: the value of children to Javanese and Sundanese parents, by Russell K. Darroch, Paul A. Meyer, and Masri Singarimbun, February 1981, viii + $86 \mathrm{pp}$. 
THE EAST-WEST CENTER-officially known as the Center for Cultural and Technical Interchange Between East and West-is a national educational institution established in Hawaii by the U.S. Congress in 1960 to promote better relations and understanding between the United States and the nations of Asia and the Pacific through cooperative study, training, and research. The Center is administered by a public, nonprofit corporation whose international Board of Governors consists of distinguished scholars, business leaders, and public servants.

Each year more than 1,500 men and women from many nations and cultures participate in Center programs that seek cooperative solutions to problems of mutual consequence to East and West. Working with the Center's multidisciplinary and multicultural staff, participants include visiting scholars and researchers; leaders and professionals from the academic, government, and business communities; and graduate degree students, most of whom are enrolled at the University of Hawaii. For each Center participant from the United States, two participants are sought from the Asian and Pacific area.

Center programs are conducted by institutes addressing problems of communication, culture learning, environment and policy, population, and resource systems. A limited number of "open" grants are available to degree scholars and research fellows whose academic interests are not encompassed by institute programs.

The U.S. Congress provides basic funding for Center programs and a variety of awards to participants. Because of the cooperative nature of Center programs, financial support and cost-sharing are also provided by Asian and Pacific governments, regional agencies, private enterprise, and foundations. The Center is on land adjacent to and provided by the University of Hawaii.

THE EAST-WEST POPULATION INSTITUTE, established as a unit of the East-West Center in 1969 with the assistance of a grant from the Agency for International Development, carries out multidisciplinary research, training, and related activities in the field of population, placing emphasis on economic, social, psychological, and environmental aspects of population problems in Asia, the Pacific, and the United States. 